\title{
Current Crystallographic Books 1970 through 1981
}

\author{
EDITED BY JOHN H. ROBERTSON \\ School of Chemistry, University of Leeds, England
}

The previous Crystallographic Booklist, edited by Helen Megaw, was published for the IUCr in 1965;* supplements were published in 1966 and 1972, the latter in J. Appl. Cryst. 5 (April, 1972). The present Booklist is an addition to, rather than a replacement of, that of Mcgaw.

The format of this Booklist, different from its forerunners, is intended to maximise convenience and efficiency for the user - not so much to be definitive, but rather to have the greatest practical value.

Crystallography is a large and interdisciplinary field, with many near-neighbour fields. There are many books now, on many different topics. However, the researcher, teacher, or student, who is looking for suitable books, has usually only one subject area, or perhaps three or four related ones in mind at any one time. Accordingly, the 1200 or so entries in this list are divided up into about 30 identifiable subject areas, each of which is then of roughly uniform material and of manageable size. One admitted drawback of this system is that some books, inevitably, are such as to be associated with two (or more) subject areas; here, this difficulty is met simply by the duplication of all such entries. The slightly increased volume of the resulting list is a small price to pay, we believe, for the basic convenience of these segregated subject areas. Within these subject categories, the books are listed alphabetically by author because, within any one area (with the exception of Tabulations, perhaps), books are far more commonly referred to by author than by title. The layout which we have adopted is very compact and the device of differing typefaces is used to enable the user to scan up and down the columns quite easily and efficiently, either for authors, or for TItLEs, just as desired.

For each entry in this Booklist, the amount of author information is intended to be enough for the user to locate that book in a library or to order it from a bookseller. Hence the ubiquitous initials. The name of the publisher is given for those who wish to purchase but addresses are not normally given since most booksellers usually know these, except in special cases. The date of publication is always given because this is an important detail in a rapidly moving subject such as ours. (This itself is the main reason for the restriction of this Booklist to the past decade.) Whenever a book has been reviewed in one or other of the IUCr journals (this is so for about half of all titles), the reference to that review is given; since we are referring to these IUCr journals only, we have used the simple abbreviations, A, B and J for the Acta Cryst. sections A and B, and J. Appl. Cryst., respectively. Finally, there are, scattered here and there, various comments on the books which are essentially personal ones (for which the IUCr cannot be held responsible), which it is hoped will be helpful to the users of this compilation.

*Prior to Helen Megaw's Booklist (which contained about 1000 entries) a still earlier one was edited by Judith Milledge and Arne Magnéli.
Acknowledgements It was the IUCr Commission on Journals which initiated the production of this Booklist; members of that Commission have contributed useful suggestions as well as titles. The Commission on Crystallographic Teaching (which initiated the first Booklist) was also much interested and, following the XIIth Congress at Ottawa, contributed a great deal of material. It was the suggestion of this Commission that the boundaries of the Book list should be widened to include books in any language (i.e. not be limited to the four IUCr official languages). This move delayed production somewhat but has significantly enhanced the international flavour of the resulting list. Contributions were received from all members of that Commission and its Consultants, especially Professor H. von Philipsborn (of Regensburg University, Federal Republic of Germany), who organised this exercise, and most notably from Dr Barbara Oleksyn (of the Jagiellonian University, Krakow, Poland), who submitted by far the largest number of titles from Eastern Europe, including the USSR.

The subject areas ('key words') used are:

1. Crystal Growth

2. Crystal Physics/Physics of Condensed Matter

3. Defects/Faults/Impurities

4. Diffraction Theory

5. Electron Diffraction

6. Electron Microscopy

7. General Crystallography

8. History

9. Industrial Crystallography/Metals/X-ray Spectrometry

10. Liquid Crystals

11. Materials and their Properties/General Materials Science

12. Materials/Electronics/Devices/Semiconductors

13. Materials as Electrolytes/Fast Ionic Conductors

14. Materials of Low Dimensionality

15. Mathematics/Computing

16. Methods for Solving Structures

17. Minerals

18. Miscellaneous

19. Molecular Structures

20. Neutron Diffraction/Scattering

21. Optical Microscopy

22. Phases/Phase Transformation and Polycrystalline Diffraction

23. Polymers

24. Proteins/Macromolecules/Biological

25. Solid-State Chemistry/Crystal Chemistry/General Crystal Structures

26. Student-Oriented Texts/Books for Students

27. Surfaces

28. Symmetry

29. Tabulations/Data/Bibliography 


\section{Crystal Growth}

Bardsley, W. et al. (Eds.): Crystal GROWTH: A TUTORIAL APPROACH. (N. Holland, 1979). Substance of the summer school of 1977; a useful text, though unattractively produced. Review in J14, 155.

Blom, G. M. et al. (Eds.): Liquid phase kPITAXY. (N. Holland, 1974). Review in J8, 697.

Bourdon, J. (Ed.): Growth AND PROPJRTIFS OF METAL Clusters. (Elsevier, 1980). Conf. proc.; applications to catalysis and the photographic process. Review in A37, 141.

Brice, J. C.: ThE GROWTH OF CRYSTAIS FROM LIQUIDS. (N. Holland, 1973). Review in J7, 637.

Chadwick, G. A. \& Smith, D. A.: Grain boundary strucTURE AND PROPERTIES. (Academic Press, 1976).

Chernov, A. A. (Ed.): Growth of Crystals, Vol. 11. (Plenum, 1979). This is the latest volume of a continuing series, edited previously by Sheftal (see below); each volume is a collection of specialised papers, translated from Russian.

Cullen, G. W. et al. (Eds.): VAPOUR GROWTH AND IPITAXY. (N. Holland, 1975). Conf. proc. Review in J10, 212.

Elwell, D. \& Scheel, H. J.: Crystal growth from high tem Perature solutions. (Academic Press, 1975). Not as limited as its title suggests, this is a good all-round book on crystal growth from solution. Review in A32, 1035.

Faktor, M. M. \& Garrett, I.: GROWTH OF CRYSTALS FROM THF VAPOLR. (Chapman \& Hall, 1974).

Freyhardt, H. C. (Ed.): CRYSTALS: GROWTH, PROPERTIFS AND applications, Vols. 2, 3 and 4. (Springer, 1980, 1980 and 1981). Freyhardt is the managing editor of this series, which now runs to a 6 th Vol. For Vol. 1, see Rooijmanns; for Vol. 5, see Grabmaier. Reviews of Vols. 2, 3 and 4 in A36, 1093; J14, 354; and A38, 397.

Goodman, C. H. L. (Ed.): CRYSTAL GROWTH: THEORY AND THCHNiques, Vol. 1 (1974) and Vol. 2 (1978) (Plenum). Review of Vol. 2 in J13, 106. Available also in Russian translation (MIR, 1977).

Grabmaier, J. (Ed.): SiliCON (Vol. 5 of the series CRystals: GROWTH, PROPERTIES AND APPLICATIONS). (Springer, 1981). The managing editor of this series is Freyhardt; see above, for earlier Vols.

Guzik, Z. \& Obłakowski, J.: Synthetic monocrystals: METHODS OF GROWING. (in Polish) (Slask, 1973).

Hartman, P. (Ed.): CRystal growth: aN InTRODUC TION. (N. Holland, 1973).

Hawkins, D. T.: ChEMICAL VAPOUR DEPOSITION, 1960-1980: a bibliography. (Plenum, 1981).

Heimann, R. B.: Auflösung voN Kristallin. (Springer, 1975). Review, in English, in A33, 253.

Henisch, H. K.: Crystal growth in Gels. (Penn State Univ. Press, 1970). Review in J4, 270.

Ikornikova, N. J.: HYDROTHER MAL SYNTHESIS OF CRYSTALS IN CHLORIDE SYSTEMS. (in Russian) (Nauka, 1975).

Kaldis, E. \& Scheel, H. J. (Eds.): Crystal GRowth aND MATERIALS. (N. Holland, 1977). Review papers from the first European conference on crystal growth, 1976. Review in J11, 673.

Kaldis, E. \& Schieber, M. (Eds.): Crystal Growth AND EPITAXY FROM THE VAPOUR PHASE. (N. Holland, 1971). Conf. proc.
Keesee, A. M. et al. (Compilers): CRYSTAL GROWTH BIBLIOGRAPHY. (Plenum, 1979). Review in J13, 402. There is now a SUPPLEMENT available (Plenum, 1981).

Keller, W. \& Mühlbauer, A.: FloATING-ZONE SILICON. (Dekker, 1981). This is the second Vol. of the series PREPARATION AND PROPERTIES OF SOLID STATE MATERIALS; fOr Other Vols. see Wilcox, below.

Kolkert, W. J.: GROWTH OF HOMOCiENGOUS ORGANIC MIXED CRYSTALS BY REPEATED-PASS ZONE-LEVELLING. (Drukkerij Elinkwijk BV, Utrecht, 1974).

Kozlova, O. G.: GROWTH AND MOR PHOLOGY OF CRYSTALS. (in Russian) (Izd-vo Mosk. Univ-ta, 1980).

Kubiak, R. (Ed.): Problems of Crystal growth. Papers of the Committee of Crystallography, Polish Academy of Science. (in Polish) (PWN, Warsaw, 1978). See also Olejnik, under 2. Crystal Physics.

Laudise, R. A.: ThE growth OF SINGLE CRYSTALs. (Prentice Hall, 1970). Review in J5, 53. This is available in Russian translation (MIR, 1974).

Lefever, R. A. (Ed.): AsPECTS OF CRYSTAL GROWTH. (Dekker, 1971). This is the first Vol. of the series PrEparation AND PROPERTIES OF SOLID STATE MATERIALS; for other Vols., see Wilcox, below.

Lemmlein, G. G.: MORPhOLOGY AND GENESIS OH CRYSTALS. (in Russian) (Nauka, 1973).

Lobacher, A. N.: Hydrothermal SYNTHISIS OF CRYSTALS. (Plenum, 1971). Translation from Russian.

Lobacher, A. N. (Ed.): Crystallisation processes Undili hydROTHERMAL CONDITIONS. (Plenum, 1973). Translation from Russian.

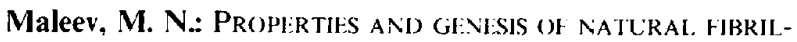
LAR CRYSTALS AND THEIR AGGREGATES. (in Russian) (Nauka, 1971).

Matthews, I. W. Epitaxial growth, Parts A and B. (Academic Press, 1975).

Mullin, J. W.: CRYSTallisation, 2nd ed. (Butterworth, 1972).

Mullin, J. W. (Ed.): INDUSTRIAL CRYSTALLISATION. (Plenum, 1976). Review in J10, 508.

Nitsche, R.: Information Über Kristallzuchtung. Deutsche Gesellschaft f. Kristallwachstum, 1976).

Ohara, M. \& Reid, R. C.: Modelling CRystal growth RATES FROM SOLUTION. (Prentice Hall, 1973).

Pamplin, B. R. (Ed.): Crystal growth. (Pergamon, 1975). Review in A33, 686. (There is now a 2nd ed., 1980).

Pamplin, B. R. (Ed.): Progress in CRYSTAL Growth aND AsSessmeni. (Pergamon). A new review journal; the first issue was in 1977.

Pamplin, B. R. \& Elwell, D. (Eds.): InORGanic biological (RYSTAL GROWTH. (Pergamon, 1981).

Parker, R. L. el al. (Eds.): CRYSTAL GROWTH, 1977. (N. Holland, 1977). Conf. proc. Review in J11, 720.

Platenko, J. A. et al:: MiNeralogical CRYSTAL CHEMISTRY OF TITANIUM. (in Russian) (Nauka, 1976).

Rooijmans, C. J. M.: CRYSTALS HOR MAGNeTIC A PPLIC:ATIONS. (Springer, 1978). This is the first of a new series, edited by Rooijmans, on crystal growth (see Freyhardt, above) Review of this Vol. in J12,642.

Rosenberger, F.: FLNDAmintals of CRYSTAL growth, 1 (Springer, 1979). Review in J13, 401.

Rousseau, R. W.: ANALYSIS AND DESIGN OF CRYSTALIISATION PROCESSES. (American Inst. of Chem. Engineers, NY, 1976). 
Salli, I. V.: CRYSTALliSATION AT VERY HIGH COOLING RATES. (in Russian). (Naukova Dumka, 1971).

Savitskii, E. M.: MONOCRYSTALS OF METALS: GROWTH AND PROPERTIES. (in Russian). (Nauka, 1976).

Savitskii, E. M. \& Burkhanov, G. S.: Monocrystals of HIGH-MELTING AND RARE EARTH METALS AND ALLOYS. (in Russian) (Nauka, 1972).

Shafranovskii, I. I.: LECTURES ON CRYSTAL MORPHOLOGY. (Balkema, Rotterdam, 1973). Translation of the Russian version of 1968. Review in A32, 1038.

Shapiro, C. M.: Crystal formation: bibliography, Vols. 1 and 2. (in Russian) (Nauka, 1970).

Sheftal, N. N. (Ed.): Growth OF CRYSTALs, Vol. 9 (1975) and Vol. 10 (1976) (Plenum). See comment under Chernov, above. Review of these Vols. in A32, 1036 and A34, 1045.

Tarján, I. \& Mátrai, M.: LABOR.ATORY MANUAL ON CRYSTAL GROWTH. (Akadémiai Kiadó Budapest and UNESCO, 1972).

Ueda, R. \& Mullin, J. B. (Eds.): Crystal Growth AND Characterisation. (N. Holland, 1975). Conf. proc. Review in A33, 254.

Wilcox, W. R. (Ed.): CHEMICAL VAPOR TRANSPORT, SECONDARY NUCLEATION AND MASS TRANSFER IN CRYSTAL GROWTH. (Dekker, 1976).

Wilcox, W. R. (Ed.): Growth MEChanisms and SILICON NITRIDE. (Dekker, 1982). This is the most recent volume of the series, published by Dekker, entitled PrEParation AND PROPERTIES OF SOLID STATE MATERIALS; for the earlier Vols., see Keller, Lefever and Wilcox.

Wilcox, W. R. (Ed.): Lead tin TElluride, SILVER halides, AND CZOChralski GROWTH. (Dekker, 1981).

Wilcox, W. R. (Ed.): MORPHOLOGICAL STABILITY, CONVECTION, GRAPHITE, AND INTEGRATED OPTICS. (Dekker, 1979).

Wilcox, W. R. \& Lefever, R. A. (Eds.): III-V alloys, CONVECTIVE INSTABILITIES AND NUCLEATION. (Dekker. 1977).

Wilke, K.-T. \& Bohm, J.: KristallzüchtUng. (VEB Verlag, 1973). Review, in English, in J7, 450.

Woodruff, D. P.: THE SOLID-LIQUID INTERFACE. (CUP, 1973, and now a paperback, 1980).

\section{Crystal Physics/Physics of Condensed Matter}

Achenbach, J. D.: Wave propagation in elastic solids. (Elsevier, 1973). Review in J7, 408.

Agranovich, V. M. \& Ginzburg, V. L.: CRYSTAL OPTICS WITH REGARD TO SPACE DISPERSION AND EXCITON THEORY. (in Russian) (Nauka, 1979).

André, J.-M. \& Ladik, J. (Eds.): Electronic Structure OF POLYMERS AND MOLECULAR CRYSTALS. (Plenum, 1975). Review in A33, 253.

Animalu, A. O. E.: Intermediate Quantum theory of CRYSTAlline SOLIDS. (Prentice Hall, 1977). Review in A34, 478.

Ashcroft, N. W. \& Mermin, N. D.: Solid state physics. (Holt Reinehart, 1976).

Auluck, F. C. (Ed.): SOlid STATE PHYSiCs, Vols. 1 and 2. (Thomson, New Delhi, 1971). Conf. proc.

Bartolo, B. D. (Ed.): OptiCAL PROPERTIES OF IONS IN SOLIDS. (Plenum, 1975). NATO inst. lectures. Review in A33, 685.
Bartolo, B. D. et al. (Eds.): LuMINESCENCE OF INORGANIC solids. (Plenum, 1978). Conf. proc.

Bassani, G. F. \& Pastori, P. G.: Electronic states and OPTICAL TRANSITIONS IN SOLIDS. (OUP, 1975).

Becker, P.: Electron aNd MaGNetisation DENSITIES IN MOLECULES AND CRYSTALS. (Plenum, 1980). NATO inst. lectures. Review in A36, 1092.

Blakemore, J. S.: Solid STATE PHYsics. (Florida State Univ., 1974).

Bonse, U.: INTERFEROMETRIE MIT RöNTGEN- UND NEUTRONENSTRAHLEN. (Westdeutscher Verlag, 1977).

Brodin, M. S. (Ed.): EXcitons IN MOLECULAR CRYSTALS. (in Russian) (Naukova Dumka, 1973).

Brüesch, P. (Ed.): PHONONS: THFORY AND EXPERIMENTS, I: LATTICE DYNAMICS AND MODELS OF INTERATOMIC FORCES. (Springer, 1982).

Bube, R. H.: ElECTRONIC PROPERTIES OF CRYSTALLINE SOLIDS: an introduction to fUndamentals. (Academic Press, 1974).

Bugakov, V. Z.: Diffusion IN METALS AND alloys. (Israel Program for Scientific Translation, 1971).

Busch, G. \& Schade, H.: LeCTURES ON SOLID STATE PHYSICS. (Pergamon, 1976). This is the English edition of the German original VoRLESUNGEN ÜBER FESTKÖRPERPHYSIK (Birkhäuser, Basel, 1973). An elementary guide. Review in A33, 1044.

Califano, S. (Ed.): LatTice dynamics AND INTERMOleCUlaR FORCES. (Academic Press, 1975).

Califano, S. et al: LATtice DYNamiCs OF MOLECUlAR CRYSTALS. (Springer, 1981).

Callaway, J.: Quantum theory of The Solid STate, Parts A and B. (Academic Press, 1974). Review in A34, 349.

Chadwick, G. A. (Ed.): Grain boundary STRuCture and PROPERTIES. (Academic Press, 1976).

Chakraverty, A. S.: INTRODUCTION TO THE MAGNETIC PROPERTIES OF SOLIDS. (Wiley, 1980).

Cochran, W.: THE DYNAMiCS OF ATOMS IN CRYSTALS. (Arnold, 1973). Highly recommended by the reviewer, in A30, 604.

Coleman, R. V.: SOlid STATE Physics. (Academic Press, 1973).

Coles, B. R.: The Electronic Structures of solids. (Arnold, 1975).

Cowley, J. M.: Modulated structures. (American Inst. of Physics, 1979).

Cracknell, A. P.: Magnetism in CRystalline materials. (Pergamon, 1975).

Crangle, J.: The magnetic properties of solids. (Arnold, 1977).

Crow, J. E. et al. (Eds.): CRystalline eleCtRic field AND STRUCTURAL EFFECTS IN $f$-ELECTRON SYSTEMS. (Plenum, 1980). Review in A37, 142.

Cyvin, S. J.: Molecular Structures and vibrations. (Elsevier, 1972).

Dearnaley, G.: ION IMPlantation. (N. Holland, 1973).

Decius, J. C. \& Hexter, R. M.: Molecular vibrations in CRYSTALS. (McGraw-Hill, 1977). Review in A35, 701.

Devreese, J. T. et al. (Eds.): RECENT DEVELOPMENTS IN CONDENSED MATTER PHYSICS, Vols. 1-4. (Plenum). This records the proceedings of the European Physical Society conference of April 1980 at Antwerp. Vol. 1 (1981): invited papers; Vol. 2 (1981): metals, disordered systems, surfaces and interfaces; Vols. 3 and 4 (still unpublished): impurities, 
excitons, polarons and polaritons; and low-dimensional systems, phase changes and experimental techniques, respectively.

Domb, C. \& Green, M. S. (Eds.): Phase transitions and CRitical PHenomena. (Academic Press, 1972).

Donovan, B. \& Angress, J. F.: Lattice vibrations. (Chapman \& Hall, 1971).

Dorner, B.: COHERENT INELASTIC NEUTRON SCATTERING IN LATTICE DYNAMICS. (Springer, 1982).

Dugdale, J. S.: THE EleCtriCAl PROPERTIES OF METALS AND ALLOYS. (Arnold, 1977).

Elliott, R. J. \& Gibson, A. F.: An InTRODUCtion to SOLID STATE PHYSICS AND ITS APPLICATIONS. (Macmillan, 1974).

Epifanov, G.: Solid STATE PHysics. (MIR, 1979).

Evans, C. C.: Whiskers. (Mills \& Boon, 1972).

Fletcher, G. C.: THE ELECTRON BAND THFORY OF SOLIDS. (N Holland, 1971).

Freeman, A. J. \& Schmid, H. (Eds.): Magneto-electronic INTERACTION PHENOMENA IN CRYSTALS. (Gordon \& Breach, 1975). Review in A32, 176.

Fumi, F. G. (Ed.): Physics of Semiconductors. (N. Holland, 1976). Conf. proc

Geballe, T. H. \& White, R. M.: LONG RANGe ORdeR IN SOLIDS. (Academic Press, 1979).

Geguzin, J. E.: GrundzüGE der Diffusion in Kristallen. (VEB Deutscher Verlag f. Grundstoffindustrie, 1977).

Geguzin, J. E. \& Krivoglaz, M. A.: Migration OF MACrOSCOPIC INCLUSIONS IN SOLIDS. (Consultants Bureau, 1973).

Ghatak, A. K. \& Kothari, L. S.: AN INTRODUCTION TO LATTICE DYNAMICS. (Addison Wesley, 1972).

Goodman, C. H. L. (Ed.): CRYSTAL GROWTH: THEORY AND TECHNIQUES, Vol. 1 (1974) and Vol. 2 (1978). (Plenum). This is also availabie in Russian translation (MIR, 1977). Review of Vol. 2 in J13, 106.

Hall, H. E.: Solid STATE PHYSiCs. (Wiley, 1974).

Hardy, J. R. \& Karo, A. M.: Lattice Dynamics and statics OF ALKALI HALIDE CRYSTALS. (Plenum, 1979). Review in A37, 270 .

Harrison, W. A.: Electronic STRUCTURE AND PROPERTIES OF SOLIDS. (Freeman, 1980).

Hart-Davis, A.: Solids: AN introduction. (McGraw-Hill, 1975).

Haug, A.: TheORETISCHE FESTKöRPER PHYSIK, Band II. (Franz Deuticke, 1970). Now also in English: THEORïTICAL SOLID STATE PHYSICS, Vols. 1 and 2. (Pergamon, 1972).

Heimann, R. B.: Auflösung von Kristallen. (Springer, 1975). Review, in English, in A33, 253. Available also in Russian translation (Nauka, 1973).

Hellwege, K. H.: EINFÜHRUNG IN DIE FESTKöR PER PHYSIK, 2. Aufl. (Springer, 1981).

Herman, F. el al. (Eds.): Computational sOLID STATE PHysics. (Plenum, 1972). Conf. proc.

Herrmann, R. \& Preppernau, U.: Elektronen im Kristall. (Springer, 1979). Review, in English, in A36, 1091.

Hirsch, P. B. (Ed.): The physics of METals, Vol. 2: Defects. (CUP, 1975).

Hobbs, P. B.: ICE Physics. (OUP, 1975). See also Tryde, below.

Hodgson, J. N.: OPTICAL ABSORPTION AND DISPERSION IN Solids. (Chapman \& Hall, 1970).

Horton, G. K. \& Maradudin, A. A. (Eds.): DYNAmICAL PROPERTIES OF SOLIDS. Vols, 1, 2, 3 and 4. (N. Holland,
1974, 1975, 1980 and 1980 respectively). Review of Vol. 2 in A32, 1035. A strongly theoretical emphasis.

Ivanovov, L. I.: MELTING, CRYSTALLISATION AND PHASE FORMATION IN WEIGHTLESSNESS: EXPERIMENT IN THE FRAME OF THE PROJECT 'Soyuz-Apollo'. (in Russian) (Nauka, 1979).

Ivernova, V. l. \& Katsnel'son, A. A.: SHORT-RANGE ORDER IN SOLID SOLUTIONS. (in Russian) (N!auka, 1977).

Jones, H.: THE THEORY OF BRILLOUIN ZONES AND ELECTRONIC STATES, 2nd ed. (N. Holland, 1975). Gives the basic mathematics of the Schrödinger equation for the electron in particular crystallographic space-group symmetries. Review in A32, 926.

Jones, W. \& March, N. H.: Theoretical solid STATE PHYSICS, Vols. 1 and 2. (Wiley, 1973).

Juretschke, H. J. \& Villars, F. M. H.: CRYSTAL PHYSICS. (Addison Wesley, 1975). Review in A32, 924.

Kachanov, L. M.: FUNDAMENTALS OF THE THEORY GF PLASTlCITY. (MIR, 1974)

Keller, H. J. (Ed.): Chemistry and PHysics OF ONE-DIMENSIONAL METALS. (Flenum, 1977). (See also 14. Materials of Low Dimensionality.) Review in B34, 2068.

Kelly, B. T.: Physics OF GRAPHITE. (Applied Science, 1981).

Kittel, C.: InTroduction to SOLID STATE PHySiCs, 5th ed. (Wiley, 1976). Also available in Polish translation (PWN, Warsaw, 1976).

Klein, M. L. \& Venables, J. A. (Eds.): RaRE GAS SOLIDS, Vols 1 and 2. (Academic Press, 1976 and 1977). Review in A34, 639.

Konakov, P. K.: HEAT AND MASS-EXCHANGE DURING GROWTH OF MONOCRYSTALS. (in Russian) (Metallurgija, 1971).

Krishnan, R. S. et al:: THERMAL EXPANSION OF CRYSTALS. (Pergamon, 1979). Warmly recommended by the reviewer: A37, 142.

Kubiak, R. (Ed.): PROBLEMS OF CR YSTAL PHYSICS. Papers of the Committee of Crystailography, Polish Academy of Science (in Polish) (PWN, Warsaw, 1979). See also Olejnik, below.

Lekhnitsky, S.: ELASTIC THEORY OF ANISOTROPIC SOLIDS. (MIR, 1980).

Lenz, D. \& Lucke, K. (Eds.): INTERNAL FRICTION AND ULTRASONIC ATTENUATION IN CRYSTALLINE SOLIDS. (Springer, 1975). Conf. proc.

Lovesey, S. W. et. al. (Eds.): DyNAMICS of SOLIDS AND LIQUIDS BY NEUTRON SCATTERING. (Springer, 1977).

Lovett, D. R.: SEMIMETALS AND NARROW BANDGAP SEMICONDUCTORs. (Academic Press, 1977). Review in J12, 262.

Ludwig, W.: FESTKÖRPERPHYSIK, I und II. (Akademie-Verlag, 1970).

Madelung, O.: INTRODUCTION to SOLID STATE THEORY. (Springer, 1978). Review in A35, 1087.

Manning, J. R.: KINETICS OF ATOM DIFFUSION IN CRYSTALS. (Russian translation from English) (MIR, 1971).

March, N. H. \& Parrinello, M.: Collective effects iN SOLIDS AND LIQUIDS. (Hilger, 1982).

Maris, H. J. (Ed.): Phonon scattering in CONDENSED MATTER. (Plenum, 1980). Conf. proc. Review in A37, 272.

Marshall, W. \& Lovesey, S. W.: THEORY OF THERMAL NELTRON SCATTERING. (Clarendon, 1971).

Mie!ankholin, N. M.: Methods OF INVESTIGation OF THE OPTICAL PROPERTIES OF CRYSTALS. (in Russian) (Moskva, 1970).

Metzger, R. M. (Ed.): Crystal cohesion and conformational energies. (Springer, 1981). 
Mitsui, T. et al.: AN INTRODUCTION to THE PHYSICS OF FERROELECTRICS. (Gordon \& Breach, 1976). On this subject, see also Conolly (and a number of other authors), listed in 18. Miscellaneous.

Mott, N. \& Davis, E. A.: Electronic Processes in NONCRYSTALLINE MATERIALS. (OUP, 1979).

Muir, L. E.: Interfacial PHENOMENA IN METALS AND ALLOYS. (Addison Wesley, 1975).

Musgraye, M. J. P.: Crystal acoustics. (Holden Day, 1970). Review in A27, 699.

Narasimhamurty, T. S.: Photoelastic and electrooptic PROPERTIES OF CRYSTALS. (Plenum, 1981). Review in A38, 399.

Nechvolod, N. K.: CReEPING OF CRystalline solids at LOW TEMPERATURES. (in Russian) (Kiev, 1980).

Nemoshkalenko, V. V. \& Aleshin, V. G.: Electron SPECTROSCOPY OF CRYSTALS. (Plenum, 1979). Translated from Russian.

Nowick, A. S. \& Berry, B. S.: Anelastic relaxation in CRYSTAlline Solids. (Academic Press, 1972).

Nowick, A. S. \& Burton, J. J.: Diffusion in SOlids. (Academic Press, 1975).

Ogawa, T.: Physics and engineering OF CRystals. (in Japanese) (Shokabo, 1976).

Olejnik, S. (Ed.): Thermal Properties of CRYSTals. Papers of the Committee of Crystallography, Polish Academy of Science. This is the first of a series of pamphlets dealing with the present state of a given area of crystallography (in Polish) (PWN, 1975).

Omar, M. A.: Elementary solid state Physics. (Addison Wesley, 1975).

Pietronero, L. \& Tosatti, E. (Eds.): Physics of intercalaTION COMPOUNDS. (Springer, 1981).

Poirier, J. P.: Plasticité a haute température des solides CRYSTALlins. (Eyrolles, Paris, 1976).

Poulet, H. \& Mathieu, J. P.: Vibration spectra AND SYMMETRY OF CRYSTALS. (Gordon \& Breach, 1976). Translated from French.

Press, W.: Single particle rotations in molecular crysTALS. (Springer, 1981).

Rabii, S.: Physics of IV-VI COMPOUNDS AND Alloys. (Gordon \& Breach, 1975). Review in A32, 176.

Rao, C. N. R. \& Rao, K. J.: Phase transitions in solids. (McGraw-Hill, 1978). Review in A36, 332.

Rashba, E. I. \& Sturge, M. D. (Eds.): Excitons. (N. Holland, 1982).

Riste, T. (Ed.) Fluctuations, instabilities and Phase TRANSITIONS. (Plenum, 1975). Conf. proc.

Riste, T. (Ed.): LatTices, STRUCTURAL Transitions AND MELTING. (Noordhoff, 1974).

Riste, T. (Ed.): ORDERING IN STRONGLY FLUCTUATING CONDENSED MATTER SYSTEMS. (Plenum, 1980). Review in A37, 445 .

Rosenberg, H. M.: The SOlid STATE, 2nd ed. (Clarendon, 1978). Review of the 1st ed. in A33, 347.

Schlenker, M. et al. (Eds.): IMAGING PROCESSES AND COHFRENCE IN PHYSICS. (Springer, 1980).

Schneider, H. G.: Advances in EPITAXY AND ENDOTAXY. (Akadémiai Kiadó, Budapest, 1976).

Schneider, H. G.: Strukturen kristalliner PhasengrenZEN. (VEB Verlag, 1976).

Schulze, G. E. R. \& Paufler, P.: Die Plastische Verfor-
MUNG 'SPRODER' INTERMETALLISCHER VERBINDUNGEN UND IHRE ELEMENTARPROZESSE. (Akademie-Verlag, 1972).

Seitz, F. et al. (Eds.): SOlID STATF PHYSICS: adVANCES IN Research and applications. (Academic Press). This is essentially a review journal; successive volumes and supplements are annual, each with three or four highly specialised reviews; crystallographic topics, though infrequent, have included the martensite transformation (Vol. 33, 1978), liquid crystals (Suppl. 14, 1978), and long-range order in solids (Suppl. 15, 1979).

Seraphin, B. O. (Ed.): OptiCal Properties of SOlids. (N. Holland, 1976). A collection of review articles.

Sherwood, P. M. A.: Vibrational SPECTROSCOPY OF SOLIDS. (CUP, 1972).

Silinsh, E. A.: Organic MOLECUlAR CRYSTALS: THEIR ELECTRONIC STATES. (Springer, 1980). Translation from Russian.

Simmons, G. \& Wang, H.: Single crystal elastic conSTANTS AND CALCULATED AGGREGATE PROPERTIES, 2 nd ed. (MIT Press, 1971).

Sirota, N. N. (Ed.): RADIATION PHYSICS OF NONMETALLIC CRYSTALS. (in Russian) (Nauka i Technika, 1971).

Sirotin, Yu. I. \& Shaskol'skaya, M. P.: A SUR VEY OF CRYSTAL PHYSICS. (in Russian). (Nauka, 1975). Review, in Russian, in $\mathrm{A35}, 252$.

Sonin, A. S. \& Vasilevskaia, A. S.: ElectroOPTICAL CRYSTALS. (in Russian) (Atomizdat, 1971).

Sorin, L. A. \& Vlasova, M. V.: Electron SPIN RESONANCE OF PARAMAGNETIC CRYSTALS. (Plenum, 1973). Translated from Russian.

Sprackling, M. T.: The PlaStiC DEFORMATION OF SIMPLE IONIC CRYstals. (Academic Press, 1976). Review in A34, 351.

Stanley, H. E.: INTRODUCTION TO PHASE TRANSITIONS AND CRITICAL. PHENOMENA. (OUP, 1971).

Stark, J. P.: Solid STATE diffusion. (Wiley, 1976).

Steeds, J. W.: Introduction to anisotropic ELASTICITY THEORY OF DISLOCATIONS. (Clarendon, 1973).

Stiddard, M. H. B.: The elfmentary language of SOlid STATE PHYSICS. (Academic Press, 1975).

Stolz, H.: EinfüHRUNG IN dIE VIELELEKTRONEN THEORIE DER Krist ALlE. (Akademie-Verlag, 1974).

Strechnikov, V. N. (Ed.): Diffusion PROCESSES IN METALS. (US Dept of Commerce, 1970).

Swalin, R. A.: Thermodynamics of solids. (Wiley, 1972).

Tanner, B. K.: X-RAY TOPOGRAPHY. (Pergamon, 1976). An elementary treatment for the non-specialist. Review in A33, 861.

Tichý, J. \& Gautschi, G. H.: Pitzoelek trische MesstechniK, Physikalishe Grunlagen, Kraft-, DruckUND BESCHLEUNIGUNGSAUfNEHMER, VERSTARKER. (Springer, 1980).

Trefilov, V. I. (Ed.): RADIATION EFFECTS IN SOLIDS. (in Russian) (Naukova Dumka, 1977).

Tryde, P. (Ed.): Physics and Mechanics of ICE. (Springer, 1980). Symp. proc. Review in A37, 143. See also Hobbs, above.

Turrell, G.: INFraRed and Raman SPECTRA OF CRYSTALS. (Academic Press, 1972).

Venkatamaran, G. et al:: DYNAMICS OF PERFECT CRYSTALS (MIT Press, 1975).

Verma, A. R. \& Srivastava, O. N.: CRYSTAllogRaPHy fOR SOLID STATE PHYSICS. (Wiley-Eastern, New Delhi, 1973). 
Vladimirov, V. I.: Physical THEORY OF PLASTICITY AND STRENGTH, Vol. 1: DefECTS OF CRYSTALline latTICES. (in Russian) (Leningrad, 1973).

Wallace, D. C.: Thermodynamics OF CRYSTALS. (Wiley, 1972).

Warlimont, J. H. (Ed.): ORDER-DISORDER TRANSFORMATIONS IN ALLOYS. (Springer, 1974). Symp. proc.

Weissmantel, C. et al:: GRUNDLAGEN DER FESTKÖRPERPHYSIK. (VEB Verlag, 1978).

Wieting, T. J. \& Schülter, M.: EleCTRONS AND PHONONS IN LAYERED CRYSTAL STRUCTURES. (Reidel, 1981). Reidel is publishing a set of six or seven books on layered structures; see also the sections on Materials $(11$ to 14$)$ and Solid State Chemistry (25).

Wilkes, P.: Solid state theory in Metallurgy. (CUP, 1973). Review in J7, 94. Also available in Polish translation (PWN, Warsaw, 1974).

Williams, F.: LUMINESCENCE OF CRYSTALS, MOLECULES AND SOLUTIONS. (Plenum, 1973).

Willis, B. T. M. \& Pryor, A. W.: Thermal vibrations in CRYSTALLOGRAPHY. (CUP, 1975).

Wood, E. A.: CRystals AND LIGHT: an INTRODUCTION to OPTICAL CRYSTALLOGRAPHY. (Dover, 1977). This is revised from the 1964 edition; a delightful little book.

Wooster, W. A.: TENSORS AND GROUP THEORY FOR THE PHYSICAL PROPERTIES OF CRYSTALS. (OUP, 1973).

Wooster, W. A. \& Bretton, A.: Experimental CRYSTAL PHysics, 2nd ed. (OUP, 1970). A unique book of practical instructions. Review in J4, 401.

Wooten, F.: OPTICAL PROPERTIES OF _uLIDS. (Academic Press, 1972).

Zheludev, I. S.: Physics of CRYSTAlline Diblectrics. (Plenum, 1971).

\section{Defects/Faults/Impurities}

Balian, R. et al. (Eds.): ILL-CONDENSED MATTER. (N. Holland, 1979). Substance of a summer school. Review in A36, 1094.

Balian, R. et al. (Eds.): Physics of DEFECTs. (N. Holland, 1982). Proc. of the summer school of 1980.

Bollmann, W.: CRYSTAL DEFECTS AND CRYSTAL INTERFACES. (Springer, 1970). Review in A27, 302.

Born, E. \& Paul, G.: Röntgenbelgung am Realkristall. (Verlag Karl Thiemig, 1979). Review in A37, 140.

Burton, B.: Diffusional CREEP OF POLyCRystalline material.s. (Trans. Tech. Publ., 1977).

Dearnaley, G.: ION IMPLANTATION. (N. Holland, 1973).

De Batist, R.: Internal Friction of Structural DFFects in CRYSTALline SOlids. (N. Holland, 1972).

Eyring, L. \& O'Keeffe, M. (Eds.): Chemistry of EXTENDED DEFECTS IN NON-METALLIC SOLIDS. (N. Holland, 1970). Review in B27, 1839.

Farge, Y. \& Fontana, M. P.: El.ectronic and vibrational PROPERTIES OF POINT DEFECTS IN IONIC CRYSTALS. (N. Holland, 1979). Review in A37, 138.

Figielski, T. (Ed.): POINT DEFECTS AND THEIR INTERACTION WITH OTHER LATTICE IMPERFECIIONS. (PWN, Warsaw, 1974). Summer school proc.

Flynn, C. P.: Point defects and diffusion. (OUP, 1972).

Fujita, E.: LATTICE DefeCTS. (in Japanese). (Asakura Shoten, 1980).
Geguzin, J. E. \& Krivoglaz, M. A.: MUvement of MACROSCOPIC INCLUSIONS IN SOLIDS. (in Russian) (Atomizdat, 1972).

Gehlen, P. C. (Ed.): Interatomic potentials and simulaTION OF LATTICE DEFECTS. (Plenum, 1972). Conf. proc.

Gittus, J.: IrRADIaTION EFFECTS IN CRYSTALline SOlIDS. (Applied Science/Wiley, 1978).

Hayes, W. (Ed.): CRYSTALS WITH THE FluORITE STRUCTURE: ELECTRONIC, VIBRATIONAL AND DEFECT PROPERTIES. (OUP, 1975).

Henderson, B.: Defects in CRystalline solids. (Arnold, 1972).

Henderson, B. (Ed.): DefeCtS AND THEIR STRUCTURE IN NONMETALliC SOLIDS. (Plenum, 1976).

Henderson, B. \& Wertz, J. E.: Defects in the alkaline EARTH OXIDES WITH APPLICATIONS TO RADIATION DAMAGE AND CATALYSIS. (Taylor \& Francis, 1977).

Hirth, J. P. \& Lothe, J.: Dislocation THEORY. (Atomizdat, 1972). Russian translation from English.

Hughes, A. E. \& Pooley, D.: Real solids and Radiation. (Wykeham, 1975). Review in J9, 371.

Hull, D.: Introduction to Dislocations, 2nd ed. (Pergamon, 1975).

International Atomic Energy Agency: THEORY OF IMPERFECT CRYSTALLINE SOLIDS. (IAEA, 1971).

Kabaieva, V. M. (Ed.): DisLOCATIONS IN CRYSTALS: BIBLIOGRAPHY OF NATIONAL AND FOREIGN LITERATURE, Vol. 4. (in Russian) (Nauka, 1977). For Vol. 3, see Slesareva, below.

Kelly, A. \& Groves, G. W.: CRYSTAllography AND CRYSTAL DEFECTS. (Longman, 1970). Review in J9, 262. This is also available as KRISTALlografiYa in Russian translation (MIR, 1974) and in Polish translation (PWN, 1980).

Kofstad, P.: NONSTOICHIOMETRY, DIFFUSION AND ELECTRICAL CONDUCTIVITY IN BINARY METAL OXIDES. (Wiley, 1972).

Kosevich, V. M.: Dislocation's IN THE THEORY OF ELASTICITY. (in Russian) (Naukova Dumka, 1978).

Kovács, I. \& Zsoldos, L.: DISLOCATIONS AND PLASTIC DEFORMATION. (Pergamon, 1974). Review in J8, 78.

Kröger, F. A.: THE CHEMISTRY OF IMPERFECT CRYSTALS, Vols. 1,2 and 3. (N. Holland, 1974). Massive and very detailed. Review in J8, 497.

Lawn, B. R.: Fracture OF BRITTLE SOLIDS. (CUP, 1975).

Lehmann, C.: INTERACTION OF RADIATION WITH SOLIDS AND ELEMENTARY DEFECT PRODUCTION. (N. Holland, 1977).

Loretto, M. H. \& Smallman, R. E.: DefECT ANALYSIS IN ELECTRON MICROSCOPY. (Chapman \& Hall, 1975).

Mitra, S.: Physics OF STRLCTURALly DISORdered SOlids. (Plenum, 1976).

Morgan, A. R.: Collisions, CoAlescence and CRystals. (Methuen, 1972).

Mrowec, S.: Defects avd diffusion IN SOLIDs. (Elsevier/Polish Scientific Publ., 1980). Review in A37, 141.

Nabarro, F. R. N. (Ed.): Dislocations in CRYSTALS, Vols. 1, 2 and 3. (N. Holland, 1978, 1979 and 1980). A further three Vols. are in preparation. Reviews of Vols. 1 and 2 in A37, 143 and A36, 835 .

Newman, R. C.: Infra-Red STUdies of CRYSTAL DEFECTS. (Taylor \& Francis, 1973).

Ovsienko, D. E. (Ed.): Growth aNd Defects IN METAlliC CRYSTALS. (in Russian) (Irkutsk, 1977).

Parfianovich, I. A. \& Penzina, E. E.: Electron colour CENTRES IN IONIC CRYSTALS. (in Russian) (Irkutsk, 1977). 
Parsonage, N. G. \& Staveley, L. A. K.: DisORder IN CRYSTALS. (OUP, 1978). Review in A36, 332.

Poirier, J. P.: Plasticité à haute température des solides CRISTAllins. (Eyrolles, Paris, 1976).

Predvoditelov, A. A. \& Troickij, O. A.: Dislocations AND POINT DEFECTS IN HEXAGONAL METALS. (in Russian). (Atomizdat, 1973).

Rebane, K. K.: IMPURITY SPECTRA OF SOLIDS. (Plenum, 1970).

Seltzer, M. S.: DEFECTS AND TRANSPORT IN OXIDES. (Plenum, 1973).

Slesareva, N. V. (Ed.): Dislocations IN CRYSTALS: BibliogRAPHY OF NATIONAL AND FOREIGN LITERATURE, Vol. 3. (in Russian) (Nauka, 1974). See also Kabaieva, above.

Serensen, O. T.: NonstolChometriC OXIDES. (Academic Press, 1981).

Startsev, V. I. (Ed.): DYNamics OF Dislocations. (in Russian) (Naukova Dumka, 1975).

Stoneham, A. M.: THEORY OF DEFECTS IN SOLIUS. (OUP, 1975). Review in A32, 527.

Suzuki, H.: LATTICE DEFECTS. (in Japanese). (Kyoritsu Shuppan, 1978).

Svechnikov, V. N.: DEFECTS OF CRYSTAL STRUCTURE. (in Russian). (Naukova Dumka, 1971).

Tanner, B. K. \& Bowen, D. K. (Eds.): Characterisation of CRYSTAL GROWTH DEFECTS BY X-RAY METHODS. (Plenum, 1980). NATO inst. proc. Review in J15, 140.

Teodosin, C. Elastic models of CRYstal Defects. (Springer, 1982).

Townsend, P. D. \& Kell, J. C.: Colour CENTres AND IMPERFECTIONS IN INSULATORS AND SEMICONDUCTORS. (Crane, Russak, 1973).

Tuchkevich, V. M. \& Shvarts, K. K. (Eds.): DefFects IN INSULATING CRYSTALS. (Springer, 1982). Conf. proc.

Udowski, H.-E.: Fraktionierung der SPURENELEMENTE beI DER KRISTAllisation. (Springer, 1975). Review in J9, 371.

Vladimirov, V. I.: PHYSICAL THEORY OF PLASTICITY AND STRENGTH, Vol. 1: DEFECTS OF CRYSTALLINE LATTICES. (in Russian) (Leningrad, 1973).

Watts, R. K.: PoInT DEFECTS. (Wiley, 1977). Review in A34, 160.

Wertheim, G. K. el al.: THF ELECTRONIC STRUCTURF OF POINT DEFECTS AS DETERMINED BY MÖSSBAUER SPECTROSCOPY AND BY SPIN RESONANCE. (N. Holland, 1971).

\section{Diffraction Theory}

Authier, A.: X-RAY OPTICS. (Springer, 1977).

Azaroff, L. V. et al.: X-RAY DIFFraction. (McGraw-Hill, 1974). Review in A31, 878.

Bedyńska, T.: DYNAMIC THEORY OF X-RAY DIFFRACTION IN THE CASE OF STRONGLY ASYMMETRIC SCATTERING AND Dislocation CONTRAST, (in Polish) (Ossolineum, Warsaw, 1978).

Brümmer, O. \& Stephanik, H. (Eds.): DYNAMISCHE INTERFERENZTHEORIE. (Geest \& Portig, 1976). Review in A33, 1045.

Cowley, J. M.: Diffraction Physics. (N. Holland, 1975). Review in A32, 748. A 2nd (revised) ed. is now available (1981).

Dawson, B. (Ed. by Hoppe \& Mason): AdvanCES IN STRUCTURAL RESEARCH BY DIFFRACTION METHODS, Vol. 6. (Pergamon, 1975). This particular Vol. deals with the precision determination of charge density distribution in crystals.
Review in A33, 254. For the other Vols. of the series, see Hoppe \& Mason, below.

Hargittai, I. \& Orville-Thomas, W. J. (Eds.): DIFFRACTION STUDIES ON NON-CRYSTALLINE SUBSTANCES. (Elsevier/Akadémiai Kiadó Budapest, 1981). Based on lectures given at the recent summer school in Hungary.

Hirshfeld, F. L. (Ed.): EleCTRON DENSITY MAPPING IN MOLECULES AND CRYSTALS. (Weizmann Scientific Press of Israel, 1977). Review in A35, 254.

Hoppe, W. \& Mason, R. (Eds.): Advances in structural RESEARCH BY DIFFRACTION METHODS, Vols. 3-7. (Pergamon/Vieweg). These Vols. are of considerable interest to the crystallographer; each normally contains two or three review articles. Vol. 3 (1970) contains articles by Authier and by Kambe \& Molière on the dynamical theory of $X$ ray diffraction and of electron diffraction respectively. Vol. 7 (1979) is separately listed, under Hoppe \& Mascn, in 6. Electron Microscopy.

Hukins, D. W. L.: X-RAY DIFFRACTION BY DISORDERED AND ORDERED SYSTEMS. (Pergamon, 1981). A fairly simple presentation.

Kato, N.: Diffraction and SCATtering. (in Japanese). (Asakura Shoten, 1978).

Lipson, H. (Ed.): Optical transforms. (Academic Press, 1972). See also Harburn, listed in 26. Student-Oriented Texts.

Pinsker, Z. G.: DynamiC behaviour of X-Rays IN IDEAL CRYSTAL.S. (in Russian) (Nauka, 1974).

Pinsker, Z. G.: Dynamical SCATTERING of X-RAYS IN CRYSTALS. (Springer, 1978). Review in A35, 347.

Queisser, H.-J. ([d.): X-RAY OPTICS. (Springer, 1977). Revicw in A35, 344.

Ramaseshan, S. \& Abrahams, S. C. (Eds.): Anomalous SCATTERING. (Munksgaard, 1975). Review in A32, 1037.

Schultz, J. M.: DIFFRACTION FOR MATERIALS SCIENTISTS. (Prentice Hall, 1981). A comprehensive treatment.

\section{Electron Diffraction}

Andrews, K. W. et al.: INTERPRETATION OF ELECTRON DIFFRACTION PATTERNS. (2nd ed.: Plenum, 1970). Also available in Russian translation (MIR, 1971).

Authier, A. et al: Principles ANd Methods of CONTEMPORARY ELECTRONOGRAPHY. (Polish translation) (Ossolineum, Warsaw, 1972).

Cowley, J. M.: Diffraction Physics. (N. Holland, 1975). The theoretical basis of diffraction, ED in particular. Review in A32, 748. A 2nd (revised) ed. is now available (1981).

Dobson, P. J. et al. (Eds.): Electron DIFFraction, 1927-1977. (Inst. of Physics, London, 1978). Review in A35, 349.

Goodman, P. (Ed.): FifTy years of EleCtron DifFraCtion. (Reidel, 1981). This record of the discovery and development of ED (which should not be confused with the book by Dobson, entitled 'ElFCTRON DIFFraction, 1927-1977', which is not a history of the subject) was commissioned by the IUCr itself, and is remarkable for the number and eminence of its contributing authors.

Heymann, P.: ThÉorie dynamiQue de la microscopie eT DifFraction Ézectronique. (PUF, Paris, 1974).

Hoppe, W. \& Mason, R. (Eds.): Advances in structural RESEARCH BY DIFFRACTION METHODS, Vols. 3 and 5. 
(Vieweg, 1970 and 1974). These issues contain, respectively, an article by Kambe \& Molière on the dynamical theory of electron diffraction, and an article by Zeil on the determination of molecular structure by electron diffraction on gases.

Lipson, H. (Ed.): Optical TRANSForms. (Academic Press, 1972). Ch. 7 of this book deals with ED.

Pendry, J. B.: Low energy eleCtron difraction. (Academic Press, 1974). Review in J8, 403.

Rymer, T. B.: EleCtron difFraction. (Chapman \& Hall, 1970).

\section{Electron Microscopy}

Amelinckx, S. et al. (Eds.): Diffraction AND IMAGING TECHNIQUES IN MATERIALS SCIENCE, Vol. 1 (EM) and Vol. 2 (IMAGING AND DIFFraCtION). (N. Holland, 1978). This book is a revision of the 1970 edition.

Ash, E. A. (Ed.): Scanned Image microscopy, Vol. 2: IMAGING AND DIFFRACTION TECHNIQUES. (Academic Press, 1980).

Baracki, A.: Methods of CRYSTALlographic ANALYSIS IN ELECTRON MiCrosCopy. (in Polish). (Poznan, 1978).

Belk, J. A. (Ed.): ELECTRON MICROSCOPY AND MICROANAL YSIS OF CRYSTALLINE MATERIALS. (Applied Science, 1979).

Bethge, H. \& Heydenreich, J.: ELEKTRONENMIKROSKOPIE IN DER FESTKÖRPERPHYSIK. (Berlin-Ost, 1981).

Bowen, D. K. \& Hall, C. R.: Microscopy OF MATERIALS. (Macmillan, 1975).

Bowkett, K. M. \& Smith, P. A.: FiELd-ION microscopy. (N. Holland, 1970).

Brederoo, P. et al. (Eds.): Electron microscopy 1980, Vols. 1-4. (N. Holland, 1980). Congr. proc.

Edington, J. W.: Practical electron microscopy iN MATERIALS SCIENCE, Vols. 2 and 3 (1975) and 4 (1976) (Macmillan). Reviews in J9, 418 and J10, 368.

Glauert, A. M. (Ed.): ElECTRON MICROSCOPY 1972. (Inst. of Physics, London, 1972). Congr. proc.

Goldstein, J. et al.: SCANNING ELECTRON MICROSCOPY AND XRAY ANALYSIS. (Plenum, 1981).

Goringe, M. J. (Ed.): ElECTRON MICROSCOPY AND ANALYSIS. (Inst. of Physics, London, 1981). Conf. proc.

Grundy, P. J. \& Jones, G. A.: Electron microscopy IN THE STUDY OF: MATERIALS. (Arnold, 1976). Review in J10, 509.

Hawkes, P. W. (Ed.): COMPUTER PROCESSING OF EM IMAGES. (Springer, 1980). Review in A37, 606.

Head, A. K. et al:: Computed eleCtron MICROGRAPHS AND DEFECT IDENTIFICATION. (N. Holland, 1973). Review in A30, 605 .

Hearle, J. W. S., Sparrow, J. T. et al:: THE USE OF THE SCANNING ELECTRON MICROSCOPE. (Pergamon, 1972). Review in $\mathrm{J} 7,513$.

Heymann, P.: ThÉORIE dyNAMIQUe DE LA MICROSCOPIE ET DIFFRACTION ÉleCtroniQUe. (PUF, Paris, 1974).

Hoppe, W. \& Mason, R. (Eds.): UnCONVENTIONAL EleCtron MICROSCOPY FOR MOLECULAR STRUCTURE DETERMINATION. (Vieweg, 1979). This is Vol. 7 of the series Advances IN STRUCTURAL RESEARCH BY DIFFRACTION METHODS (earlier Vols. of which are listed in 4. Diffraction Theory). Review in B36, 2509.

Hornbogen, E.: Durchstrahlungs-Elek tronenMikroscoPIE FESTER STOFFe. (Verlag Chemie, 1971).
Johari, O. et al. (Eds.): SEM/1976, SEM/1977, SEM/1978, SEM/1979 and SEM/1980. (Published by SEM Inc, ILL 60666, USA, each production appearing just a year after the date in its title. The annual publication consists, now, of three separate parts: Part 3 is biological). These conf. proc. form a most voluminous and detailed survey of SEM and its applications. It now refers to itself as 'an international journal of SEM'. Reviews in A34, 478; J12, 640; J13, 463; and (SEM/1980) J15, 139.

Kihlborg, L. (Ed.): DiRECT IMAGING OF ATOMS IN CRYSTALS AND MOLECULES. (Royal Swedish Academy of Sciences, 1979). Review in A36, 835.

Kosevich, V. M. \& Palatnik, L. S.: Electron MicroscopIC IMAGES OF DISLOCATIONS AND PACKING DEFECTS: A PRACTICAL GUIDE. (in Russian) (Nauka, 1976).

Loretto, M. H. \& Smallman, R. E.: DefECt ANALysis IN ELECTRON MICROSCOPY. (Chapman \& Hall, 1975).

Misell, D. L. (Ed.): Developments IN ELECTRON MICROSCOPY AND ANALYSIS. (Inst. of Physics, London, 1977). Review in J12, 319.

Mulvey, T. (Ed.): ELECTRON MICROSCOPY AND ANALYSIS. (Inst. of Physics, London, 1980). Conf. proc. Review in J14, 218.

Nixon, W. C. (Ed.): EleCtron microscopy and aNalysis (Inst. of Physics, London, 1971). Conf. proc. For the latest in this series, see Goringe, above.

Nixon, W. C. (Ed.): SCANNING ELECTRON MICROSCOPY: SYSTEMS AND APPLICATIONS. (Inst. of Physics, London, 1973) Conf. proc.

Spence, J. C. H.: EXPERIMENTAL hIGH-RESOLUTION LleCTRON MICROSCOPY. (CUP, 1981).

Venables, J. A. (Ed.): Developments in electron microsCOPY AND ANALYSIS. (Academic Press, 1976).

Wenk, H. R. (Ed.): ELECTRON MICROSCOPY IN MINERALOGY. (Springer, 1976)

\section{General Crystallography}

Amigó, J. M. et al.: Cristalografía. (in Spanish). (Editorial Rueda, Madrid, 1981).

Amorós, J. L.: El CRistal. (Ed Urania, Barcelona, 1975).

Barrett, C. S. \& Massalski, T. B.: STRUCTURE OF METALS: CRYSTALLOGRAPHIC METHODS, PRINCIPLES AND DATA, 3rd revised ed. (Pergamon, 1980). Highly recommended; the flexicover edition is especially good value.

Bautsch, H.-J., Bohm, J. \& Kleber, I.: EINFÜHRUNG IN DIE Kristallographie. (VEB Verlag, 1977).

Bazarov, J. P.: Statistical theORY OF THE CRYSTAlline. STATE. (in Russian) (Nauka, 1972).

Bloss, F. D.: CRystallography and CRYSTAL CHEMISTRY: AN INTroduction. (Holt-Saunders, 1971).

Bohm, J.: Kristalle. (VEB Verlag, 1975; 2nd ed., 1977). Review, in English, in A33, 525.

Borchardt-Ott, W.: KRISTAllographIE: EINE EINFÜhiRUNG FÜr NATURWISSENSCHAFTLER. (Springer, 1976). Review, in German, in B33, 2988.

Brown, J. G.: X-RAYS AND THEIR APpliCations. (Plenum, 1975; however, this is merely a paperback reprint of the Iliffe edition of 1966).

Brown, P. J. \& Forsyth, J. B.: The Crystal structure of SOLIDS. (Arnold, 1973).

Buerger, M. J.: CONTEMPORARY CRYSTALlOGRAPHY. (McGraw-Hill, 1970). Review in B27, 866. 
Buerger, M. J.: KRISTAllogRAPHIE: EINE EINFÜHRUNG IN DIE GEOMETRISCHE UND RÖNTGENOGRAPHISCHE KRISTALLKUNDE. (de Gruyter, 1977). This is essentially a translation of the English book, above.

Buerger, M. J.: X-RAY CRYSTAllography. (Krieger, NY, 1980). This is a reprint of the well-known book of 1942 , still good value.

Chemical Society of Japan (Ed.): NEW HANDBOOK OF EXPERIMENTAL CHEMISTRY, Vol. 6: STRUCTURE ANALysis. (in Japanese). (Maruzen, 1977).

Chojnacki, J.: ElEMENTS OF PHYSICAL AND CHEMICAL CRYSTAllography. (in Polish) (PWM, Warsaw, 1973). Also available in Czech translation (Akademia, Praha, 1979).

Cullity, B. D.: Elements of X-RAY DIFFraction. (Addison Wesley, 1978). This book is the up-dated version of Cullity's book of 1956 (Review in Acta, 10, 389); it is addressed, apparently, just to metallurgists: not really a general book.

Dent Glasser, L. S.: CRYSTAllography AND ITS APPLICATIONS. (Van Nostrand, 1977). A highly recommended text. (A new edition is in preparation). Review in B34, 1750.

Dunitz, J. D.: X-RAY ANALYSIS AND THE STRUCTURE OF ORGaniC MOlecules. (Cornell Univ. Press, 1979). Addressed to the organic chemist, this book is the sequel to J. M. Robertson's well known 'ORGaniC CRYSTALS AND MOLECULES' of 1953. Review in B37, 493.

Gay, P.: The Crystalline State. (Oliver \& Boyd, 1972). Review, in German, in A29, 218.

Glusker, J. P. \& Trueblood, K. N.: CRystal Structure ANALYSIS: A PRIMER. (OUP, 1972). An easy-to-read book; almost non-mathematical. This has been translated into Russian (MIR, 1974) and into Polish (PWN, Warsaw, 1977).

Habermehl, G. et al.: RÖNTGENSTRUKTURANAL YSE ORGANISCHER VERBINDUNGEN: EINE EINFÜHRUNG. (Springer, 1973).

Haussühl, S.: Reihe Kristallographie, Band I, KristallGEOMETRIE (1977); Band 2, KRISTALLSTRUKTURBestimMUNG (1979). (Verlag Chemie).

Hudson, M.: CRystals and CRYstal structure. (Longman, 1971).

Jeffery, J. W.: METHODS IN X-RAY CRYSTALlOGraPhy. (Academic Press, 1971). Review in A28, 476.

Jost, K.-H.: Röntgenbeugung an Kristallen. (Akademie Verlag, 1975). Review, in English, in A32, 749.

Kakudo, M. \& Sasada, Y.: Introduction to X-Ray analysIS, 2nd ed. (in Japanese) (Tokyo Kagaku Dojin, 1973).

Kakudo, M. et al:: X-RAY CRYSTAL ANALYSIS; PRINCIPLES AND PRACTICE. (in Japanese) (Tokyo Kagaku Dojin, 1978).

Kitaigorodskii, A. I.: MoleCUlAR CRYSTALS AND MOLECULES. (Academic Press, 1973). A unique and fascinating book. Also available in Polish translation (PWN, Warsaw, 1976).

Kitaigorodskii, A. I.: Molekülkristalle. (Akademie Verlag, 1979). Review, in German, in B36, 2194.

Kleber, W.: EINFührung IN die KRISTAllographiE. (VEB Verlag, 1977). This is the latest (13th) edition of this well known German text. There is an English version, dated 1970, reviewed in A28, 221.

Komjak, N. I. et al. (Eds.): ApParatus AND METHODS of XRAY ANALYSIS. (in Russian) (Nauka). This is a continuing series. The latest issue, Vol. 25 (1981), has Komjak as principal editor; included among the 'college' of six editors are Umanskij and Kheiker.

Krischner, H.: EINFÜHRUNG IN DIE RÖNTGENFEINSTRUKTURANALYSE. (Vieweg, 1974).

Ladd, M. F. C. \& Palmer, R. A.: Structure determination BY X-RAY CRYSTALlOGRAPHY. (Plenum, 1977). Review in B34, 1400

Lieber, W.: Kristalle. (Christian Weise Verlag, München, 1977).

Lieber, W.: Kristalle UnTer der LuPE. (Ott Verlag, Thun, 1972).

Lipson, H.: Crystals AND X-RAYs. (Wykeham, 1970). Review in A27, 507.

Lipson, H. \& Steeple, H.: InTER PRETATION OF X-RAY POWDER DIFFRACTION PATTERNS. (Macmillan, 1970). Review in J5, 146.

Luger, P.: MOdern X-RAY analysis ON SINGLE CR YSTALS. (de Gruyter, 1980). Strongly recommended by the review: B37, 492.

McKie, D. \& McKie, C.: Crystalline solins. (Nelson, 1974). A good general textbook on the structure and physics of the crystalline state.

Mannami, M.: Crystallography for material sciences. (in Japanese). (Seibundo Shinkosha, 1972).

Meyer, K.: Physikalisch-Chemische Kristallographie. (VEB Deutscher Verlag f. Grundstoffindustrie, 1977).

Milburn, G. H. W.: X-RAY CRYSTALlOGRAPHY. (Butterworth, 1973). Review in A29, 583.

Miravitlles, L.: Cristalografía GeométriCa. (CEU Esplugues de Llobregat, 1976).

Mongiorgi, R.: I CRistalli nella scuola e nella vita. (G. Barchigiani Editore, Bologna, 1981).

Quinn, T. F. J.: X-RAYS, Electrons and CRYSTAlline MATERIALS. (Butterworth, 1970).

Raaz, F.: RöntgenkristallographIE. (de Gruyter, 1975).

Rigault, G.: INTRODUZIONE ALIA CRISTALLOGRAFIA. (Libreria Editrice Levrotto e Bella Universitaria Torino, 1976).

Sands, D. E.: InTROduction to CRYSTALlography. (Benja$\min , 1975$ ).

Schumann, H.: Kristall-GeOMETRIE: EINFüHRUNG IN DIE THEORIE DER GITTERTRANSFORMATIONEN IN METALLISCHER WerkstofFe. (VEB Deutscher Verlag f. Grundstoffindustrie, 1980).

Schwartz, L. H. \& Cohen, J. B.: Diffraction From Materials. (Academic Press, 1977). Review in J11, 719.

Shaskol'skaya, M. P.: CRYSTAllograPhy. (in Russian). (Vysshaya Shkola, 1976). Review, in English, in J12, 139.

Shaskol'skaya, M. P.: Crystals. (in Russian). (Nauka, 1978). Review, in English, in A36, 157.

Shaskol'skaya, M. P.: EsSAys ON THE PROPERTIES OF CRYSTALS. (in Russian). (Nauka, 1978). Review, in English, in J13, 200.

Sherwood, D.: CRystals, X-RAYS AND PRoteins. (Longman, 1976). An unusually disappointing book. Review in B32, 2732.

Srinivasan, R. (Ed.): AdVANCES IN CRYSTALlOGRAPHY. (OXford \& IBH, New Delhi, 1978).

Steadman, R.: Crystallography. (Van Nostrand, 1982). An inexpensive, step-by-step paperback, full of diagrams and exercises on XRD and ED for materials science students.

Stout, G. H. \& Jensen, L. H.: X-RAY STRUCTURE DETERMINA- 
TION. (Macmillan, 1972). Originally published in 1968 but still much in use, this is the 5 th printing of this classic.

Trotter, J. et al. (Eds.): STRuCTURE REPORTS. This authoritative annual presentation of crystal structures has been produced for the IUCr by various editors, most recently W. B. Pearson and J. Trotter (the editorship is currently passing to G. Ferguson). A greater than usual number of volumes has been produced during the past decade, including the 60-YEAR INDEX (1913-1973), published in 1975. The publisher is now Reidel, Dordrecht, The Netherlands. Review in A35, 346 and B34, 3847.

Umanskij, M. M.: X-RAY STRUCTURE ANALYSIS: A BIBLIOGRAPHY. (in Russian). (Leningrad Scientific Publ. Co., 1978). Review, in English, in A35, 510.

Umanskij, M. M. \& Zolina, Z. K.: COLLECTED wORKS IN XRAY STRUCTURE ANALYSIS. (Moscow Univ., 1975).

Vainshtein, B. K. et al:: MODER N CRYSTALlograpHy, Vols. 1, 2, 3, and 4. This is being published first in Russian: Vols. 1, 2 and 3 are in print (Nauka, 1980); Vol. 4 is expected (Nauka, 1981). Meantime, Vols. 1 and 2 have already appeared in English (Springer, 1981) and the remaining Vols. have been announced (Springer, 1982). Although Vainshtein is the principal author of this series, the authors of Vol. 3 are Chernov, A. A. et al., and of Vol. 4, Shuvalov, L. A. et al. Review of Vol. 1, in English, in A36, 1095.

Van Meersche, M. \& Feneau-Dupont, J.: InTroduction d LA CRISTALlOGRAPHIE ET $\dot{A}$ LA CHIMIE STRUCTURALE. (Oyez, 1976).

Weigel, D.: Cristallographie et STRuCture des SOlides: VOI. 1, AlgEbre ET GÉOMÉTRIE CRISTALliNe ET MOLÉCULAIRE. (Masson, 1972).

Wilson, A. J. C.: Elements of X-RAY CRYSTallography. (Addison Wesley, 1970). Review in A27, 190.

Wölfel, E. R.: TheORIE Und PRAXIS DeR RöntgenstrukTURANALYSE. (Vieweg, 1975). This book has no index.

Woolfson, M. M.: INTROdUCTION TO X-RAY CRYSTALlOGRAPHY. (CUP, 1978). This is the paperback reprint of the successful book of 1970, reviewed in A26, 461.

Wormald, J.: Diffraction methods. (OUP, 1973). Review in B30, 842.

Zhdanov, G. S. et al:: Diffraction ANd Resonance ANAlySIS. (in Russian) (Nauka, 1980). Review, in English, in A37, 944.

\section{History}

Amorós, J. L.: La gran aventura del Cristal. (Ed Univ Complutense, Madrid, 1978).

Bernal, J. D.: THE ANALYTIC THEORY OF POINT SYSTEMS. This is a collector's item: Bernal's first scientific paper, never published, but now available from Dr A. L. Mackay, Birkbeck College, London.

Bijvoet, J. M., Burgers, W. G. \& Hägg, G.: EARLY PAPERS ON THE DIFFRACTION OF X-RAYS BY CRYSTALS, Vols. 1 (1969) and 2 (1972). These contain extracts from about 170 papers in the period 1912-1934; published originally by Bohn, Scheltema \& Holkema, they are now obtainable from Reidel, Dordrecht, The Netherlands or Polycrystal Book Service, Chicago, USA.

Bragg, W. L. (edited by Phillips, D. C. \& Lipson, H.): ThE
DEVELOPMENT OF X-RAY ANALYSIS. (Bell, 1975). Review in A32, 748, and J9, 260.

Bravais, A.: COLlECTED SCIENTIFIC PAPERS: CRYSTALLOGRAPHIC STUDIES. (Russian translation from French) (Nauka, Leningrad, 1974).

Caroe, G. M.: William Henry BragG, 1862-1942. (CUP, 1978). The author, Caroe, was the daughter of $\mathrm{W} . \mathrm{H}$. Bragg. This book is delightfully reviewed in A35, 1086 and B35, 2476 .

Glusker, J. P. (Ed.): STRUCTURAL CRYSTAllograPHY IN CHEMISTRY AND BIOLOGY. (Vol. 4 in the series of BENCHMARK PAPERS IN PHYSICS \& CHEMISTRY, by Hutchinson Ross/Academic Press, 1981). This is a beautifully produced book, with interesting editorial comments on the various 'benchmark' papers that are reproduced.

Goodman, P. (Ed.): FIFTY YEARS OF ELECTRON DIFFRACTION. (Reidel, 1981). This record of the discovery and development of ED (which should not be confused with the book by Dobson, entitled 'ElECTRON DIFFRACTION, 1927-1977', which is not a history of the subject) was commissioned by the IUCr, and is remarkable for the number and eminence of its contributing authors.

Hodgkin, D. C:: Kathleen Lonsdale: a biographical MEMOIR. (Royal Society of London, 1975). This is a reprint from the Royal SOCIETy's BIOGRaPHICAL MEMOIRS OF Fellows; this particular biography is available separately, directly from the Society. Two other recent memoirs are of special interest to crystallographers, that of $W$. L. Bragg, by D. C. Phillips (1979), and that of J. D. Bernal, by D. C. Hodgkin (1980); but it should be noted that these latter are not available as separately bound items.

McLachlan, D. \& Glusker, J. P. (Eds.): CRYstallograPhy IN North AMERICA. (American Crystallographic Association, 1982).

Schneer, C. J. (Ed.): CRYSTAL FORM AND STRUCTURE: BENCHMARK PAPERS. (Wiley, 1977). Review in A34, 349.

Shafranovskii, I. I.: HISTORY OF CRYSTALLOGRAPHY. (in Russian) (Nauka, 1978). An unusually interesting history, up to the time of the discovery of X-ray diffraction. Review in A38, 288.

Slater, J. C.: SOLID STATE AND MOLECULAR THEORY: A SCIENTIFIC BIOGRAPHY. (Wiley, 1975).

Watson, J. D.: THE Double helix. (Penguin - first published in 1968 but reprinted many times since then). This is Watson's personal account of the discovery of the structure of DNA.

It may be added that P. P. Ewald's monumental and definitive work, FIFTY YEARS OF X-RAY DIFFraction, published for and dedicated to the IUCr, in 1962, is still available, from Reidel or Polycrystal.

\section{Industrial Crystallography/Metals/X-ray Spectrometry}

Agarwal, B. K.: X-RAY SPECTROSCOPY. (Springer, 1979).

American Society for Metals: Phase transformations and RELATED PHENOMENA IN STEELS. (American Society for Metals, Ohio, 1973).

Andrews, K. W.: PhysiCal metallurgy: TeChNiQues AND aPPlications, Vols. 1 and 2. (Allen \& Unwin, 1973). 
Azaroff, L. V.: X-RAY SPECTROSCOPY. (McGraw-Hill, 1974). Review in J9, 259.

Barrett, C. S. \& Massalski, T. B.: Structure of metals: CRYSTALLOGRAPHIC METHODS, PRINCIPLES AND DATA, 3rd revised ed. (Pergamon, 1980).

Barrett, C. S. et al. (Eds.): Advances in X-RAy analysis. (Plenum). This continuing series, which appears annually, being the proceedings of the annual Denver conference, has now reached Vol. 25 (1982); there have been a number of other principal editors, including, for recent volumes, Gould, R. W., McMurdie, H. F., McCarthy, G. J. and Smith, D. K. Reviews of Vols. 19-22 and 24 in J10, 367; J11, 64; J12, 488; J13, 462; and J15, 359.

Bernshtejn, M. L. \& Zaimovskii, V. A.: STRUCtURE AND MECHANICAL PROPERTIES OF METALS. (in Polish) (WNT, Warsaw, 1973). This is a translation from the original Russian.

Bertin, E. P.: Principles and practice of X-Ray spectroMETRIC ANALYSIS. (Plenum, 1970). Review in J5, 387.

Bojarski, Z. \& Bold, T.: APPlied CRYstallography. (Katowice, 1978). Conf. proc.

Caglioti, G.: INTROduzione alla fisica deI MATERIali (INTRODUCTION TO THE PHYSICS OF ENGINEERING MATERIALS). (in Italian) (Zanchelli, Bologna, 1974). Review, in English, in A33, 347.

Caglioti, G. (Ed.): Atomic structure AND MECHANiCAL PRoperties of metals. (N. Holland, 1976). Conf. proc.

Christian, J. W.: THE THEORY OF TRANSFORMATIONS IN METALS AND ALloYs, 2nd ed. (Pergamon, 1975).

Clarke, P. T.: STANDARD STEREOGRams FOR MATERIals SCIENCE. (HMSO, London, 1976). The reviewer did not think this a useful publication: J10, 509.

Cotterill, P.\& Mould, P. R.: Recrystallisation and grain GROWTH OF METALS. (Surrey Univ., Brighton, UK, 1976).

Coulomb, P.: Les teXtures dans les MÉTEAUX DE RESEAU CUBIQUE. (Polish translation) (PWN, Warsaw, 1971).

Cullity, B. D.: Elements of X-Ray diffraction. (Addison Wesley, 1978). This is a textbook addressed to metallurgists.

Damask, A. C. \& Dienes, G. J.: Point defects in metals. (Gordon \& Breach, 1971).

Finkel, V. A.: Low tem PER A TURE X-RAY CRYSTallography OF METALS. (in Russian) (Metallurgija, 1971).

Finkel, V. A.: Structure of Rare-Earth metals. (in Russian) (Metallurgija, 1978).

Finniston, H. M. (Ed.): Structural characteristics of METALS. (Elsevier, 1971).

Frank-Kamenetskij, V. A. (Ed.): HANDBOOK FOR THE X-RAY INVESTIGATION OF MINERALS. (in Russian). (Nedra, 1975). Review, in English, in J9, 514.

Gleiter, H.: Struktur und Eigenschaften von GrossWINKELKORNGRENZEN IN METALLEN. (Borntraeger, Berlin, 1972).

Glocker, R.: MATERIALPRÜFUnG MIT RÖNTGENSTRAhLEN. (Springer, 1971). Review in A28, 95.

Gorczycz, S. (Ed.): CRystallisation of CAST alloys. (in Polish) (Ossolineum, Warsaw, 1980).

Gorelik, S.: RECRYSTALLISATION IN METALS AND ALloys. (MIR, 1981).

Haessner, F.: Recrystallisation of metallic Materials. 2nd ed. (Dr Riederer Verlag, Stuttgart, 1978).
Honeycombe, R. W. K.: The plastic Deformation of METALS. (Arnold, 1974).

Jenkins, R., Gould, R. W. \& Gedcke, D.: Quantitative XRAY SPECTROMETRY. (Dekker, 1981). Review in J15, 360.

Jenkins, R. \& de Vries, J. L.: Practical X-RAY SPECTROMETRY, 2nd ed. (Macmillan, 1970). Review in J4, 91.

Jenkins, R. \& de Vries, J. L.: WORKED EXAMPLES IN X-RAY SPECTROMETRY, 2nd ed. (Macmillan, 1977).

Jong, E. J. de \& Jančić, S. J. (Eds.): INdustrial CRYSTALliSATION, 78. (N. Holland, 1979). Review in J13, 463.

Kauczor, E.: Metall Unter dem Mikroskop. (Springer, 1974).

Kimura, H. \& Maddin, R.: Quench haRdening in METALS. (N. Holland, 1971). Review in J5, 443. Also available in Russian translation (MIR, 1977).

Krishtal, M. A. \& Golovin, S. A.: InNer friction AND STRUCTURE OF METALS. (in Russian) (Metallurgija, 1976).

Lakhtin, Yu.: ENGINEERING PHYSICAL METALlURGY AND HEAT TREATMENT. (MIR, 1980). This is a revised translation from the Russian; however, it is definitely not recommended by the review: B36, 2509.

Lipson, H. \& Steeple, H.: InTER PRFtation OF X-RAY POWDER DIFFRACTION PATTERNS. (Macmillan, 1970). Review in J5, 146.

Martin, J. W. \& Doherty, R. D.: Stabllity OF MICROSTRUCTURE IN METALLIC SYSTEMS. (CUP, 1976). Also in Russian translation (Atomizdat, 1978).

Mullin, J. W. (Ed.): Industrial CRYSTALlisation. (Plenum, 1976). Review in $\mathbf{J 1 0}, 508$.

Nishiyama, Z.: MARTENSITIC TRANSFORMATION. (Academic Press, 1978).

Nyvlt, J.: Industrial CRystallisation. (Verlag Chemie, 1978). Review in J12, 320. See also J5, 442, for a review, in German, of this author's book of 1971 on INDUSTRIAL CRYSTALLISATION FROM SOLUTIONS.

Olejnik, S. (Ed.): Applied X-Ray CRystallography. (in Polish) (PWN, Warsaw, 1976). Papers of the Committee of Crystallography, Polish Academy of Science.

Pawlowski, K.: Structural investigations of Industrial GRAPHITES. (Ossolineum, Warsaw, 1980). See also Kelly, in 2. Crystal Physics.

Pearson, W. B.: The CRystal Chemistry and PHysics of metals AND alloys. (Wiley, 1972).

Petzow, G.: Metallographisches Ätzen. (Borntraeger, Berlin, 1976).

Scheer, L.: WaS IST STahl? (15 Aufl, bearbeitet von $\mathbf{H}$. Berns). (Springer, 1980).

Schulze, G. E. R.: Metallphysik. (Springer, 1974). Review, in English, in J8, 698.

Schumann, H.: KRISTAll-GEOMETRIE: EINFÜHRUNG IN DIE THEORIE DER GITTERTRANSFORMATIONEN IN METALLISCHER WERKSTOFFE. (VEB Deutscher Verlag f. Grundstoffindustrie, 1980).

Schumann, H.: MetallographiE. (VEB Deutscher Verlag f. Grundstoffindustrie, 1974).

Warlimont, H. (Ed.): ORDER-DISORDER TRANSFORMATIONS IN ALlOYS. (Springer, 1974). Symp. proc.

Wood, W. A.: THE STUDY OF METAL STRUCTURES AND THEIR MECHANICAL PROPERTIES. (Pergamon, 1971).

Wyryll, C. J.: ThE THEORY OF TRANSFORMATIONS IN METALS AND ALloYs. (Pergamon, 1975). 


\section{Liquid Crystals}

Adamczyk, A. \& Strugalski, Z.: Liquid CRYSTALS. (in Polish) (WNT, Warsaw, 1976). This is a booklet for non-specialists.

Bata, L. (Ed.): AdVANCES IN LIQUID CRYSTAL RESEARCH AND APPliCations. (Pergamon, 1981). This is the proceedings of 'the third liquid crystal conference of the socialist countries, Budapest'.

Brown, G. H. (Ed.): AdvanCES IN Liquid CRYSTALS, Vols. 1 (1975), 2 (1976), 3 (1978) and 4 (1980) (Academic Press). Review of Vol. 1 in A33, 252 and of Vol. 4 in A38, 173.

Brown, G. H. \& Labes, M. M.: Liquid CR YSTALS. (Gordon \& Breach, 1972). This is the 3rd Vol. of a series which began in 1967.

Brown, G. H. \& Walker, J. J.: LIQUID CRYSTALS AND BIOLOGICAl STRuCTURes. (Academic Press, 1979).

Chandrasekhar, S.: LiQUID CRYSTALS. (CUP, 1977). This excellent textbook on liquid crystals is now also available in paperback (CUP, 1980). Review in A34, 351.

Chandrasekhar, S. (Ed.): LiQuid CRYSTALS. (Indian Academy of Sciences, Bangalore, 1975). The report of an int. conf. Review in A33, 251.

Demus, D. \& Richter, L.: Textures OF Liquid CRYSTALS. (Verlag Chemie, 1978). Review in B36, 2193. A 2nd ed. of this book is now available (1980).

Demus, D. et al:: Flüssige Kristalle in Tabellen, 2 Aufl. (VEB Deutscher Verlag f. Grundstoffindustrie, 1976).

Gennes, P. G. de: The PHysics OF LIQUid CRystals. (OUP, 1974). Review in J9, 186

Gray, G. W. \& Goodby, J. W.: LIQUid CRYSTALS: IDENTIFICATION, CLASSIFICATION AND STRUCTURE. (Pergamon, 1981). This book includes approximately 100 colour photomicrographs of typical textures.

Gray, G. W. \& Winsor, P. A.: LIQuid CRYSTALS AND PlastiC CRYSTALS, Vols. 1 and 2. (Horwood, 1974). See also Sherwood, in 18. Miscellaneous.

Helfrich, W. \& Heppke, G.: LIQUID CRYSTALS OF ONE-AND TWO-DIMENSIONAL ORDER. (Springer, 1980). Review in B38, 348.

Jeu, W. H. de: Physical PRoperties of liquid CRYSTALline MATERIALS. (Gordon \& Breach, 1980). A small, rather limited survey.

Johnson, J. F. \& Porter, R. S. (Eds.): Liquid CRYSTALS AND ORDERED FLuIDS, Vols. 1, 2 and 3. (Plenum, 1970, 1974 and 1978).

Kallard, T.: Liquid CRYSTAL DEVICES. (Optosonic Press, NY, 1973).

Kelker, H. \& Hatz, R.: HANDBOOK OF LIQUID CRYSTALS. (Verlag Chemie, 1980). Highly recommended by the review. However, this is an unusually expensive book (DM 420). Review in B36, 2861.

Khetrapal, C. L. et al.: LyOTROPIC LIQUID CRYSTALS. (Springer, 1975). Review in A33, 252.

Kléman, M.: PoINTS, LIGNES, PAROIS DANS LES fluides ANISOTROPES ET LES SOLIDES CRISTALLINS, Vols. 1 and 2. (Zone Industrielle de Courtaboeuf, 1977).

Liebert, L. (Ed.): LIQUID CRYSTALS. (Academic Press, 1978). A collection of reviews.

Luckhurst, G. R. \& Gray, G. W. (Eds.): The MOLECUlaR PHYSICS OF LIQUID CRYSTALS. (Academic Press, 1979). Review in A37, 139.
Meier, G., Sackmann, E. \& Grabmaier, J. G.: ApPliCATIONS OF LIQUID CRYSTALS. (Springer, 1975). Review in J9, 418.

Priestley, E. B. et al. (Eds.): INTRODUCTION TO LIQUID CRYSTALS. (Plenum, 1974).

Saeva, F. D. (Ed.): LIQUID CRYSTALS, THE FOURTH STATE OF MATTER. (Dekker, 1979). Review in A37, 607.

Sprokel, G. J. (Ed.): THE PHYSICS AND CHEMISTRY OF LIQUID CRYSTAL DEVICES. (Plenum, 1980). Proc. symp. at IBM, California. Review in A37, 448.

Stegemeyer, H.: Flüssige Kristalle: Struktur, EigenSCHAFTEN UND BEDEUTUNG. (Westdeutscher Verlag, 1977).

Zhdanov, S. I. (Ed.): LIQUID CRYSTAL CHEMISTRY AND PHYSICS. (Pergamon, 1981).

Zhdanov, S. I. (Ed.): LIQUid CRYSTALS. (in Russian) (Khimia, 1979).

\section{Materials and their Properties/ General Materials Science}

Amelinckx, S. et al. (Eds.): DifFraction AND IMAGING TECHNIQUES IN MATERIALS SCIENCE. (N. Holland, 1978) Review in J13, 107.

Anderson, J. C. et al.: Materials science, 2 nd revised ed. (Nelson, 1974). This is mostly concerned with mechanical and metallurgical properties.

Bernshtejn, M. L. \& Zaimovskii, V. A.: Structure and MECHANICAL PROPERTIES OF METALS. (in Polish) (WNT, Warsaw, 1973). Translation from Russian.

Booth, G.: Magnetism IN METAllic Materials. (Pergamon, 1979).

Brostow, W.: SCIENCE of MAterials. (Wiley, 1979). A good general text.

Burke, J. J. \& Weiss, V. (Eds.): Nondestructive EvaluaTION OF MATERIALS. (Plenum, 1979). Proc. of a 'Sagamore Army Materials' conf. Review in J15, 470.

Burns, G. \& Glazer, A. M.: Space Groups for solid STATE SCIENTISTS. (Academic Press, 1978). Review in J12, 428.

Burstein, E. (Ed.): ATOMIC STRUCTURE AND PROPERTIES OF SOLIDS. (Academic Press, 1973).

Burton, B.: Diffusional CREeP OF POLYCRystalline MATERIALS. (Trans. Tech., 1977).

Chanda, M.: SCIENCE of ENGiNEering Materials, Vol. 1: Structure of MatTer, Vol. 2: Materials and Vol. 3: ENGINEERING PROPERTIES. (Macmillan, 1981).

Chaudhari, P. \& Matthews, J. W. Grain boundaries AND INTERFACES. (N. Holland, 1972).

Chen, C.-W.: Magnetism and MEtallurgy of SOFT MaGNETIC MATERIALS. (N. Holland, 1977). Review in A35, 345.

Cullity, B. D.: ElEments of X-RAY DIFFraction, (Addison Wesley, 1978). For metallurgists.

Davidge, R. W: Mechanical behaviour of CERAmics. (CUP, 1979).

Davies, G. J. (Ed.): TEXTURE AND PROPERTIES OF MATERIALS. (Multiplex, London, 1976). Conf. proc.

Dreyer, W.: Materialverhalten anisotroper FestKörPER. (Springer, 1974).

Eitel, W.: INDUSTRIAL GLASS: GLASS AND ENAMELS. (Academic Press, 1976). See also Götz in 18. Miscellaneous.

Eitel, W.: SiliCATE STRUCTURE AND DISPERSOID SYSTEMS. (Academic Press, 1975).

Finniston, H. M. (Ed.): Structural Characteristics of MATERIALS. (Elsevier, 1971). 
Fradin, F. Y. (Ed.): EleCtronic STRUCTURE AND PROPERTIES OF MATerials. (Academic Press, 1981).

Freyhardt, H. C. (Ed.): CR ystals: GrowTH, PROPERTIES AND APPLICATIONS, Vols. 2, 3 and 4. (Springer, 1980, 1980 and 1981). Freyhardt is the managing editor of this series, which now runs to a sixth volume. For Vol. 1, see Rooijmanns; for Vol. 5, see Grabmaier. Review of Vol. 4 in A38, 397.

Gottstein, G. \& Lucke, K. (Eds.): Textures of Materials. (Berlin, 1978). Conf. proc.

Grabmaier, J. (Ed.): Silicon (Vol. 5 of CRYSTals: GROWTH, PROPERTIES AND APPLICATIONS). (Springer, 1981). The managing editor of this series is Freyhardt; earlier volumes are listed under that name.

Guy, A. Gr: Essentials of materials science. (McGrawHill, 1976). An attractive student text, which gives much attention to practical applications. Available also in Polish translation (PWN, Warsaw, 1977).

Hornbogen, E.: Werkstoffe: Aufbau und Eigenschaften. (Springer, 1973).

Hulliger, F.: Structural CHEMISTRY OF LAYER TYPE PHASES. (Reidel, 1977). This is Vol. 5 of Reidel's series of seven volumes on layered materials; for the others, see Lee, Levy, Lieth and Wieting, both in this section, and in 25 . Solid State Chemistry. Review of this Vol. in B35, 793.

International Atomic Energy Agency (IAEA): PHYsics of MODERN MATERIALS, Vols. 1 and 2. (IAEA, Vienna, 1980). Lectures presented at a symposium in Trieste, 1978.

Kaldis, E. (Ed.): CURRENT topiCS IN MATERIALS SCIENCE, Vols. 1 (1978), 2 (1977), 3 (1979), 4, 5 and 6 (1980) and 7 (1981). (N. Holland). This review series deals with very varied topics, with emphasis on electronic materials. Reviews of Vols. 1, 2, 3, and 4 in J13, 107; J11, 673; J13, 636; and J13, 637; and of Vols. 5 and 6 in J15, 141.

Kao, K.-C. \& Hwang, W.: Electrical transport in SOLIDS. (Pergamon, 1979). Gives particular attention to organic semiconductors.

Kaufmann, E. N. \& Shenoy, G. K. (Eds.): NuCleAR AND ELECTRON RESONANCE SPECTROSCOPIES ALLIED TO MATERIALS SCIENCE. (N. Holland, 1981). Symp. proc.

Kelly, A.: Strengthening methods in CRystals. (Elsevier, 1971).

Kelly, A.: Strong solids. (OUP, 1973).

Kimura, H. \& Maddin, R.: QuenCH hardening in metals. (N. Holland, 1971). Review in J5, 443. Also available in Russian translation (MIR, 1977).

Krishnan, R. S. et al.: THERMAL EXPANSION OF CRYSTALS. (Pergamon, 1979). Warmly commended by the review: A37, 142 .

Lakhtin, Yu: ENGINEERING PHYSICAL METALlurgy AND HEAT TREATMENT. (MIR, 1980). Somewhat disparaged by the review: B36, 2509.

Lee, P. (Ed.): Optical and electrical properties (OH LAYERED MATERIALS). (Reidel, 1976). Review in A35, 347.

Lévy, F. (Ed.): CRYSTALlOGRAPHY AND CRYSTAL CHEMISTRY OF MATERIALS WITH LAYERED STRUCTURES. (Reidel, 1976). Review in B33, 2351.

Lieth, R. M. A. (Ed.): Preparation and Crystal Growth OF MATERIALS WITH LAYERED STRUCTURES. (Reidel, 1977). Review in B34, 3948.

MacCrone, R. K. (Ed.): Properties AND microstructure. (Academic Press, 1977).
Musgrave, M. J. P.: CRystal acoustics. (Holden Day, 1970). Review in A27, 699.

Nagakura, S.: STRuCTURE OF MATERIALS. (in Japanese). (Asakura Shoten, 1979).

Newnham, R. E.: STRUCTURE-PROPERTY RELATIONS. (Springer, 1975). Review in A32, 351.

Paufler, P. \& Schulze, G. E. R.: Physikalische GrundlaGEN MECHANisCher FESTKÖRPEREJGENSChafteN, Band 1 und 2. (Akademie-Verlag, 1978).

Petzow, G. \& Huppmann, W. J. (Eds.): Contemporary INORGANIC MATERIALS 1978. (Dr Riederer Verlag, Stuttgart, 1979).

Raghavan, V.: MATERIALS SCIENCE AND ENGINEERING, 2nd ed. (Prentice Hall, New Delhi, 1979).

Rao, E. C. S., et al:: EXPERIMENTS IN MATERIAL SCIENCE. (Tata McGraw-Hill, New Delhi, 1972).

Rooijmans, C. J. M.: CRYSTALS FOR MAGNETIC APPLICATIONS. (Springer, 1978). This is the first Vol. of a new series on CRYSTALS: GROWTH, PROPERTIES AND APPLICATIONS; for the 2nd and 3rd Vols., see Freyhardt, above. Review of this Vol. in J12, 642.

Schatt, W.: EINFÜHRUNG IN DIE WERKSTOFFWISSENSCHAFTEN, 2. Aufl. (VEB Deutscher Verlag f. Grundstoffindustrie, 1978).

Schlenker, B. R.: INTRODUCTION TO MATERIALS SCIENCE. (Wiley, 1974). This is the extensively revised Sl edition. Written from the standpoint of metallurgy and engineering, an excellent student text.

Schultz, J. M.: DifFRACTION FOR MATERIALS SCIENTISTS. (Prentice Hall, 1981). A comprehensive treatment.

Schulze, G. E. R.: Metallphysik. (Springer, 1974). Review, in English, in J8, 698 .

Schwartz, L. H. \& Cohen, J. B.: Diffraction From MATERIals. (Academic Press, 1977). Review in J11, 719.

Shaskol'skaya, M. P.: EsSAYS ON THE PROPERTIES OF CRYSTALS. (in Russian). (Nauka, 1978). Review, in English, in $\mathrm{J} 13,200$.

Sprackling, M. T.: The MEChaniCAl PROPERTIES OF MATTER. (English Univs. Press, 1972). Review in J6, 58.

Stüwe, H.-P.: Mechanische ANiSOTROPIE. (Springer, 1974).

Stüwe, H. P. \& Vibrans, G.: FeinstrukturuntersuchunGEN IN DER WERKSTOFFKUNDE. (Bibliographisches Inst., Mannheim, 1974).

Tomashpolsky, Yu. Ya. \& Platonov, G. L.: Ferroelectric FILMS OF METALLIC COMPLEX OXIDES. (in Russian). (Soviet Metallurgy, 1978). Review, in English, in J13, 636.

Touloukian, Y.S. \& Ho, C. Y.: MaSTER INDEX TO Materials AND PROPERTIES. (Plenum, 1979). This is the index-volume of the 13-volume series by these authors, with thermophysical properties of over 6000 materials.

Vlasov, A. G. (Ed.): INFRARED SPECTRA OF INORGANIC GLASSES AND CRYSTALS. (in Russian). (Chimija, Leningrad, 1972).

Vogel, W.: STRUKTUR UND KRISTALlisation vON GLÄSERN. (VEB Deutscher Verlag f. Grundstoffindustrie, 1971). See also Eitel, above, and Götz, in 18. Miscellaneous.

Wang, F. F. Y.: INTRODUCTION TO SOLID STATE ELECTRONICS. (N. Holland, 1979). Review in A37, 143.

Weber, H. W. (Ed.): ANISOTROPY EFFECTS IN SUPERCONDUCTORS. (Plenum, 1977). See 18. Miscellaneous (under Weber, and others) for more titles in this area.

Weber, H. W. \& Hittmair, O.: SupraleITUNG. (Verlag Karl Thiemig, 1979). Review, in English, in A36, 502. 
Wieting, T. J. \& Schülter, M.: Electrons And Phonons IN LAYERED CRYSTAL STRUCTURES. (Reidel, 1981?-announced but not yet materialised).

Wohlfarth, E. P. (Ed.): FerRomagnetic Materials: A HaNDBOOK ON THE PROPERTIES OF MAGNETICALLY ORDERED SUbSTANCES, Vols. 1 and 2. (N. Holland, 1980). Two further Vols. are projected.

Wooster, W. A.: TENSORS AND GROUP THEORY FOR THE PHYSICAL PROPERTIES OF CRYSTALS. (OUP, 1973).

Wooster, W. A. \& Bretton, A.: Experimental Crystal PHYSICS, 2nd ed. (OUP, 1970). An extremely practical book on the laboratory determination of physical properties. Review in J4, 401.

Note: A new journal, Materials Letters (N. Holland, 1982 - ). The principal editors are F. F. Y. Wang and J. H. Wernick.

\section{Materials/Electronics/Devices/Semiconductors}

Albany, J. H. (Ed.): DeFfCTS AND RADIATION EFFECTS IN SEMICONDUCTORS. (Inst. of Physics, London, 1979). Conf. proc.

Aleksandrov, L. N. \& Kuznetsov, T. A.: Processes of GROWTH AND SYNTHESIS OF SEMICONDUCTOR CRYSTALS AND FILMS. (in Russian). (Nauka, 1975).

Arnold, H.: Physikalische Chemie der Halbleiter. (Akademie-Verlag, 1978).

Ash, E. A. (Ed.): Solid state devices. (Inst. of Physics, London, 1978). Conf. proc.

Balkanski, M. (Ed.): HANDBOOK ON SEMICONDUCTORS, Vol. 2: OPTICAL PROPERTIES OF SOLIDS. (N. Holland, 1980). For Vols. 1, 3 and 4, see Paul, Keller and Hilsum, respectively, below. Review of this Vol. in J13, 637.

Beeforth, T. H. \& Goldsmid, H. J.: Physics OF sOlid STATE DEviCes. (Academic Press, 1970).

Beneking, H. (Ed.): Gallium aRSFNIDE AND RELATED COMPOUNDS. (Inst. of Physics, London, 1971). Proc. of the 3rd International Symposium on GaAs; for the most recent of these, see Sugano, below.

Blom, G. M. et al. (Eds.): Liquid phase epitaxy. (N. Holland, 1974). Review in J8, 697.

Bok, J. (Ed.): Gallium arSENIDE and RELATEd COMPOUNDS. (Inst. of Physics, London, 1975). Symp. proc.

Borisova, Z.: Glassy SEmiconductors. (Plenum, 1981).

Brodsky, M. H. (Ed.): AMORPHOUS SEMICONDUCTORS. (Springer, 1979). Review in A37, 446.

Carroll, J. E. (Ed.): Solid State Devices. (Inst. of Physics, London, 1981). Conf, proc.

Carter, G. \& Grant, W. A.: Ion implantation of SEmiconDUCTORS. (Arnold, 1976).

Close, K. J. \& Yarwood, J.: An introduction to SEmiconDUCTORS. (Heinemann, 1971).

Coles, B. R. \& Caplin, A. D.: The electronic structures OF SOL.IDS. (Arnold, 1976).

Conolly, T. F.: SEMICONDUCTORS: preparation, CRystal GROWTH AND SELECTED PROPERTIES. (PlenUm, 1972).

Coutts, T. et al. (Eds.): SOlAR CELlS: THEIR SCIENCE, TECHNOLOGY, APPLICATIONS AND ECONOMICS. (Elsevier Sequoia). This is a new journal, started in 1979.
Cullen, G. W. \& Wang, C. C. (Eds.): Heteroepitaxial SEMICONDUCTORS FOR ELECTRONIC DEVICES. (Springer, 1978). Review in J12, 319.

Cullen, G. W. et al. (Eds.): VAPOUR Growth AND EPITAXY. (N. Holland, 1975). Review in J10, 212.

Cullis, A. G. \& Joy, D. C. (Eds.): Microscopy of SEMiconDUCTING MATERIals. (Inst. of Physics, London, 1981).

Dalven, R.: INTRODUCTION TO APPLIED SOLID STATE PHYSICS: TOPICS IN THE APPLICATIONS OF SEMICONDUCTORS, SUPERCONDUCTORS, AND THE NONLINEAR OPTICAL PROPERTIES OF SOLIDS. (Plenum, 1980).

Ferry, D. K. et al. (Eds.): Physics of NONLINEAR TransPort IN SEMICONDUCTORS. (Plenum, 1980). Review in A37, 767.

Fraser, D. A.: THE PHYSICS OF SEMICONDUCTOR DEVICES. (OUP, 1979).

Freyhardt, H. C. (Ed.): CRYSTALS: GROWTH, PROPERTIES AND APpliCations, Vols. 2, 3, and 4. (Springer, 1980, 1980, and 1981). Freyhardt is the managing editor of this series, which particularly features electronic materjals, and which now runs to a sixth volume. For Vol. 1, see Rooijmanns, in 11. Materials and their Properties; for Vol. 5, see Grabmaier, below. Review of Vol. 4 in A38, 397.

Fridkin, V. M.: FerRoeleCtric SEMICONDUCtors. (Plenum, 1980). Translated from Russian. Review in A37, 447.

Fridkin, V. M.: Photoferroelectrics. (Springer, 1979). Review in A36, 1091.

Fumi, F. G. (Ed.): Physics of SEmiconductors. (N. Holland, 1976). Conf. proc.

Gorjunowa, N. A.: Halbleiter mit diamantähnliche Struk tur. (BSB B. G. Teubner Verlagsges., 1971).

Grabmaier, J. (Ed.): SILICON (Vol. 5 of CRYSTALS: GROWTH, PROPERTIES AND APPLICATIONS). (Springer, 1981). The managing editor of this series is Freyhardt; earlier volumes are listed under that name.

Guldberg, J. (Ed.): NEUTRON-TRANSMUTATION-DOPED SILICON. (Plenum, 1981).

Hamakawa, Y. (Ed.): AMORPHOUS SEMICONDUCTOR TECHNOLOGIES AND DEVICES. (Ohmsha, Tokyo/N. Holland, 1982). This is Vol. 2 of the JaPAN ANNUAL Reviews in ElecTRONICS, etc.; for Vol. 1 see Nishizawa.

Hannay, N. B. \& Colombo, U. (Eds.): EleCtroniC MATERIaLs. (Plenum, 1973). Conf. proc.

Hasiguti, R. R. (Ed.): DefECTS AND RADIATION EFFECTS IN SEMICONDUCTORS. (Inst. of Physics, London, 1981).

Heywang, H. \& Weiss, H. (Eds.): SOLID STATE DEVICES. (Inst. of Physics, London, 1971). Conf. proc.

Hilsum, C. (Ed.): Gallium arsenide and Related COMPOUNDS. (Inst. of Physics, London, 1973). Symp. proc.

Hilsum, C. (Ed.): HANDBOOK ON SEMICONDUCTORS, Vol. 4: Device PHysics. (N. Holland, 1980). For Vols. 1, 2 and 3, see Paul, Balkanski and Keller, respectively.

Hilsum, C. \& Eastman, L. F. (Eds.): Gallium arsenide AND RELATED COMPOUNDS. (Inst. of Physics, London, 1977). Symp. proc. (2 vols.).

Huntley, F. A. (Ed.): LATTICE DEFECTS IN SEMICONDUCTORS. (Inst. of Physics, London, 1975). Conf. proc.

Kaldis, E. (Ed.): CurRent topics IN MATERIALS SCIENCE, Vols. 1 (1978), 2 (1977), 3 (1979), 4, 5 and 6 (1980). (N. Holland). This review series deals with very varied topics, with emphasis on electronic materials. Reviews of Vols. 1, 2,3 and 4 in $\mathrm{J13}, 107 ; \mathbf{J 1 1}, 673 ; \mathrm{J13}, 636$; and $\mathrm{J13}, 637$; and of Vols. 5 and 6 in J15, 141 
Kaldis, E. \& Schieber, M. (Eds.): CRYSTAL GROWTH AND EPITAXY FROM THE VAPOUR PHASE. (N. Holland, 1971).

Kao, K. C. \& Hwang, W.: Electrical tRanSPORT IN SOlidS, WITH PARTICULAR REFERENCE TO ORGANIC SEMICONDUCTORS. (Pergamon, 1981). Review in A38, 174. See also Silinsh, in 2. Crysial Physics.

Kazmerski, L. L. (Ed.): POlyCRySTALline AND AMORPHOUS THIN FILMS AND DEVICES. (Academic Press, 1980).

Keller, S. P. (Ed.): HaNDBOOK ON SEMICONDUCTORS, Vol. 3 : MATERIALS AND THEIR PREPARATION. (N. Holland, 1980). For Vols. 1, 2 and 4, see Paul, Balkanski and Hilsum, respectively.

Kitagawa, T. (Ed.): COMPUTER SCIENCE AND TECHNOLOGIES 1982. (Ohmsha, Tokyo/N. Holland, 1982). See also Nishizawa, below.

Kressel, H. (Ed.): CharaCTERISATION OF EPITAXIAL SEMICONDUCTOR FILMS. (Elsevier, 1976). Review in J10, $21 \mathrm{l}$.

Lannoo, M. \& Bourgoin, J.: PoINT Defects in SEmiconducTORS. (Springer, 1981).

Levin, A. A.: QUaNTUM CHEMISTRY OF SOLIDS: THE CHEMICAL BOND AND ENERGY BANDS IN TETRAHEDRAL SEMICONDUCTORS. (McGraw-Hill, 1977). Review in A35, 508.

Lines, M. E. \& Glass, A. M.: Principles and applications OF FERROELECTRIC AND RELATED MATERIALS. (OUP, 1977).

Lovett, D. R.: SEMIMETALS AND NARROW BANDGAP SEMICONDUCTORS. (Academic Press, 1977).

Nag, B. R.: ElECTRON TRANSPORT IN COMPOUND SEMICONDUCTORS. (Springer, 1980).

Narayan, J. \& Tan, T. Y. (Eds.): DefECTS IN SEMICONDUCTORS. (N. Holland, 1981). Symp. proc.

Nishizawa, J. (Ed.): SEMICONDUCTOR TECHNOLOGIES 1982. (Ohmsha, Tokyo/N. Holland, 1982). This is the first Vol. of a series with the title JaPAN ANNuAl Reviews IN Electronics, Computers and Telecommunications. For Vols. 2, 3 and 4, see Hamakawa, Suematsu and Kitagawa.

Ormont, B. F.: EINFührung IN diE PHYSIKalische Chemie und KRistallchemie der Halbleiter. (Akademie-Verlag, 1979).

Pamplin, B. R. (Ed.): Molecular beam epitaxy. (Pergamon, 1980). Review in J14, 76.

Paul, W. (Ed.): HandbOOK ON SEMICONDUCTORS, Vol. 1: BAND THEORY AND TRANSPORT PROPERTIES. (N. Holland, 1982). For the other volumes of this series, see Balkanski, Hilsum, and Keller. The overall editor of this series is T.S. Moss.

Phillips, J. C.: Bonds AND BandS IN SEMICONDUCtors. (Ácademic Press, 1973).

Rauluszkiewicz, J. et al. (Eds.): PHYSICS OF NARROW-GAP SEMICONDUCTORS. (N. Holland, 1978). Proc. of Warsaw conf. of 1977.

Ravi, K. V.: IMPERFECTIONS AND IMPURITIES IN SEMICONDUCTOR SILICON. (Wiley, 1981).

Ridley, B. K.: QUANTUM PROCESSES IN SEMICONDUCTORS. (OUP, 1982).

Robson, P. N. (Ed.): Solid state Devices. (Inst. of Physics, London, 1973). Conf. proc.

Shay, J. L. \& Wernick, J. H.: Ternary Chalcopyrite SEMICONDUCTORS: GROWTH, ELECTRONIC PROPERTIES AND APPLICATIONS. (Pergamon, 1975).

Skobel'tsyn, D. V. (Ed.): Radiative Recombination IN SEMICONDUCTING CRYSTALS. (Plenum, 1975). Translated from Russian.
Street, R. A. et. al. (Eds.): TETRAHEDRALLY BONDED AMORPHOUS SEMICONDUCTORS. (American Inst. of Physics, 1981). Conf. proc

Suchet, J. P.: CRYSTAL Chemistry AND SEMICONDUCTION IN TRANSITION METAL BINARY COMPOUNDS. (Academic Press, 1971).

Suematsu, Y. (Ed.): OPTICAL DEVICES AND Fibres 1982. (Ohmsha, Tokyo/N. Holland, 1982). This is the third Vol. of the series entitled JAPAN AnNual Reviews etc.: see Nishizawa, above.

Sugano, T. (Ed.): Gallium arSenide and Related COMPOUNDS. (Inst. of Physics, London, 1982). Proc. of the 9th Int. Symp. on GaAs.

Sze, S.: Physics of SEMiconductor Devices, 2nd ed. (Wiley, 1981).

Szigeti, G. (Ed.): Physics And Chemistry of SEMiconducTOR HETEROJUNCTIONS AND LAYER STRUCTURES. (Akadémiai Kiadó Budapest, 1971). Conf. proc.

Thim, H. W. (Ed.): Galluum aRSENIDE and RELATEd COMPOUNDS. (Inst. of Physics, London, 1981). Symp. proc.

Thomas, L. A. (Ed.): Solid state Devices. (Inst. of Physics, London, 1975). Conf. proc.

Tomashpolsky, Yu. Ya. \& Platonov, G. L.: Ferroelectric FILMS OF METALLIC COMPLEX OXIDES. (in Russian). (Soviet Metallurgy, 1978). Review, in English, in J13, 636.

Vigdorovič, V. N.: PURIFICATION OF METALS AND SEMICONDUCTORS BY CRYSTAllisation. (Freund Publ. Co., Tel Aviv, 1971).

Wang, F. F. Y.: INTRODUCTION TO SOLID STATE ELECTRONICS. (N. Holland, 1979). Not particularly well thought of by the review: A37, 143.

Wang, F. F. Y. (Ed.): IMPURITY DOPING PROCESSES IN SILICON. (N. Holland, 1981).

Weiss, H. (Ed.): Solid STATE Devices. (Inst. of Physics, London, 1974). Conf. proc. (of München, 1973).

Weiss, H. (Ed.): SOlID STATE DEVICES. (Inst. of Physics, London, 1980). Conf. proc. (of München, 1979).

Whitehouse, J. E. (Ed.): RADIATION DAMAGE AND DEFECTS IN SEMICONDUCTORS. (Inst. of Physics, London, 1973). Conf. proc.

Wilcox, W. R.: PREPARATION AND PROPERTIES OF SOLID STATE MATERIALS. (Dekker, 1971).

Wilson, B. L. H. (Ed.): Physics of SEMiCONDUCtors. (Inst. of Physics, London, 1979). Conf. proc.

Wolfe, C. M. (Ed.): Gallium aRSENide AND RELATED COMPOUNDS. (Inst. of Physics, London, 1979). Symp. proc.

Yonezawa, F.: Fundamental PHYSICS OF AMOR PHOUS SEMICONDUCTORS. (Springer, 1981).

Zemel, J. N. (Ed.): Nondestructive evaluation of SEMICONDUCTOR MATERIALS AND DEVICES. (Plenum, 1979). Review in $\mathrm{J13}, 342$.

\section{Materials as Electrolytes/Fast Ionic Conductors}

Armstrong, R. D. (Ed.): SOLID IONIC AND IONIC-ELECTRONIC CONDUCTORs. (Pergamon, 1977). Review in A34, 832.

Chandra, S.: SUPERIONIC SOLIDS: PRINCIPLES AND APPLICATIONS. (N. Holland, 1981). Recommended as a good textbook for this new subject of solid electrolytes.

Geller, S. (Ed.): Solid ElECTROLyTES. (Springer, 1977). Review in A34, 640. 
Gool, W. van (Ed.): FAST ION TRANSPORT IN SOLIDS. (N Holland, 1972).

Mahan, G. D. \& Roth, W. (Eds.): Superionic CONDUCTORS. (Plenum, 1976). Conf. proc.

Salamon, M. B. (Ed.): Physics OF SUPERIONIC CONDUCTORS. (Springer, 1979). Review in A35, 1089.

Subbarao, E. C. (Ed.): Solid Electrolytes AND their APPliCATIONS. (Plenum, 1980).

Vashishta, P. D. et al. (Eds.): FAST ION TRANSPORT IN SOLIDS. (N. Holland, 1979). Papers presented in Wisconsin, 1979.

Note: A new journal, Solid State Ionics (N. Holland), started 1980

\section{Materials of Low Dimensionality}

Alcacer, L. (Ed.): THE PHYSICS AND CHEMISTRY OF LOW DIMENSIONAL SOLIDS. (Reidel, 1980). Summer school proc. The easy, but unfortunate phrases, 'low-dimensional' or '1-dimensional solids' refer to materials having exceptionally marked uni-directional properties (high anisotropic ratios), electronic conduction in particular.

Barišič, S. et. al. (Eds.): QUASI ONE-DIMENSIONAL CONDUCToRs. (Springer, 1979). Conf. proc.

Bernasconi, J. \& Schneider, T. (Eds.): Physics IN ONE DIMENSION. (Springer, 1981). Conf. proc.

Devreese, J. T. et al. (Eds.): Highly Conducting 1-DimenSIONAL SOLIDS. (Plenum, 1979).

Hatfield, W. E. (Ed.): Molecular metals. (Plenum, 1980).

Keller, H. J. (Ed.): ChEMISTRY AND PHYSiCS OF ONE-DIMENSIONAL METALS. (Plenum, 1977). Review in B34, 2068.

Keller, H. J. (Ed.): Low-DimENSIONAL COOPERATIVE PHENOMENA. (Plenum, 1975). Review in A32, 749.

Miller, J. S. (Ed.): EXTENDED LINEAR CHAIN COMPOUNDS, Vols. 1 and 2. (Plenum, 1982).

Miller, J.S. \& Epstein, A. J. (Eds.): SyNTHESIS AND PROPERTIES OF LOW DIMENSIONAL MATERIALS. (New York Academy of Sciences, 1978). This voluminous collection of the proceedings of a 1978 conference gives the best current picture of this fast-developing subject. Review in B35, 1746.

\section{Mathematics/Computing}

Ahmed, F. R. (Ed.): Crystallographic computing: ProCEEDINGS OF THE 1969 SUMMER SCHOOL, OTTAWA (Munksgaard, 1970). Review in A27, 191.

Ahmed, F. R. (Ed.): Crystallographic COMPuting techNIQUES: PROCEEDINGS OF THE 1975 SUMMER SCHOOL, Prague. (Munksgaard, 1976). Review in A34, 350.

Diamond, R., Ramaseshan, S. \& Venkatesan, K. (Eds.): Computing in CRystallography: Proceedings of THE 1980 WINTER SCHOOL, BANGALORE. (Indian Academy of Sciences, 1980). Review in A37, 446.

Herman, F. et al. (Eds.): Computational solid STATE PHysics. (Plenum, 1972). Conf. proc.

Kuntsevič, I. M. et al.: TABLES OF TRIGONOMETRIC FUNCTIONS FOR THE NUMERICAL COMPUTATION OF ELECTRON DENSITY IN CRYSTALS. (Israel Program for Scientific Translations, 1971).

Nowacki, W.: BIbliography OF Mathematical CRYSTalloGRAPHY (to 1980, approx). For details of this, and the availability of copies from the IUCr, see A38, 558 or $\mathrm{J15}$, 470.
Prince, E.: Mathematical techniques in CRystallogRAPHY AND MATERIALS SCIENCE. (Springer, 1982). A very helpful and comprehensive guide.

Ramachandran, G. N. \& Srinivasan, R.: FOURIER METHODS IN CRYSTALLOGRAPHY. (Wiley, 1970). Review in A27, 506.

Sands, D. E.: VECTORS AND TENSORS IN CRYSTALLOGRAPHY. (Addison Wesley, 1982).

Schenk, H. et al. (Eds.): COMPUTING IN CRYSTALlOGRAPHY: Proceedings OF THE 1978 SUMMER SCHOOL, THE NETHERLANDS. (Delft Univ. Press, 1978).

Srinivasan, R. \& Parthasarathy, S.: SOME STATISTICAL APPLICATIONS IN X-RAY CRYSTAllogRaPHY. (Pergamon, 1976). Available also in Russian translation (MIR, 1979).

Wooster, W. A.: TENSORS AND GROUP THEORY FOR THE PHYSICAL PROPERTIES OF CRYSTALS. (OUP, 1973).

Also note: Hamilton, W. C.: STATISTICS IN PHYSICAL SCIENCE. (Ronald Press, 1964). 'An outstanding book'.

\section{Methods for Solving Structures}

Galdecki, Z. (Ed.): X-Ray Structure analysis. (in Polish) (Ossolineum, Warsaw, 1974). Summer school lectures.

Giacovazzo, C.: DiRECT METHODS IN CRYSTALlOGRAPHY. (Academic Press, 1980). Review in B37, 1801.

Hauptman, H. A.: Crystal structure determination. (Plenum, 1972). Review in A29, 486.

Hauptman, H. A. (Ed.): DiReCT METHODS IN CRYSTAllograPHY. (Polycrystal Book Service, 1978). Proc. 1976 symp., Buffalo. Review in A35, 701.

Hoppe, W. \& Mason, R. (Eds.): UnCONVENTIONAL Electron MICROSCOPY FOR MOLECULAR STRUCTURE DETERMINATION. (Vieweg, 1979). Review in B36, 2509.

Kuz'min, E. A. et al:: Systematic analysis of Patterson FunCTIONS. (in Russian). (Nauka, 1974). Review, in Russian, in A34, 479.

Ladd, M. F. C. \& Palmer, R. A.: Structure determination BY X-RAY CRYSTALlogRaPhy. (Plenum, 1977). Review in B34, 1400.

Ladd, M. F. C. \& Palmer, R. A. (Eds.): ThEORY AND PRACTICE OF DIRECT METHODS IN CRYSTALLOGRAPHY. (Plenum, 1980). Review in B36, 2860.

Lipson, H. (Ed.): Optical. Transforms. (Academic Press, 1972). Ch. 3 refers particularly to structure solution by use of optical transforms.

Rossmann, M. G.: THE MOLECULAR REPLACEMENT METHOD. (Gordon \& Breach, 1972). This method is for very large, multi-component structures.

Stout, G. H. \& Jensen, L. H.: X-RAy STRuCture deTerminaTION: A PRACTICAL GUIDE. (Macmillan, 1972). Although written in 1968 , this text is still very popular: this is its 5 th printing.

\section{Minerals}

Arkhipenko, D. K. (Ed.): SPECTROSCOPY AND X-RAY INVESTIGATION OF MINERALS. (in Russian). (Nauka, Novosibirsk, 1971).

Aubert, G. et al:: Précis de minéralogie. (Masson, 1978).

Bancroft, P.: THE WORLD'S FINEST MINERALS AND CRYSTALS. (Viking Press, NY, 1973).

Bank, H.: Aus der Welt der Edelsteine. (Pinguin Verlag, Innsbruck, 1973). 
Bariand, P. et al:: Les miNÉraux. (Minéraux et Fossiles, Meung-sur-Loire, 1977).

Battey, M. H.: Mineralogy For students. (Oliver \& Boyd, 1975).

Bolewski, A. et al.: General mineralogy. (in Polish) (Wydawnictwo Geologiczne, Warsaw, 1975).

Bonatti, S. \& Franzini, M.: Cristallografia miNeralogica. (Boringhieri, Torino, 1972).

Brauns, R. \& Chudoba, K. F.: Spezielle Mineralogie. (de Gruyter, 1979).

Brindley, G. W. \& Brown, G. (Eds.): Crystal structures or CLAY MINERALS AND THEIR X-RAY IDENTIFICATION. (Mineralogical Society, London, 1980). This large and comprehensive volume is the latest updated version of the book first published in 1951, with its 2 nd ed. in 1961. Review in B37, 1481.

Burns, R. G.: Mineralogical applications of Crystal FIELD THEORY. (CUP, 1970). Review in J3, 287.

Cox, K. G. et al:: CRYstals, minerals and rocks. (McGraw-Hill, 1974).

Deer, W. A., Howie, R. A. \& Zussman, J.: Rock-FoRming MINERALS. (Longman, 1972).

Dreyer, W.: MATERIALVERHALTEN ANISOTROPER FESTKÖRPER: THERMISCHE UND ELEKTRISCHE EIGENSCHAFTEN: EIN BEITRAG ZUR ANGEWANDTEN Mineralogie. (Springer, 1974).

Eberhart, J.-P.: MÉTHODES PHYSIQUES D'ÉTUDE DFS MINÉRAUX ET DES MATÉRIAUX SOLIDES. (Doin, 1976). Review in A33, 861 .

Font Altaba, M.: Atlas de mineralogía. (Ed Jover, Barcelona, 1971).

Frank-Kamenetskij, V. A. (Ed.): HANDBOOK FOR THE INVESTIGATION OF MINERALS. (in Russian). (Nedra, 1975). This is a handbook for the examination of minerals and industrial materials; it excludes structural analysis. Review, in English, in J9, 514.

Gait, R. I. \& Williams, A.: Exploring minerals AND CRYSTALS. (McGraw-Hill, 1972).

Gard, J. A.: The electron-optical investigation of CLAYS. (Mineralogical Society, London, 1971).

Gramaccioli, C. M.: Die Mineralien der AlPeN, Band 1-2. (Ott Verlag, Thun, 1978).

Gübelin, E. J.: INNENWELT DER EdelsteINe. (ABC Verlag, Zürich, 1973).

Hintze, C. \& Chudoba, K. F.: Handbuch der Mineralogil: Ergänzungsband IV: NeuE Mineralien UND MineralNAMEN, Lieferungen 1 und 2. (de Gruyter, 1974, 1975).

Hinz, W.: Silikate. (Verlag f. Bauwesen, Berlin, 1970).

Kalokerinos, A.: AUSTRalian precious OPAl. (Arco, New York, 1972).

Komov, I. L.: Radiation mineralogy, 3rd ed. (in Russian). (Moscow Energy Publ., 1982).

Ladurner, J. \& Purtscheller, F.: Das grosse MineralienBUCH. (Pinguin Verlag, Innsbruck, 1970).

Liebau, F.: Fortschritte auf dem Gebiet der KristallCHEMIE DER SiliKATE. (Westdeutscher Verlag, 1978).

Lippmann, F.: Sedimentary Carbonate minerals. (Springer, 1973).

McConnell, D.: APATITE: ITS CRYSTAL CHEMISTRY, MINERALOGY, UTILISATION AND GEOLOGIC AND BIOLOGIC OCCURRENCES. (Springer, 1973). Review in B37, 780.

MacKenzie, W. S.: THE FeldSPARS. (Manchester Univ. Press, 1974).
Marfunin, A. S.: Physics OF MINERALS AND INORGaniC MATERIALS: AN INTRODUCTION. (Springer, 1979).

Marfunin, A. S.: SPECTROSCOPY, LUMINESCENCE AND RADIATION CENTRES IN MINERALS. (Springer, 1979). Translated from Russian. Review in A36, 500.

Meier, W. M. \& Olson, D. H.: Atlas of Zeolite structure TYPES. (Distributed by Polycrystal, 1978). This booklet depicts 38 selected zeolite structures in good stereopictures, fully backed by explanatory notes and bibliography.

Mortier, W. J.: COMPILATION OF EXTRA FRAMFWORK SITES IN ZEOLITES. (Butterworth, 1982). See also Meier just above.

Nicholas, A.: CRystalline Plasticity AND SOlid STATE FLOW IN METAMORPHIC ROCKS. (Wiley, 1976).

Nickel, E.: Grundwissen in Minfralogie, Teilen 1, 2 und 3. (Ott Verlag, Thun, 1971, 1973, 1975).

Parker, R. L.: Mineralienkunde, 5. Aufl. (Ott Verlag, Thun, 1975).

Phillips, W. R. \& Griffen, D. T.: Optical mineralogy: the NONOPAQUE MINERALS. (Freeman, 1981).

Picot, P. \& Johan, Z.: ATlas Des mint́rauX METAlliques. (Mémoires du Bureau de recherches géologiques et minières, Paris, 1977).

Plyusnina, I. I.: The INFrared spectra OF Minerals. (Moscow Univ. Press, 1981).

Povarennykh, A. S.: Crystal Chemical Classification of MINERALS. (Plenum, 1972). Translation from Russian.

Ramdohr, P.: Die ERzMineralien UND IHRE VerwachsunGEN. (Akademie-Verlag, 1975).

Ramdohr, P. \& Strunz, H.: KlockmanNs LeHRBuch DER Mineralogie, 16 Aufl. (Ferdinand Enke Verlag, Stuttgart, $1978)$.

Ransom, J. E.: Gems and minerals of AmERICA. (Harper \& Row, 1974).

Roberts, W. L. el al: ENCYCLOPEDIA OF MINERALS. (Van Nostrand, 1974)

Rösler, H.-J.: Lehrbuch der Mineralogie, 2. Aufl. (VEB Leipzig, 1981).

Rösler, H.-J.: LeHRBUCH DER SPEZIFllen Mineralogie. (Deutsche Verlag f. Grundstoffindustrie, 1979).

Rykart, R.: BERGKRISTALl: FORM UND SCHÖNHEIT ALPINER Quarze. (Ott Verlag, Thun, 1971).

Saggerson, E. P.: IDENTIFTCATION TABles For Minerals in THIN SECTIONS. (Longman, 1975).

Sand, L. B. (Ed.): Natural zeolites. (Pergamon, 1976). Conf. proc.

Sand, L. B. \& Mumpton, F. A. (Eds.): Natural zeolites: ocCurrence, properties, uSe. (Pergamon, 1976). Conf. proc.

Schröcke, H. \& Weiner, K.-L.: Mineralogie. (de Gruyter, 1981).

Seim, R.: Minerale. (Neumann-Verlag, Radebeul, 1970).

Shafranovskii, I. I.: ESSAYS ON MINERALOGICAL CRYSTALLOGRAPHY. (in Russian). (Nedra, 1974).

Shelley, D.: Manual OF OPTICAL mineralogy. (Elsevier, 1975). Review in A33, 348.

Smith, J. V.: FeldSPAR Minerals, Vols. 1 and 2. (Springer, 1974).

Strens, R. G. J. (Ed.): ThE PHYSICS AND CHEMISTRY OF MINERALS AND ROCKS. (Wiley, 1976). NATO inst. proc.

Strübel, G.: Mineralogie. (Ferdinand Enke Verlag, Stutt- 
gart, 1977). A good paperback on mineralogical crystallography (in German).

Strübel, G.: Mineralogie Und Kristallographie, 3. Aufl. (Verlag Studiengemeinschaft, Darmstadt, 1973).

Strunz, H.: Mineralogische TABellen, 7. Aufl. (AkademieVerlag, 1978).

Takeuchi, Y.: GeOChEMISTRY AND CRYSTAllography of SULPHIDE MINERALS IN HYDROTHERMAL DEPOSITS. (Society of Mining Geologists of Japan, 1971).

Townsend, R. P.: The Properties AND appliCations OF ZEOLITES. (The Chemical Society, London, 1980).

Tröger, W. E.: (Edited by Bambauer, H. U. et al.): OPTICAL DETERMINATION OF ROCK FORMING MINERALS, Part 1. DETERMINATIVE TABLES. (E. Schweizerbart'sche Verlagsbuchhandlung, Stuttgart, 1979). Teil 2 (TextBand) of this treatise, dated 1967, is available in German from the same publisher.

Vinokurov, V. M. (Ed.): COMPOSITION, STRUCTURE AND PROPERTIES OF MINERALS: CRYSTALLOGRAPHIC INVESTIGATION. (in Russian). (Kazań, 1973).

Weibel, M.: Die Mineralien der Schweiz, 4. Aufl. (Birkhäuser Verlag, Basel, 1972).

Wenk, H. R. (Ed.): Electron Microscopy in MiNERAlOGY. (Springer, 1976)

Note: A new journal, ZEOLITES: AN INTERNATIONAL JOURNAL OF Molecular Sieves, started 1981 (IPC Science \& Technology, Guildford, GU2 5BH, England).

\section{Miscellaneous}

Alper, A. M. (Ed.): High temperature oxides. (Academic Press, 1970).

Amorós, J. L. et al.: The Laue method. (Academic Press, 1975).

Arem, J. E.: MaN-MADE CRYSTals. (Smithsonian Inst. Press, 1973).

Arsen'ev, P. A.: KRISTALle IN DER MODERNEN LASERTECHNIK. (Akademische Verlag Geest \& Portig, Leipzig, 1980). See also Kaminskii, and Pellegrini, below.

Association of University Radiation Protection Officers (UK): A GUIDE TO THE SAFE USE OF X-RAY CRYSTALLOGRAPHIC AND SPECTROMETRIC EQUIPMENT. (1978). (Obtainable from P. J. F. Griffiths, UWIST, Cardiff, England). See also Moore, below.

Backhaus, K.-O.: KristallograPHIE: EIN TECHNIK-WORTERBUCK. (VEB Verlag, 1972). This is a small, specialised dictionary of $\sim 130$ pages, giving the English, German, French and Russian equivalent for $\sim 3600$ technical terms in the areas relevant to crystallography. (It is obtainable from Buchexport, Leipzig, Leninstr. 16, DDR-7010).

Balaban, M. (Ed.): SCIENTIFIC INFORMATION TRANSFER. (Reidel, 1978). Review in A35, 1090. This is essentially for book editors and librarians.

Barnes, A. J. et al. (Eds.): MATRIX ISOlATION SPECTROSCOPY. (Reidel, 1981). Lectures given at the NATO inst. of 1980.

Barrow, R. F. et al. (Eds.): MoleCULAR SPECTROSCOPY, Vol. 5. (The Chemical Society, London, 1978!. Two articles in this Vol. are of interest to crystallographers. Review in A35, 702.

Behrisch, R. (Ed.): SPUTTERING BY PARTICLE BOMBARDMENT, Vol. 1. (Springer, 1981). Review in A38, 399.

Bhide, V. G.: Mössbauter EFFECT AND ITS APPLICATIONS.
(Tata McGraw-Hill, New Delhi, 1973). See also Gonser, Gruverman, Stevens, and Vértes, below.

Blinc, R. \& Žekš, B.: SOFT MODES IN FERROELECTRICS AND ANTIFERROELECTRICS. (N. Holland, 1975). For several other titles in this area, see Conolly, below.

Bobeck, A. H. \& Della Torre, E.: Magnetic BubBles. (N. Holland, 1975). See also Eschenfelder, Lachowitz, and O'Dell, below.

Bojarski, Z. et al.: Dictionary OF CRYSTALLOGRAPHIC TERMS in Polish, English and Russian. (PWN, Warsaw, 1970).

Bond, W. L.: Crystal technology. (Wiley, 1976). A book for the crystal-handling workshop. Review in J11, 293. Also available in Russian translation (Nedra, 1980).

Burfoot, J. C. \& Taylor, G. W.: POlar DieleCtrics AND THEIR APPLICATIONS. (Univ. of California, 1979).

Cairns-Smith, A. G.: THE LIFE-PUZZLE: ON CRYSTALS AND ORGANISMS, AND ON THE POSSIBILITY OF A CRYSTAL AS AN ANCESTOR. (Oliver \& Boyd, 1971).

Casasent, D. (Ed.): OPTICAL DATA PROCESSING. (Springer, 1978). Review in A35, 253.

Chadwick, G. A. \& Smith, D. A.: Grain boundary struCTURE AND PROPERTIES. (Academic Press, 1976).

Chaudhari, P. \& Matthews, J. W.: Grain boundaries AND INTERFACES. (N. Holland, 1972). Review in J6, 422.

Chesney, D. N. \& Chesney, M. O.: X-RAY EQUIPMENT FOR STUDENT RADIOGRaPHERS, 2nd ed. (Blackwell, 1975).

Conolly, T. F.: Ferroelectrics Litera TURE index. (Plenum, 1974).

Conolly, T. F. \& Turner, E.: Ferroelectric materials and FERroelectricitY. (Plenum, 1970). See also Conolly, just above; and see Lefkowitz, and Mitsui, below.

Coulomb, P.: Les Textures dans les MÉTEAUX DE RÉSEAU Cubique. (Dunod, 1972). Review, in English, in J6, 422.

Elwell, D.: Man-made Gemstones. (Horwood, 1979). Review in A36, 334. For two other recent books on gemology, see Hurlburt and Nassau; Nassau, addressed to the scientist rather than to the layman, is particularly good value. See also Read and Smith, below.

EngIman, R.: NON-RADIATIVE DECAY OF IONS AND MOLECULES IN SOLIDS. (N. Holland, 1975). Review in A36, 1090.

Eschenfelder, A. H. (Ed.): MAGNETIC BUBBLE TECHNOLOGY, 2nd ed. (Springer, 1981). See also Bobeck, Lachowitz, and O'Dell.

Evans, C. C.: Whiskers. (Mills \& Boon, London, 1972).

Field, J. E. (Ed.): THE PROPERTIES OF DIAMOND. (Academic Press, 1978).

Fonash, S. J.: Solar cell device Physics. (Academic Press, 1981). See also Coutts in 12. Materials.

Furrer, A. (Ed.): CRYSTAL FIELD EFFECTS IN METALS AND ALLOYS. (Plenum, 1977). Conf. proc.

Gamarnik, M. J.: ANALYTICAL METHOD OF ADJUSTMENT OF A GONIOMETER OF AN X-RAY DIFFRACTOMETER. (in Russian). (Kiev, 1976).

Garrido, J.: Forma y estructura de los CRISTALES. (Ed Alhambra, Madrid, 1973).

Ginzburg, V. L. \& Kirzhnits, D. A. (Eds.): HıGH-TEMPERATURE SUPERCONDUCTIVITY. (Plenum, 1981). Translation from Russian. See also Shenoy, Vonsovsky, Weber, and White, below.

Glatter, O. \& Kratky, O. (Eds.): Small angle X-Ray SCATTERING. (Academic Press, 1982). 
Gonser, U. (Ed.): MössbaUer SPECTROSCOPY, Vols. I and II. (Springer, 1975 and 1981). Review of Vol. I in J9, 259; Vol. II in A38, 174. See also Gruverman, Stevens, and Vértes, below.

Götz, J. (Ed.): Glass, 1977, Vol. 1: Glass SCIENCE and Vol. 2: TECHNOLOGY AND USES OF GLASSES. (N. Holland, 1977). Review in J12, 428.

Gruverman, I. J. \& Seidel, C. W. (Eds.): Mössbaufr EFFECT METHOdOlOGY, Vol. 10. (Plenum, 1976). Review in A33, 861. See also Gonser, Stevens, and Vértes.

Gschneider, K. A. \& Eyring, L. (Eds.): HANDBOOK ON THE PHYSICS AND CHEMISTRY OF RARE EARTIS, Vols. 1, 2, 3 and 4. (N. Holland, 1979). Reviews in A35, 1089; B36, 2512 and 2861 . Very comprehensive, on all aspects of the rare earths. See also McCarthy, below.

Guntherodt, H. J. \& Beck, H. (Eds.): Glassy metals, I. (Springer, 1981).

Health \& Safety Executive, Advisory Committee (UK): Asbestos. (HMSO, London, 1979). Review in J14, 77.

Hoppe, W. \& Mason, R. (Eds.): Advances in structural RESEARCH BY DIFFRACTION METHODS, Vol. 3. (Vieweg, 1970). This issue contains an article by Hosemann, R. et al. On SMALL-ANGLE SCATTERING.

Hurlburt, C. S. \& Switzer, G. S.: Gemology. (Wiley, 1979). Review in A35, 1090. See also Elwell, Nassau, and Smith.

Jain, S. C. \& Chadderton, L. T.: NonmetalliC CRYSTals. (Gordon \& Breach, 1970).

Kaminskii, A. A.: L.ASER CRYSTALS. (Springer, 1981). This is the English translation of the original Russian version of 1975, now also updated and enlarged. Review in J14, 355. See also Arsen'ev, and Pellegrini.

Kubiak, R.: ACCURACY AND PRECISION OF MEASUREMENTS IN X-Ray structure analysis. (in Polish). (PWN, Warsaw, 1978). Papers of the Crystallographic Committee of the Polish Academy of Science.

Kunz, C. (Ed.): Synchroton Radiation. (Springer, 1979). Comment in A36, 333. See also Teo and Winick, below.

Lachowitz, H. (Ed.): Magnetic BubBles. (Polish Scientific Publ., Warsaw, 1976). Winter school proc. See also Bobeck, Eschenfelder, and O'Dell.

Lang, S. B.: SOURCEBOOK OF PYROELECTRICITY. (Gordon \& Breach, 1974).

Lazarenko, E. K. \& Vynar, O. N.: MineralogiCal dictioNARY: UKRANIAN-RUSSIAN-ENGLISH. (Naukova Dumka, 1975).

Lefkowitz, I. \& Taylor, G. (Eds.): Low-FlyING LATTICE VIBRATION MODES AND THEIR RELATIONSHIP TO SUPERCONDUCTIVITY AND FERROELECTRICITY, Vols. 1 and 2. (Gordon \& Breach, 1977). Conf. proc. There are also, by the same authors and publishers, further volumes of proceedings of later conferences on ferroelectricity.

Leteurtre, J. \& Quéré, V.: IRRADIATION EFFECTS IN FISSILE MATERIALS. (N. Holland, 1972).

Lipson, H. (Ed.): OptiCAL TRANSForms. (Academic Press, 1972). See also Harburn, listed under 26. Student-Oriented Texts/Books for Students.

McCarthy, G. J. et al. (Eds.): THE RARE EARTHS IN MODERN SOCIETY AND TECHNOLOGY, Vols. 1 and 2. (Plenum, 1980). Conf. proc. Review of Vol. 2 in B38, 1685. See also Gschneider, above.

McConnell, D.: APATITE: ITS CRYSTAL CHEMISTRY, MINERALOGY, UTILISATION AND GEOLOGIC AND BIOLOGIC OCCUR-
RENCES. (Springer, 1973). Review in B37, 780.

Marfunin, A. S.: SPECTROSCOPY, LUMINESCENCE AND RADIATION CENTRES IN MINERALS. (Springer, 1979). Review in A36, 500 .

Mirkin, L. I.: X-RAY STRUCTURE ANALYSIS: A PRACTICAL GUIDE FOR OBTAINING X-RAY PATTERNS AND MAKING MEASUREMENTS FROM THEM. (in Russian). (Nauka, 1976).

Mitsui, T. et al:: AN INTRODUCTION TO THE PHYSICS OF FERROELECTRICS. (Gordon \& Breach, 1976). See also Conolly and Lefkowitz, above.

Moore, T. M.: Radiation SAFETy in X-RAY diffraction AND SPECTROSCOPY. (US Dept of Health, Education \& Welfare, Rockville, MD, 1971). See also, above, under Association of ....

Murphy, W. F. (Ed.): Proceedings of the VIITH INTERNATIONAL CONFERENCE ON RAMAN SPECTROSCOPY. ( $N$. Holland, 1980) Review in A38, 398.

Nassau, K.: Gems made BY MaN. (Chilton Book Co., Radnor, PA, 19089, USA, 1980). An excellent book. Review in B37, 493. See also Elwell, above.

Nemoshkalenko, V. V. \& Aleshin, V. G.: EleCtron SPECTROSCOPY OF CRYSTALS. (Plenum, 1979).

O'Dell, T. H.: Ferromagnetodynamics: MagnetiC BUbBLES, DOMAINS AND DOMAIN WALl.s. (Wiley, 1981). See also Bobeck, Eschenfelder, and Lachowitz.

Parsons, D. F.: Ultrasoft X-RAY MiCROSCOPY: ITS APPliCaTION TO BIOLOGICAL AND PHYSICAL SCIENCES. (NY ACademy of Sciences, 1980).

Pearce, P. \& Pearce, S.: Polyhedra Primer. (Van Nostrand, 1978). Diagrams and instructions on building models.

Pellegrini, C. (Ed.): Developments IN HIGH-POWER LASERS AND their APPlicatiois. (N. Holland, 1981). Proc. of the 'Enrico Fermi' course of 1978. See also Arsen'ev, and Kaminskii, above.

Pistorius, C. W. F. T.: Phase relationships and strucTURES AT HIGH PRESSURes. (Pergamon, 1976). Review in A32, 1038. See also Timmerhaus, below.

Poulet, H. \& Mathieu, J. P.: Vibration spectra AND SYMMETRY OF CRYSTALS. (Gordon \& Breach, 1976).

Preuss, E.: LaUe atlas. (Wiley, 1974).

Randolph, A. D.: DESIGN, CONTROL AND ANALYSIS OF CRYSTALLIZATION PROCESSES. (American Inst. of Engineers, NY 10017, USA, 1980).

Randolph, A. D. \& Larson, M. A.: TheOry OF PARTICUlate PROCESSES: ANALYSIS AND TECHNIQUES OF CONTINUOUS CRYSTAllisation. (Academic Press, 1971).

Read, P. G.: Gemological InStruments: their USE AND PRINCIPLES OF OPERATION. (Newnes-Butterworth, 1978).

Reynolds, C. \& Collins, T. C.: Excitons: THEIR PROPERTIES AND THEIR USES. (Academic Press, 1981).

Rudman, R.: LOW TEMPERATURE X-RAY DIFFRACTION. (Plenum, 1976). Review in B33, 3623.

Schneer, C. J. (Ed.): Crystal Form AND STRUCTURE (BenchMARK PAPERS IN GEOLOGY, No. 34). (Wiley, 1977). Review in A34, 349.

Schubert, K.: Crystal structures OF TWO-COMPONENT PHASES. (Russian translation from German) (Metallurgija, Moscow, 1971).

Shenoy, G. K. et al:: Ternary SUPERCONDUCtORS. (N. Holland, 1981). Conf. proc. See also Ginzburg, Vonsovsky, Weber, and White.

Sherwood, J. N. (Ed.): ThE PLASTICALly CRySTALline STATE. 
(Wiley, 1979). See also Poirier, in 2. Crystal Physics, and Gray \& Winsor, in 10. Liquid Crystals.

Smith, G. F. H.: Gemstones. (Chapman \& Hall, 1972). Review in J6, 501. See Elwell, and others, above.

Stevens, J. G. \& Shenoy, G. K. (Eds.): Mössbauer SPECtroSCOPY AND ITS CHEMICAL APPLICATIONS. (American Chemical Society, 1981). See also Bhide, Gonser, Gruverman, and Vértes.

Symons, M. C. R. (Ed.): Annual Reports of ThE Royal Society of Chemistry, Vol. 76, 1979, section C. (Royal Society of Chemistry, London, 1980). Ch. 7 in this report is an account by Neilson, G. W. \& Enderby, J. E. of the application of X-ray and neutron diffraction to aqueous solutions of electrolytes.

Taylor, C. A.: ImaGes. (Wykeham, 1978). Comment in A35, 254. A well-illustrated 'popular' book.

Teo, B. K. \& Joy, D. C. (Eds.): EXAFS spectroscopy: TECHNIQUES AND APPLICATIONS. (Plenum, 1981). On synchrotron radiation in general, see Kunz and Winick.

Timmerhaus, K. D. \& Barber, M. S. (Eds.): High Pressure SCIENCE AND TECHNOLOGY. (Plenum, 1979). Review in J12, 641. See also Pistorius, above.

Ubbelohde, A. R.: The MOLTEN STATE of MATter. (Wiley, 1978). Review in B35, 2828.

Vavrinecz, G.: ATLAS OF SUGAR CRYSTALS; DESCRIPTIVE MORPHOLOGY OF SUCROSE. (Verlag Dr Albert Bartens, Berlin, 1965). A delightful book.

Vértes, A. et al:: Mössbauer spectroscopy. (N. Holland, 1979). See also Bhide, Gonser, Gruverman, and Stevens, above.

Vogel, W.: Struktur und Kristallisation von Glassern. (VEB Deutscher Verlag f. Grundstoffindustrie, 1971). See also Götz, above, and Eitel, in 11. Materials and their Properties/Genera! Materials Science.

Vonsovsky, S. V. et al: SUPERCONDUCTIVITY OF TRANSITION METALS, THEIR ALLOYS AND COMPOUNDS. (Springer, 1982). Translation from Russian. See also Ginzburg, Shenoy, Weber, and White.

Wagner, R.: FiELd-ION MiCrosCopy in MATERIALS SCIENCE. (Springer, 1982). This is Vol. 6 of the series CRYSTALS, GrowTH, PROPERTIES AND APPLICATIONS, edited by Freyhardt; the other Vols. are listed under his name in Sections 1,11 and 12 .

Walton, A.: Molecular and Crystal structure models. (Horwood, 1978). Even a good survey of this subject dates rapidly.

Weber, H. W. \& Hittmair, O.: Supraleitung. (Karl Thiemig, 1979). Review, in English, in A36, 502. See also Ginzburg, Shenoy, Vonsovsky, and White.

White, R. M. \& Geballe, T. H.: LONG RANGE ORDER IN solids. (Academic Press, 1979). Broadly on superconductivity and magnetic phenomena.

Winick, H. \& Doniach, S.: SynChrotron Radiation RESEARCH. (Plenum, 1980). Comment in A37, 448. See also Kunz, and Teo, above.

Yen, W. M. \& Selzer, P. M. (Eds.): LASER SPECTROSCOPY OF Solids. (Springer, 1981). Review in A38, 175.

\section{Molecular Structures}

Allen, G. (Ed.): MOlecular STRuCture AND PROPERTIES. (Butterworth, 1972). This is Vol. 2 of the 'Series 1' of the
INTERNATIONAL REVIEW OF SCIENCE; it contains articles on neutron and electron diffraction as well as many articles on non-diffraction-based physical methods. The later book, corresponding to this, in 'Series 2', is edited by Buckingham: see below.

Brand, J. C. D., Speakman, J. C. \& Tyler, J. K.: MoleCulaR STRUCTURE, THE PHYSICAL APPROACH. (Arnold, 1975). This is the 2 nd, revised, ed. of the book originally by Brand \& Speakman. Review in B33, 317.

Buckingham, A. D. (Ed.): MOLECULhR STRUCTURE AND PROPERTIES. (Butterworth, 1975). This is Vol. 2 of the 'Series 2' of the InTERnational Review of SCIENCE; for the earlier 'Series 1' book, see Allen, above. This Vol. contains articles almost entirely devoted to non-diffraction-based methods. Crystal diffraction methods and their results are covered in Vol. 11 of this series, which is edited by Robertson: see below.

Bullen, G. J. \& Greenslade, D. J. (Eds.): Problems IN MOLECUlar STRUCTURES. (Chapman \& Hall, 1982). This surveys a very wide range of different methods for the determination of structures.

Clarke, M. J. el al. (Eds.): STRuCture AND BOnding. (Springer). This is less of a book than a journal: it is issued 'at irregular intervals, according to the material received'. Currently, there are 4 or 5 Vols. each year. There is a panel of editors. Only some articles are of direct crystallographic interest; one relevant to molecular structures is on crystallography of transition metal hydrides, in Vol. 44 (1980). Review of Vol. 44 in B38, 1684.

Cyvin, S. J.: Molecular Structures and vibrations. (Elsevier, 1972).

Dobler, M.: IONOPHORES AND THEIR STRUCTURES. (Wiley, 1981). In the context of molecular structures (as opposed to solution theory), ionophores are defined as molecules which are able to transport ions from an aqueous phase to a hydrophobic one. This is a presentation of all the structural information, especially $\mathrm{X}$-ray results, available on these compounds. Review in B38, 2097.

Dodson, G., Glusker, J. P. \& Sayre, D. (Eds.): STructural. STUDIES ON MOLECULES OF BIOLOGICAL INTEREST: A VOLUME IN HONOUR OF DOROTHY HODGKIN. (OUP, 1981).

Duax, W. L. \& Norton, D. A. (Eds.): Atlas of STERoID structure, Vol. 1. (Plenum, 1975). Review in B33, 3273.

Dunitz, J. D.: X-Ray analysis and THE structure of ORGANIC MOLeCules. (Cornell Univ. Press, 1979). This book, which should be of great interest to the organic chemist, is the sequel to J. M. Robertson's classic, ORganic CRystals and molecules (Cornell Univ. Press, 1953, but still in print). Review in B37, 493.

Dunitz, J. D. \& Ibers, J. A. (Eds.): Perspectives IN STRUCTURAL CHEMISTRY, Vol. 3. (Wiley, 1971). Review in B27, 1481 .

Gimarc, B. M:: Molecular Structure AND BONDING. (Academic Press, 1979). Review in B35, 2477.

Hirshfeld, F. L. (Ed.): ElECTRON DENSITY MAPPING IN MOLECULES AND CRYSTALS. (Weizmann Scientific Press, Israel, 1977). Review in A35, 254.

Hoppe, W. \& Mason, R. (Eds.): Advances in STRuCtural RESEARCH BY DIFFRACTION METHODS, Vol. 6. (Pergamon, 1975). Review in A33, 254. (See also Vol. 7 of this series, listed just below).

Hoppe, W. \& Mason, R. (Eds.): UnConventional electron 
MICROSCOPY FOR MOLECULAR STRUCTURE DETERMINATION. (Vieweg, 1979). Review in B36, 2509. This is Vol. 7 of the series On ADVANCES IN STRUCTURAL RFSEARCH BY DIFFRACTION METHODS; for Vol, 6, see above.

Kennard, O., Allen, F. H. \& Watson, D. G.: Molecular STRUCTURES AND DIMENSIONS: GUIDE TO THE LITERATURE, 1935-1976. (Bohn et al., Utrecht, 1977). Obtainable now from Reidel, Dordrecht, The Netherlands, or from Polycrystal Book Service, Chicago, USA. This large book, which gives the literature references for 40 years worth of crystal structures in one set of multiple indexes, is a companion volume to the series referred to just below and entered with more detail in 29. Tabulations/Data/Bibliography. Review in B34, 3847.

Kennard, O., Watson, D. G. et al. (Eds.): Molecular STRUCTURES AND DIMENSIONS, Vols. 1-12 (1969-1981) and Vol. 1A (1973). (Reidel) For further details on this remarkable compendium of molecular structures, see the entry in 29. Tahulations/Data/Bibliography.

Klyne, W. \& Buckingham, J.: AtLAS OF STEREOCHEMISTRY: THE ABSOLUTE CONFIGURATION OF ORGANIC MOLECULES, 2nd ed., Vol. 1 (to the end of 1971) and Vol. 2 (from 1971 to 1976). (Chapman \& Hall, 1978). Review of the first edition (1974) in B31, 1986.

Lide, D. R. \& Paul, M. A.: Critical evallation of CHEMICAL AND PHYSICAL STRUCTURAL DATA. (US National Academy of Sciences, 1974). This compares various methods for obtaining structural information about molecules.

Melson, G. A. (Ed.): COORDINATION CHEMISTRY OF MACROCYCliC COMPOUNDS. (Plenum, 1979). Review in B36, 2511.

Robertson, J. M. (Ed.): ChemiCal CRystallography. (Butterworth, 1975). Review in B33, 635.

Schuster, P. et al. (Eds.): THE HYDROGEN BOND, Vols. 1, 2 and 3: RECENT DEVELOPMENTS IN THEORY AND EXPERIMENT. (N. Holland, 1976).

Sim, G. A. \& Sutton, L. E. (Eds.): Molecular structure by DIFFRACTION METHODS. This is an annual publication and consists of review articles. Reviews of Vols. 3 and 4 (1975 and 1976) in B33, 318 and B34, 1050. Subsequent Vols. have editors Sutton \& Truter: see below. The publisher is The Royal Society of Chemistry, London.

Speakman, J. C.: Molecular structure: its study by CRYSTAL DIFFraCTION. (The Chemical Society, London, 1977). This is a MONOGRAPH FOR TEACHERS; only 50 pages, but good value.

Sutton, L. E. \& Truter, M. R. (Eds.): Molecular STructure BY DIFFRACTION METHODS. This annual publication consists of review articles addressed primarily to chemists. Vols. 5 and 6 were published in 1977 and 1978; a review of Vol. 6 is in B36, 508. Vols. prior to these were edited by Sim \& Sutton (see above). The publisher is The Royal Society of Chemistry, London.

Symons, M. C. R. (Ed.): AnNuAl Reports OF THE RoYal Society of Chemistry, Vol. 76, 1979, section C. (Royal Society of Chemistry, London, 1980). Ch. 6 in this report gives a condensed but very readable account, by Truter, of the current state-of-the-art of molecular structure determination by diffraction methods. It may be noted that this series has not included the traditional section on crystallography for the past ten years: that role was taken over by the new series of SPECIAL REPORTS which started in 1973 (see Sim \& Sutton, and Sutton \& Truter, above).
Tollenaere, J. P. et al:: A tLAS of THE 3-Dimensional STRUCTURE OF DRUGS. (Elsevier, 1979). Review in B36, 1985.

Trotter, J. et al. (Eds.): STRUCTURE REPORTS. These volumes, which are published annually, cover all crystal structures, not merely molecular structures; they are obtainable from Reidel, Dordrecht, The Netherlands. For more detail, see 29. Tabulations/Data/Bibliography. For a recent review, see A35, 346 or B34, 3847.

Walton, A.: Molecular AND CRYSTal Structure model.s. (Horwood, 1978). Review in B35, 2477.

Note: a new review series, Molecular Interactions. edited by Ratajczak, H. \& Orville-Thomas, W. J. (Wiley, 1980- ).

\section{Neutron Diffraction/Scattering}

Bacon, G. E.: Neutron diffraction, 3rd ed. (OUP, 1975). Review in A32, 749.

Bacon, G. E.: Neutron Physics, 2. (Wykeham, 1970). Review in A28, 222.

Bacon, G. E.: Neutron SCATTERING in CHEMiSTRy. (Butterworth, 1977). This includes neutron diffraction and updates the earlier books that are listed just above. Review in B34, 700.

Bonse, U. \& Rauch, H. (Eds.): NEUTRON INTERFEROMETRY. (OUP, 1979). Review in A36, 1095.

Dachs, H. (Ed.): Neutron diffraction. (Springer, 1978). A basket of review articles. Review in A35, 509.

Dorner, B.: COHERENT INELASTIC NEUTRON SCATTERING IN LATTICE DYNAMICS. (Springer, 1982).

Hoshino, S.: NeUtron Diffraction. (in Japanese). (Kyoritsu Shuppan, 1976).

International Atomic Energy Authority (Ed.): NEUTRON INELASTIC SCATTERING, Vols. 1 and 2. (IAEA, 1978). Review in A35, 348. Vienna symp. proc.

Izyumov, Y. A. \& Ozerov, R. P.: Magnetic NeUtron Diffraction. (Plenum. 1970). Translation from Russian. Review in A27, 301.

Kostorz, G. (Ed.): Neutron Scattering. (Academic Press, 1979).

Larose, A. \& Vanderwal, J.: SCATTERING OF THERMAL NEUTRONS: A BIBLIOGRAPHY, 1932-1974. (Plenum, 1974). Review in A32, 527.

Lovesey, S. W. et al. (Eds.): DYNAMICs OF SOLIDS AND LIQUIDS BY NEUTRON SCATTERING. (Springer, 1977).

Marshall, W. \& Lovesey, S. W.: THEORY OF THERMAL NEUTRON SCATTERING. (OUP, 1971).

Mughabghab, S. F. et al.: Neutron Cross sections, Vol. 1, parts A and B. (Academic Press, 1981). A voluminous compilation of data and references, this is the up-dated version of Mughabghab \& Garber's book of 1973. Vol. 2, giving neutron cross-section curves, is in preparation.

Oles, A. et al. (Eds.): MAGNETIC STRUCTURES DETERMINED BY NEUTRON DifFraCtion. (Orpan-Export, Warsaw, 1976). A data compilation

Sidorov, S. K. \& Goshchitskii, B. N. (Eds.): NeUtRoN DIFFRACTOMETRY OF METALS, ALLOYS AND COMPOUNDS. (in Russian). (Sverdlovsk, 1977).

Squires, G. L.: INTRODUCTION TO THE THEORY OF THERMAL NEUTRON SCATTERING. (CUP, 1978). This can be regarded as the practical man's version of Marshall \& Lovesey, above. Review in A35, 1085. 
Willis, B. T. M. (Ed.): CHEMICAL APPLICATIONS OF THERMAL NEUTRON SCATTERING. (OUP, 1973).

Willis, B. T. M. (Ed.): Thermal NeUtron DifFraCtion. (OUP, 1970).

Windsor, C. G.: Pulsed neutron scattering. (Taylor \& Francis, 1981).

Note also, the use of neutron diffraction for the study of structures in solution: see Symons, in 18. Miscellaneous.

\section{Optical Microscopy}

Beyer, H.: HandBuCh der Mikroskopie. (Verlag Technik, Berlin, 1977).

Bloss, F. D.: The spindle stage. (CUP, 1981). The spindle stage is a simple yet ingenious and invaluable practical device for the microscopist-crystallographer.

Emons, H.-H. et al:: CHEMISChe Mikroskopie. (VEB Deutscher Verlag f. Grundstoffindustrie, 1973).

Girault, J.: CARACTĖRES OPTIQUES DES MINÉRAuX TRANSPARENTS. (Masson, 1980).

Hallimond, A. F.: The polarising Microscope. (Vickers Instruments, York, England, 1970).

Hartshorne, N. H. \& Stuart, A.: Crystals AND the POlarisING MICROSCOPE, 4th ed. (Arnold, 1970).

McCrone, W. C. et al:: Polarised light microscopy. (Ann Arbor Science Publ., 1978).

Marmasse, C.: Microscopes AND THEIR USES. (Gordon \& Breach, 1980).

Michel, K.: Die Grundzüge der Theorie des Mikroskops IN elementarer Darstellung, 3. Aufl. (Wissenschaftliche Verlag, Stuttgart, 1980)

Phillips, W. R.: Mineral OPTICS. (Freeman, 1971).

Richardson, J. H.: OPTICAL MICROSCOPY FOR THE MATERIALS SCIENCES. (Dekker, 1971). Review in J5, 388.

Schumann, H. \& Kornder, F.: ANLeITUNG ZUR allgemeineN UND POLARISATIONS-Mikroskopie dER FestKörPER IM Durchlicht. (E. Schweizerbart'sche, Verlagsbuchhandlung, Stuttgart, 1973).

Shelley, D.: Manual of optical mineralogy. (Elsevier, 1975). Review in A33, 348.

Stoiber, R. E. \& Morse, S. A.: Microscopic identification of CRYSTALS. (Ronald Press, New York, 1972). Review in J6, 251.

Taylor, C. A.: Images. (Wykeham, 1978). This well illustrated, popular book covers much more than just conventional optical microscopy. Review in A35, 254.

Tröger, W. E.: (Edited by Bambauer, H. U. et al.): OPTICAL DETERMINATION OF ROCK FORMING Minerals, Part 1. DETERMINATIVE TABLES. (E. Schweizerbart'sche Verlagsbuchhandlung, Stuttgart, 1979). Teil 2 (TextBand) of this treatise, dated 1967 , is available from the same publisher, in German.

Uytenbogaardt, W. \& Burke, E. A. J.: TABLES FOR MICROSCOPIC IDENTIFICATION OF MINERALS. (Elsevier, 1970). Review in J5, 385.

Wahlstrom, E. E.: Optical CRYSTallography, 5th ed. (Wiley, 1979). Comment in A36, 333.

Wood, E. A.: Crystals and light: an introduction to OPTICAL CRYSTALLOGRAPHY. (Dover, 1977). This is revised from the 1964 edition; a most delightful little book.

\section{Phases/Phase Transformations and Polycrystalline Diffraction}

Alper, A. M. (Ed.): Phase diagrams, Vols. 1-5. (Academic Press, 1970-78).

American Society for Metals: PhaSe TRANSFORMations AND RELATED PHENOMENA IN STEELS. (American Society for Metals, Ohio, 1973).

Bruce, A. D. \& Cowley, R.A.: Structural Phase transiTIONS. (Taylor \& Francis, 1981).

Céolin, R. \& Legendre, B.: InTROduction À L'ÉTUde DES DIAGRAMMES DE PHASES. (Societé d'édition d'enseignement supérieur, Paris, 1974).

Cross, L. E. (Ed.): Phase transition-1973. (Pergamon, 1973).

Domb, C. \& Green, M. S. (Eds.): Phase transitions and CRITICAL PHENOMENa. (Academic Press, 1972).

John, V. B.: UNderstanding PHASE DiAGRAMS. (Macmillan, 1974).

Kaufman, L. \& Bernstein, H.: Computer Calculation of PHASE DIAGRams. (Academic Press, 1970).

Klug, H. P. \& Alexander, L. E.: X-RAY diffraCtion ProcEDURES FOR POLYCRYSTALLINE AND AMORPHOUS MATERIALS, 2nd ed. (Wiley, 1974). This is the up-dated version of the 1954 treatise by these authors. Review in J8, 573.

Kubiak, R. (Ed.): X-RAY PHASE ANALYSIS. (in Polish). (PWN, Warsaw, 1978) One of a series of papers of the Committee of Crystallography of the Polish Academy of Science, dealing with the present state of a given area of crystallography.

Lipson, H. \& Steeple, H.: INTER PRETATION OF X-RAY POWDER DIFFRACTION PATTERNS. (Macmillan, 1970). Review in J5, 146.

Moffatt, W. G.: HandBoOK OF biNaRy PHaSE diagrams. (General Electric Co., NY 12305, USA, 1978).

Müller, K. A. \& Thomas, H.: Structural PHaSe transiTIONS. (Springer, 1981). Review in A38, 397.

Nedoma, J.: INDEXING OF POLYCRYSTALline X-RAY DIAGRAMS FOR TETRAGONAL AND HEXAGONAL SUBSTANCES. (in Polish). (S̀lask, Katowice, 1973).

Paufler, P.: Phasendiagramme. (Akademie-Verlag, 1981).

Rao, C. N. R. \& Rao, K. J.: Phase transitions IN Solids. (McGraw-Hill, 1978). Review in A36, 332.

Riste, T. (Ed.): Nonlinear PHENOMENA AT PHASE TRANSITIONS AND INSTABILITIES. (Plenum, 1982). NATO inst. proc.

Stanley, H. E.: INTroduction to PHASE TRANSITIONS AND CRITICAL PHENOMENA. (OUP, 1971).

Wyryll, C. J.: THE THEORY OF TRANSFORMATIONS IN METALS AND ALlOYS. (Pergamon, 1975).

Zevin, L. S. \& Zavyalova, L. L.: QuAntitative PHASE ANALYSIS. (in Russian). (Nedra, 1974). Review, in English, in $\mathrm{J9}, 513$.

Note: A new journal, Phase Transitjons, edited by Glazer, A. M. \& Smoluchowski, R. (Gordon \& Breach, 1982- ).

\section{Polymers}

Ảlexander, L. E.: X-RAY DIFFRACTION METHODS IN POLYMER SCIENCE. (Wiley, 1970).

Bassett, D. C. (Ed.): Developments In CRYstalline POLYMERS-1. (Applied Science, 1982). 
Battista, O. A.: Microcrystal polymer science. (McGrawHill, 1975).

Blumstein, A.: LIQUid CRYSTALliNe ORDER IN POLYMiRS. (Academic Press, 1978).

Blythe, A. R.: Electrical Properties Of POLYMers. (CUP. 1979).

Ciardelli, F. \& Giusti, P. (Eds.): Structural order in POLYMERS. (Pergamon, 1981).

Fava, R. A. (Ed.): Polymers, Parts A, B and C. (Academic Press, 1980). This is Vol. 16 of a series entitled Methods OF THE eXPerimental sciences; Part B of this Vol. is subtitled CRYSTAL STRUCTURE AND MOR PHOLOGY.

French, A. D. \& Gardner, K. H. (Eds.): Fibre diffraction METHODS. (American Chemical Society, 1980). This is based on the 1979 symp. in Washington. Review in B38, 350 .

Geil, P. H.: Polymer single crystals. (Krieger Publ. Co., Huntington, NY, USA, 1973).

Hall, C.: Polymer materials: an introduction for techNOLOGISTS AND SCIENTISTS. (Macmillan, 1981).

Kakudo, M. \& Kasai, N.: X-RAY diffraction BY polymfrs. (Elsevier, 1972).

Lefkowitz, I. \& Taylor, G. (Eds.): PhaSE TRANSitions IN POLYMERS. (Gordon \& Breach, 1980). Conf. proc.

Lipson, H. (Ed.): Optical transforms. (Academic Press, 1972). Ch. 4 of this book is on the diffraction patterns of polymers and fibres.

McMillan, F. M.: The ChaiN Straighteners: rruitrul INNOVATION: THE DISCOVERY OF LINEAR AND STEREOREGULAR POLYMERS. (Macmillan, 1981).

Miller, R. L.: FLOW-INDUCED CRYSTALLISATION IN POLYMER SYSTEMS. (Gordon \& Breach, 1979).

Samuels, R. J.: The identification, INTERPRETATION AND APPLICATION OF CRYSTALLINE POLYMER STRUCTURE. (Wiley, 1974).

Schultz, J. M. (Ed.): Properties OF SOlid POLYMeriC Materials, Parts A and B. (Academic Press, 1977).

Wunderlich, B.: Macromolecular PHYSics, Vols. 1, 2 and 3. (Academic Press, 1973, 1976 and 1980). The subtitles of these Vols. are: CRYSTALliNe STRUCTURE, MORPHOLOGY, DEFECTS; CRYSTal NUCleation, GROWTH, ANNealing; ANNEALING AND CRYSTAL MELTING, respectively. Vol. 1 is also available in Russian translation (MIR, 1976). Review of Vol. 3 in A37, 606.

\section{Proteins/Macromolecules/Biological}

Arndt, U. W. \& Wonacott, A. J. (Eds.): The Rotation METHOD. (N. Holland, 1977). The 'new' technique for the collection of intensity data. Review in B34, 1049.

Balaban, M. et al. (Eds.): STRUCTURAL ASPECTS OF RECOGNITION AND ASSEMBLY IN BIOLOGICAL MACROMOLECULES, Vols. 1 and 2. (Balaban International Science Services, 1981). Proc. of the Weizmann Inst. conf. of 1980 . Included is a supplement of colour stereoviews, prepared by Feldmann, which can be purchased separately (from Taylor Merchant, NY, USA).

Blundell, T. L. \& Johnson, L. N.: Protein CRystallogRAPHY. (Academic Press, 1976). A superb book. Review in B33, 2702.

CIBA Foundation (Ed.): Molecular interactions and ACTIVITY IN PROTEINS. (Excerpta Medica, 1978).
Dodson, G., Glusker, J. P. \& Sayre, D. (Eds.): STructural STUDIES ON MOLECULES OF BIOLOGICAL INTEREST: A VOLUME IN HONOUR OF DOROTHY HODGKIN. (OUP, 1981).

Fermi, G.' \& Perutz, M.: Hafmoglobin and myoglobin. (Clarendon Press, 1981). This is the second of a series, ATLAS OF MOLECULAR STRUCTURES IN BIOLOGY, which is edited by Phillips, D. C. \& Richards, F. M. This volume is an in-depth presentation of the structures of mammalian haemoglobin and myoglobin, with large excellent diagrams, many being red/green stereo figures. Review in B38, 2096. For Vol. 1 in this series, see Richards, below.

McPherson, A.: Preparation and analysis of PROtein CRYSTALS. (Wiley, 1982).

Nancollas, G. H. (Ed.): Biological Mineralization AND DEMIN'ERALIZATION. (Springer, 1982).

Náráy-Szabo, G. (Ed.): STERIC efFects in Biomolecules. (Elsevier, 1982)

Neidle, S. (Ed.): TOPICS IN NUCLEIC ACID STRUCTURE. (Macmillan, 1981). An overview, from X-ray and NMR studies. This represents the first Vol. of a series that Macmillan have launched, dealing with molecular and structural biology: the 2nd Vol. will also be on nucleic acid structure; the 3 rd will be entitled MOLFCULAR ASPECTS OF ANTICANCER DRUG ACTION.

Porter, R. \& Fitzsimons, D. W. (Eds.): Molecular inTERACTIONS AND ACTIVITY IN PROTEINS. (Excerpta Medica, 1978). Review in B36, 2510.

Richards, F. M. \& Wyckoff, H. W.: RibonuCleaSE. (Clarendon Press, 1973). This is the first of a series, AtLas of MOLECULAR STRUCTURES IN BIOLOGY, which is edited by Phillips, D. C. \& Richards, F. M. For the second, published 1981, see Fermi, above.

Royal Society (London) (Ed.): THE ENZYMES OF GLYCOLYSIS: STRUCTURE, ACTIVITY AND EVOLUTION. (Royal Society, London, 1981). This book is the proc. of a Discussion held in London, in 1981, organised by D. C. Phillips et al., with about 50 participants; it is the hard-cover version of some 200 pages of Philos. Trans.

Sarma, R. H. (Ed.): Biomolecular stereodynamics (two Vols.; Adenine Press, NY 12084, USA, 1981). Conf. proc.

Senechal, M. (Ed.): Structures of MATtER AND PATTERNS IN SCIENCE, INSPIRED BY THE WORK AND LIFE OF DOROTHY Wrinch. (Schenkman Publ. Co., USA, 1980). Symp. proc.

Sherwood, D.: CRYSTALS, X-RAYS AND PRoteInS. (Longman, 1976). A remarkably disappointing book, most of all for anyone interested in proteins. Review in B32, 2732.

Squire, J.: ThF STRUCTURAL BASIS OF MUSCULAR CONTRACTION. (Plenum, 1981). A book essentially for the biologist, which illustrates the crucial role played by the physical methods of X-ray diffraction and EM.

Srinivasan, R. \& Pattabhi, V. (Eds.): Structural aspects of BIOMOLECUles. (Macmillan, India, 1981). Lectures from the Madras winter school of 1978.

Srinivasan, R., Subramanian, E. \& Yathindra, N. (Eds.): BIOMOLECULAR STRUCTURE, CONFORMATION, FUNCTION AND EVolution, Vols. 1 and 2. (Pergamon, 1981). Vol. 1 covers X-ray diffraction and related methods; Vol. 2 deals with other methods.

Note also - for the in-solution, as opposed to the ascrystallised structures of proteins - a very useful article by Williams, R. J. P., describing the evidence of NMR 
studies: THE CONFORMATIONAL PROPERTIES OF PROTEINS IN SOLUTION, in BIOL. REV. (1979), 54, 389-437.

\section{Solid State Chemistry/Crystal Chemistry/General Crystal Structures}

Adams, D. M.: INORGANIC SOLIDS: AN INTRODUCTION tO CONCEPTS IN SOLID-STATE STRUCTURAL CHEMISTRY. (Wiley, 1974).

Bacon, G. E.: The ARChitecture of solids. (Taylor \& Francis, 1981). Review in B38, 1683.

Barrer, R. M.: ZEOLITES \& ClAY MINERALS AS SORBENTS AND MOLeCUlar SIEves. (Academic Press, 1978).

Bokii, G. B. (Ed.): Crystal Chemistry, Vol. 8. Crystal STRUCTURES OF FLUORINE COMPOUNDS. (in Russian) (Moskva, 1972).

Brown, D. B.: MiXed valence compounds. (Reidel, 1980). Review in B38, 349.

Brown, P. J. \& Forsyth, J. B.: The CRystal structures OF SOLIDS. (Arnold, 1973).

Burns, R. G.: Mineralogical applications of CRYSTAL FIELD THEORY. (CUP, 1970). Review in J3, 287.

Burstein, E. (Ed.): A TOMIC STRUCTURE AND PROPERTIES OF Solids. (Academic Press, 1973).

Chojnacki, J.: Elements of PHYSICAL AND CHEMICAL CRYSTAllography. (in Polish). (PWN, Warsaw, 1973). Also available in Czech (Akademia, Praha, 1979).

Clark, G. M.: THE STRUCTURE OF NON-MOLECULAR SOLIDS: A COORDINATED POLYHEDRON APPROACH. (Applied Science, 1972).

Clarke, M. J. et al. (Eds.): StructurE AND BONDing (Springer). More of a journal than a book, this series, edited by a $\sim 6$-member panel, is "issued at irregular intervals, according to the material received'. There are now about 4 or 5 Vols. per year. Only some articles are of direct crystallographic interest: CHEMICAL BONDING IN SOLIDS, in Vols. 18 and 19 (1974); CUBIC STRUCTURE TYPES in Vol. 37 (1979); Monolayers in Vol. 38 (1979); CrystalLOGRAPHY OF TRANSITION METAL HYDRIDES in Vol. 44 (1980); Ferrites in Vol. 47 (1981); and STaCked Metal COMPlexes in Vol. 50 (1982). Reviews of Vols. 7, 8, 37 and 44 in B26, 1638; B27, 1839; B37, 1480; and B38, 1684.

Dereń, J. et al:: Chemistry of solids. (in Polish). (PWN, Warsaw, 1977)

Donohue, J.: The structures of the elements. (Wiley, 1974). Review in B31, 334.

Dorain, P. B.: Symmetrie Und anorganische StrukturCHEMIE. (Vieweg, 1972).

Dunitz, J. D.: X-RAY aNalysis and THE STRUCture of ORGANIC MOLECUles. (Cornell Univ. Press, 1979). This book, addressed principally to the organic chemist, is the sequel to J. M. Robertson's book of 1953, OrGanIC CRYSTALS AND MOLECULES. X-ray analysis has advanced a lot in 26 years. Review in B37, 493.

Dunitz, J. D. \& Ibers, J. A., (Eds.): Perspectives in Structural ChEMISTRY, Vol. 3. (Wiley, 1971). Review in B27, 1481.

Dunitz, J. D. et al. (Eds.): STRuCture AND Bonding. (Springer). Vols. 11 to 42 of this series were edited by Dunitz et al.; from Vol. 44 (1981), the editors are Clarke et al., and further details are given under that name, above.
Evans, R. C.: Einführung in die Kristallchemie. (de Gruyter, 1976). This is a translation of the well known English book.

Fair, H. D. \& Walker, R. F. (Eds.): ENERGETIC MAterials, Vols. 1 and 2. (Plenum, 1977). These two volumes are exclusively on the inorganic azides. Review in B34, 3846.

Franks, F. (Ed.): WATER IN CRYSTALLINE HYDRATES. (Plenum, 1973).

Galasso, F. S.: Structure and Properties of INORGanic SOLIDS. (Pergamon, 1970). This has a useful bibliography and good illustrations.

Garner, C. D. \& Seddon, K. R.: Transition-metal ChemisTRY REVIEW, 1979. (Elsevier, 1981). This is simply Vols. 35 and 37 of the journal CoORD. CHEM. Rev. Review in B38, 1684.

Gilinskaya, E. A. (Ed.): Crystal Chemistry, Vol. 11. (in Russian). (Moskva, 1976).

Gladyshevskii, E. J.: CRYSTAL ChEMISTRY OF SILICIDES AND GERMANIDES. (in Russian). (Metallurgija, 1971).

Greenwood, N. N.: IonEnkristalle, GitTerdefek TE UND NiCHTSTÖCHIOMETRISCHE VeRBindUNGEN. (Verlag Chemie, 1973). Translation from English.

Hannay, N. B.: Chemistry of the solid state. (in Polish translation) (PWN, Warsaw, 1972).

Hannay, N. B. (Ed.): TREatise ON SOldD STATE ChEMISTRY, Vols. 1-6. (Plenum, 1973-1976). Review of Vol. 3 in B33, 2001.

Harrison, W. A.: Electronic STRUCtURE AND THE PROPERTIES OF SOLIDS: THE PHYSICS OF THE CHEMICAL BOND. (Freeman, 1980).

Hayes, W. (Ed.): Crystals With the fluorite structure. (OUP, 1975).

Hemmerich, P. et al. (Eds.): STRUCTURE AND BONding. (Springer). Vols. 1-10 of this series were edited by Hemmerich et al:; from Vol. 44 (1981), the editors are Clarke et al., and further details are given under that name, above.

Holt, S. L. et al. (Eds.): SOLID STATE CHEMISTRY: A CONTEMPORARY OVERVIEW. (American Chemical Society, 1980). Based on a symp. of 1978. Review in B38, 348.

Hulliger, F.: STRUCTURAL CHEMISTRY OF LAYER-TYPE PHASES. (Reidel, 1977). Review in B35, 793. This is Vol. 5 of Reidel's series of seven Vols. on layered materials; for the others, see Lee, Lévy, Lieth and Wieting, in 11. Materials and their Properties/General Materials Science.

Kaluski, Z. \& Kosturkiewicz, Z. (Eds.): ORGANIC CRYSTAL CHEMISTRY. (Poznan, 1979 and 1980). Proc. of two symp.

Kepert, D. L.: INORGANIC STEREOChEMISTRY. (Springer, 1982). This is a systematic, detailed survey of the structures of metal coordination compounds.

Kitaigorodskii, A. I.: MIXED CRYSTALS. (Springer, expected 1982).

Kitaigorodskii, A. I.: MOLECULAR CRYSTALS AND MOLECULES. (Academic Press, 1973). A unique study of the packing of molecules in the crystalline state, it is somewhat up-dated in the recent German text, listed just below.

Kitaigorodskii, A. I.: Molekül Kristalle. (Akademie-Verlag, 1976). Review, in German, in B36, 2194.

Kornilov, N. I. \& Matveeva, N. A. (Eds.): Metalloids: STRUCTURE, PROPERTIES AND APPLICATIONS. (in Russian). (Nauka, 1971). A set of papers.

Krebs, H.: Principles of CRYSTAL ChEMISTRY OF INORGANIC compounds. (in Russian). (MIR, 1971). 
Ladd, M. F. C.: Structure aNd bonding in Solid state CHEMISTRY. (Horwood, 1979). Review in B37, 492.

Lévy, F. (Ed.): CRYSTallograpHy AND CRYSTAL CHEMISTRY OF MATERIALS WITH LAYERED STRUCTURFS. (Reidel, 1976). Review in B33, 2351. See also Hulliger, above.

Lévy, F. (Ed.): INTERCALATEd layered Materials. (Reidel, 1979). See also Hulliger, above.

Lieth, R. M. A. (Ed.): Preparation and CRystal growth OF MATERIALS WITH LAYERED STRUCTURES. (Reidel, 1977). Review in B34, 3948. See also Hulliger, above.

McKie, D. \& McKie, C.: CRYstalline solids. (Nelson, 1974). A text giving particular attention to the physics rather than the chemistry of the solid state. A long review in A31, 397.

Malinovskii, T. I. (Ed.): CRYSTAL CHEMISTRY OF INORGANIC Compounds. (in Russian). (Shtiinca, Kishinev, 1976). A set of articles.

Marshall, R. C.: Silicon CARbide 1973. (Univ. of S. Carolina Press, 1973). Conf. proc.

Matkovich, V. I. (Ed.): BORON AND BORIDES. (Springer, 1977). Review in B35, 793.

Megaw, H. D.: CRYSTAl structures: a WORKING APPROACH. (Saunders, 1973). A mine of information, and guidance, on structures such as ilmenite, feldspar and ice, yet curiously (in view of its quite general title) silent on the immense world of molecular crystals. Review in A30, 605, or B30, 1887.

Meyer, K.: Physico-chemical CRystallography. (Russian translation from German) (Metallurgija, 1972).

Muller, O. \& Roy, R.: Crystal Chemistry of NON-METAllic MATERIALS, Vol. 4. THE MAJOR TERNARY STRUCTURAL FAMILIES. (Springer, 1974).

Nishiyama, Z.: MARTENSITIC TRANSFORMATION. (Academic Press, 1978).

O'Keeffe, M. \& Navrotsky, A. (Eds.): STruCture AND BONDING IN CRYSTALS, Vols. 1 and 2. (Academic Press, 1981). This book, which is a survey of recent developments, is in celebration of the 50-year anniversary of the original publication of Pauling's Rules.

Parthé, E.: Cristallochemie des STRuctures tétraédriQUES. (Gordon \& Breach, 1972).

Roberts, I. F.: CRYSTALS AND THEIR STRUCTURES. (Methuen, 1974).

Rooijmans, C. J. M. \& Rabenau, A. (Eds.): Crystal strucTURE AND CHEMICAL BONDING IN INORGANIC CHEMISTRY. (N. Holland, 1975). Review in A33, 349.

Saito, Y.: INTRoduction to Chemical CRYSTAllography. (in Japanese). (Kyoritsu Shuppan, 1975).

Samsonov, G. V.: THE Oxide HANDBOOK. (Plenum, 1973). Review in $\mathbf{J} 7,94$.

Schmalzried, H.: Solid STATE REACtions (revised 2nd ed.). (Verlag Chemie, 1981).

Schubert, K.: CRystal structures of two-COMPONENT PHASES. (in Russian translation) (Metallurgija, 1971).

Schuster, P. et al. (Eds.): THE HYDROGEN BOND: RECENT DEVELOPMENTS IN THEORY AND EXPERIMENT, Vols. 1, 2 and 3. (N. Holland, 1976).

Sirota, N. N. (Ed.): Chemical bonds IN solids, Vols. 1-4. (Plenum, 1972). These are translated from Russian.

Sowerby, D. B. (Ed.): MAIN GRoup Chemistry REVIEw, 1979. (Elsevier, 1981). This is simply Vol. 34 of the journal Coord. Chem. Rev.. Review in B38, 1684.
Suchet, J. P.: ChEMISTRy AND SEMICONDUCTION IN TRANSITION METAL BINARY COMPOUNDS. (Academic Press, 1971).

Trotter, J. (Ed.): STRUCTURE REPORTS. Volumes are pubished approximately annually; thus, Vol. 44A and B (inorganic and organic, respectively) covering the year 1978 were published in 1980 . Review of the latest issues in B34, 3847 and A35, 346.

Van Meersche, M. \& Feneau-Dupont, J.: Introduction À LA CRISTALlographIE ET À LA CHIMIE STRUCTURALE. (Oyez, 1976).

Vinogradov, A. P. (Ed.): Problems of ISOMOR Phous SUbST1TUTIONS OF ATOMS IN CRYSTALS. (in Russian). (Nauka, 1971).

Walton, A.: MOleCUlar AND CRYSTAL STRUCTURE MODELS. (Horwood, 1978). Review in B35, 2477.

Wells, A. F.: Further STUdies OF THREE-DIMENSIONAL NETS. (American Crystallographic Association Monograph No. 8, 1979).

Wells, A. F.: Models in Structural INORGanic CHEMISTRY. (OUP, 1970).

Wells, A. F.: Structural inorganic chemistry, 4th ed. (OUP, 1975). Review in B32, 985.

Wells, A. F.: ThreE-dimensional nets and POLyHedra. (Wiley, 1977). Review in B34, 2958.

Wood, J. et al. (Eds.): REACTIVITY OF SOLIDS. (Plenum, 1977). Review in B34, 3497. Int. symp. proc.

Zadneprovskii, G. M. et al.: CRystallochemical RULES IN URANIUM FLUORIDES AND THEIR ANALOGUES. (in Russian). (Atomizdat, 1975).

Zannetti, R. \& Celotti, G.: Elementi di STRUTtURISTiCA chimica diffrattometrica. (Editrice Piccin, Padova, 1969).

Zeeman, J.: ChimiE CRISTALline. (Dunod, 1970). Translated from the original German, by Bertaut. A small but excellent text on basic crystal chemistry. Review in B27, 251 .

\section{Student-Oriented Texts/Books for Students}

Bacon, G. E.: The architecture of solids. (Taylor \& Francis, 1981). Review in B38, 1683.

Bardsley, W. et al. (Eds.): CRYSTAL GROWTH: A TUTORIAL APPROACH. (N. Holland, 1979). Despite inelegant print and production, this is a good text on the controlled production of quality crystals for technological applications.

Battey, M. H.: Mineralogy for students. (Oliver \& Boyd, 1975).

Bogdanow, R. W.: VoM MOLEKül zUM KRISTALl. (Akademie Verlag Geest \& Portig, Leipzig, 1976).

Bojarski, Z. et al.: TUTORIAL MATERIALS ON CRYSTALLOGRAPHY. (in Polish). (Katowice, 1976).

Borchardt-Ott, W: KRISTAllographIE: EINE EINFüHRUNG FÜR NATURWISSENSCHAFTLER. (Springer, 1976). Review, in German, in B33, 2988.

Brostow, W.: Science of materials. (Wiley, 1979). A good general text on materials.

Brown, M. A.: X-RAY methods. (Merrow, 1971). Quite general and very simple.

Bullen, G. J. \& Greenslade, D. J. (Eds.): Problems IN MOLECUlar STRUCTURES. (Chapman \& Hall, 1982). This 
surveys a very wide range of different methods for the determination of structures.

Buerger, J. M. Introduction to CRYSTAL GEOMETRY. (McGraw-Hill, 1971. For Buerger's other books see 7. General Crystallography.

Burns, G. \& Glazer, A. M.: Space GROUPS fOR SOlid STATE SCIENTISTS. (Academic Press, 1978). Review in J12, 428.

Burzlaff, H. \& Zimmermann, H.: SyMmETrieleHrE. (Thieme, Stuttgart, 1977). One of the best texts on the subject (in German).

Cartmell, E.: Principles of CRystal Chemistry. (The Chemical Society, London, 1971). This is one of the MONOGRAPHS FOR TEACHERS.

Chojnacki, J.: ElEMENTS OF PHYSICAL AND CHEMICAL CRYSTallography. (in Polish). (PWN, Warsaw, 1973). Also available in Czech (Akademia, Praha, 1979). Of the various Polish language texts listed here in this section, this one "has the most original approach, especially to crystal geometry, crystal chemistry and crystal physics'.

Close, K. J. \& Yarwood, J.: AN INTRODUCTION TO SEMICONDUCTORS. (Heinemann, 1971).

Cullity, B. D.: Elements of X-Ray diffraction. (Addison Wesley, 1978). Despite the generality of the title, this book is addressed, apparently, only to metallurgy students.

Curien, H.: Les groupes en CRISTAllographie. This is in Kahan, Th.: THÉORIE DES GROUPES ET PHYSIQUE CLASSIQUE ET QUaNTIQUE, Tome 2. (Dunod, 1971). For postgraduate students.

Delepine, C.: Introduction À LA CRISTAllographie. (Dunod, 1971).

Dent Glasser, L. S.: Crystallography and its applicaTIONS. (Van Nostrand, 1977). An excellent text for students. Review in B34, 1750.

Dorain, P. B.: Symmetrie UND ANORGanische StrukturCHEMIE. (Translated from English). (Akademie Verlag, 1972). Also available in Polish (PWN, Warsaw, 1968).

Ducros, P.: Radiocristallogra Phie. (Dunod, 1971).

Ducros, P. \& Lajzerowicz-Bonneteau, J.: Problèmes DE CRISTALlographie. (Dunod, 1967).

Durski, Z.: Principles of X-Ray Crystallography and STRUCTURe aNalysis OF CRYSTALS. (in Polish). (Warszawa, 1973).

Egert, E. \& Lindner, H. J.: STRUKtUREN DER MAteriE UND IHRE Symmetrie. (R. Schmidt, Nieder-Ramstadt, 6101, Federal Republic of Germany, 1976). A booklet of rather good stereopictures. Review, in English, in B33, 2352.

Engels, F.: Elements of Crystallography. (in Polish). (Gliwice, 1975).

Gabis, V:: Manipulations, eXerCICES, PROBlèmes CORRIGÉs À L'USAGE DES ENSEIGNANTS EN MINÉRALOGIE, CRISTALLOGRAPHIE, SCIENCES DES MATÉRIAUX. (Société Française de Minéralogie, 1980).

Glusker, J. P. \& Trueblood, K. N.: Crystal structure ANALYSIS: A PRIMER. (OUP, 1972). Easy to read, and with almost no mathematics, this book approaches X-ray diffraction from optical diffraction and Fourier transform concepts. Review in A28, 680 .

Guinier, A.: STRuCTURE DE LA MA TIĖRE - DU CIEL BLEU À LA MATIÉRE PLASTIQUE. (Hachette, 1980). This is a beautifully written and beautifully illustrated book for schools, relating structure at the atomic level to all aspects of the everyday world. Review, in English, in A38, 559 and B38, 1685.

Guy, A. G.: Essentials of materials science. (McGrawHill, 1976). This is very readable, well-illustrated, and gives useful attention to the applications of materials.

Harburn, G. et al:: Atlas of optical transforms. (Bell \& Hyman, 1975). Almost entirely pictorial; what text there is is in both English and French. This book can usefully be studied in conjunction with Lipson's OPTICAL TRANSFORMS (see below). Review in B32, 1622.

Harsch, G. \& Schmidt, R.: KristallgeOmetrie: PaCkUngen UND SYMMETRIE IN STEREODARSTELLUNGEN. (Diesterweg/Salle/Sauerländer Verlag, 1981).

Hart-Davis, A.: SOlids: AN INTRODUCTION. (McGraw-Hill, 1975).

Heymann, P.: Théorie dyNamiQue de la microscopie eT difFraction Électronique. (PUF, Patis, 1974).

Hudson, M.: CR ystals AND CRYSTAL STRUCTURE. (Longman, 1971). A very elementary text. Nice illustrations.

Hukins, D. W. L.: X-RAY DIFFRACTION BY DISORDERED AND ORDFRED SYSTEMS. (Pergamon, 1981). This fairly simple presentation extends across the whole range of types of materials, from single crystals, to polycrystalline aggregates, to liquid crystals, polymers, fibres, amorphous materials and liquids. Review in B38, 2097.

IUCr Commission on Crystallographic Teaching: Booklets ('pamphlets') on various aspects of crystallography. The general editor is C. A. Taylor. There are currently ten booklets available; each independent, on different topics and by different authors, they are written at very different levels. Nos. 2-4 are the best, No. 1 the simplest. They are obtainable, separately if required, and quite cheaply, from the University College Cardiff Press, CF1 1XL, UK. A further set of ten booklets is expected in late 1982.

IUCr Commission on Crystallographic Teaching: A list of publications on the teaching of crystallography. (expected 1982).

Jelenkowski, J. \& Wesołowski, K.: Practice IN X-RAY STRUCTURE ANalysis. (in Polish). (Kraków, 1978).

Jost, K.-H.: RöNTGENBEUGUNG AN KRISTALlEN. (AkademieVerlag, 1975). Review, in English, in A32, 749.

Julg, A.: Crystals as giant mOlecules. (Springer, 1978). This booklet tries to show the application of the MO approach to extended assemblies of atoms. Review in B35, 1540.

Kakudo, M. \& Sasada, Y.: INTRODUCTION to X-RAY ANALYsis, 2nd ed. (in Japanese). (Tokyo Kagaku Dojin, 1975).

Keller, E.: Wachstum und Aufbau der Kristalle. (Aulis Verlag Deubner, Köln, 1980).

Kennon, N. F.: Patterns in CRystals. (Wiley, 1978). This was intended, no doubt, to be an original presentation, crystal clear, for beginners; it succeeds in the first but not the second of these objectives. Review in A36, 500.

Kitaigorodskii, A.: ORDER AND DISORDER IN THE WORLD OF ATOMS. (MIR, 1979).

Kleber, W.: AN INTRODUCTION TO CRYSTALlOGRAPHY. (VEB Verlag, 1970). Review in A28, 221. This is the English version of a text that has been well known in Germany since 1956, during which time there have been many successive editions. The latest German edition is listed just below.

Kleber, W.: Einführung in diE Kristallographie. (VEB Verlag, 1977). 
Kozlova, O. G.: GrowTH AND MORPHOLOGY OF CRYSTALS. (in Russian). (Izd-vo Mosk. Univ-ta, 1980). Suitable for undergraduates and postgraduates of geology or materials science backgrounds.

Kubisz, J. \& Żabiński, W.: Tutorial MATERIALS ON MINERALOGY. (in Polish). (Kraków, 1978).

Kushta, G. P.: Introduction to Crystallography. (in Russian). (Lvov, 1976). A textbook for students of physics and chemistry.

Lipson, H.: Crystals and X-RaYs. (Wykeham, 1970). Review in A27, 507.

Lipson, H. (Ed.): Optical tRansforms. (Academic Press, 1972). This book discusses many different applications of the concept of the Fourier transform; Ch. 10 is especially devoted to the use of optical transforms in teaching. See also Harburn, above.

Luger, P.: MODERN X-RAY ANALYSIS ON SINGLE CRYSTALS. (de Gruyter, 1980). This up-to-date text is highly recommended by the review: B37, 492 .

McKie, D. \& McKie, C.: Crystalline solids. (Nelson, 1974). A student text particularly concerned with the physical aspects of crystalline matter. Review in A31, 397.

Milburn, G. H. W.: X-RAY CRYSTALLOGRAPHY. (Butterworth, 1973). Review in A29, 583.

Paufler, P. \& Leuschner, D.: Kristallogra Phische GrundBEGRIFFE DER FESTKÖRPER PHYSIK. (Vieweg, 1975). A short introduction, addressed primarily to students of physics.

Penkala, T:: Outline of CRYSTAllography. (PWN, Warsaw, 1977).

Phillips, D. C. \& North, A. C. T.: Protein structure. (OUP, 1973). A 30-page booklet, with excellent diagrams, including red/green stereos.

Rigault, G.: INTRODUZIONE ALLA CRISTALlografia. (Libreria Editrice Levrotto e Bella Universitaria Torino, 1976).

Rigault, G. \& Graziosi, G.: COMPITI ED FSERCITAZIONI DI CRISTALlogRAFIA. (Libreria Editrice Levrotto e Bella Universitaria Torino, 1972).

Roberts, I. F.: CRystals AND THEIR STRuCTURES. (Methuen, 1974). An extremely simple booklet.

Saito, Y.: Introduction to ChEMical CRYSTallography. (in Japanese). (Kyoritsu Shuppan, 1975).

Sands, D. E.: Introduction to Crystallography. (Benjamin, 1975).

Schlenker, B. R.: INTRODUCTION TO MATERIALS SCIENCE. (Wiley, 1974). This is the revised SI edition. An excellent student text on materials science from an engineer's point of view.

Schultz, J. M.: Diffraction For MATERIALS SCIENTISTS. (Prentice Hall, 1981). A comprehensive treatment.

Senczyk, D.: Laboratory PRaCtice in X-RaY STRUCTURE ANALYSIS. (in Polish). (Poznań, 1974).

Shaskol'skaya, M. P.: Crystallography. (in Russian). (Vysshaya Shkola, 1976). Review, in English, in J12, 139

Skrzat, Z: Elements of CRYstallography. (in Polish). (Torun, 1980).

Smith, J. V.: GeOMETRICAL AND STRUCTURAL CRYSTALlOGRAPHY. (Wiley, 1982). Though omitting organic substances almost totally, this is a very attractive teaching text.

Speakman, J. C.: Molecular STRucture: itS STUdy BY CRYSTAL DIFHRACTION. (The Chemical Society, London, 1977). A MONOGRAPH FOR TEACHERS; just 50 pages, but good material.
Speakman, J. C.: THE HYDROGEN BOND AND OTHER INTERMOLECUlAR FORCES. (The Chemical Society, London, 1975). Another MoNOGRAPH FOR TEACHERS; just 30 pages, and almost all on the hydrogen bond.

Steadman, R.: Crystallography. (Van Nostrand, 1982). An inexpensive step-by-step paperback on XRD and ED patterns, full of diagrams and exercises for students of materials science.

Stiddard, M. H. B.: The elementary language of SOlid STATE. PHYsics. (Academic Press, 1975). Not at all as elementary as the title might lead one to expect.

Stout, G. H. \& Jensen, L. H.: X-RAY STRUCtURE DETERminaTION: A PRACTICAL GUIDE. (Macmillan, 1972). Originally published in 1968 but still much in use, this is the 5th printing of this classic.

Taylor, C. A. et al:: BoOKlets on crystallography, produced by the IUCr Commission on Crystallographic Teaching. See the entry above, under IUCr.

Toropov, N. A. \& Bulak, l. N.: Crystallography AND MINERALOGY. (in Russian). (Leningrad, 1972). A textbook for students of chemistry, it contains the elements of crystallography, mineralogy and geology.

Vainshtein, B. K. et al.: MODERN CRYSTALLOGRAPHY, Vols. 1, 2, 3, and 4. This is being published first in Russian: Vols. 1, 2 and 3 are in print (Nauka, 1980); Vol. 4 is expected soon (Nauka, 1981). Meantime, Vols. 1 and 2 have already appeared in English (Springer, 1981). Although Vainshtein is the principal author of this series, the authors of Vol. 3 are Chernov, A. A. et al., and of Vol. 4, Shuvalov, L. A. et al. Review of Vol. 1 in A36, 1095.

Van Meersche, M. \& Feneau-Dupont, J.: Introduction ’̀ LA CRISTALlograpHIE ET À LA CHIMIE STRUCTURALE. (Oyez, 1976).

Vladimirov, V. I.: PHYSICAL THEORY OF PLASTICITY AND STRENGTH, Vol. 1: CRYSTAL DEFECTS. (in Russian). (Leningrad, 1973). Record of lectures.

Weigel, D.: CRistallographie et STRucture DES SOlides. (Masson, 1972).

Wells, A. F.: Structural inorganic chemistry, 4th ed. (OUP, 1975). Review in B32, 985.

Whittaker, E. J. W.: CRYSTALlOGRAPHY: AN INTRODUCTION FOR EARTH SCIENCE (AND OTHER SOLID STATE) STUDENTS. (Pergamon, 1981). Review in A38, 560.

Wilson, A. J. C.: Elements of X-RAY CRystallography. (Addison Wesley, 1970). Review in A27, 190.

Windle, A.: A first course in' Crystallography. (Bell \& Hyman, 1976). Very brief and very elementary.

Wood, E. A.: CRYSTALS: a HandBoOK FOR SCHOOL tEACHERS. (IUCr, 1972). This 60-page booklet was written for the IUCr Commission on Crystallographic Teaching.

Woodhead-Galloway, J.: COLlaGEN: THE ANATOMY OF A PROTEIN. (Arnold, 1980).

Woolfson, M. M.: Introduction to CRYSTALlography. (CUP, 1978). This is the paperback reprint of the successful book of 1970, reviewed at that time in A26, 461 .

Zagalskaja, Yu. G. \& Litvinskaja, G. P.: GeomeTriC MICroCRYSTALlOGRAPHY. (in Russian). (Izd-vo Mosk. Univ-ta 1976). This is a set of over 200 problems, with an introduction.

Zorkii, P. M. \& Afonina, N. N.: SyMmetry of MOLECUleS AND CRYSTALS. (in Russian). (Izd-vo Mosk. Univ-ta, 1979). 


\section{Surfaces}

Blakely, J. M.: InTROduCtion to THE PROPERTIES OF CRYSTAL SURFACES. (Pergamon, 1973). Review in J7, 513.

Blakely, J. M. (Ed.): SuRfaCe PhySiCS OF MATERIALS, Vols. 1 and 2. (Academic Press, 1975). Review in J9, 514.

Bootsma, G. A. \& Geus, J. W. (Eds.): The solid-vacuum INTERFACE, 3. (N. Holland, 1975).

Bourdon, J. (Ed.): GROWTH AND PROPERTIES OF METAL CLUSTERS. (Elsevier, 1980). Conf. proc.; application to catalysis and the photographic process especially. Review in A37, 141.

Brundle, C. R. \& Todd, C. J. (Eds.): Adsorption at SOLID SURFACES. (N. Holland, 1976).

Cullen, G. W. et al:: Vapour growth and epitaxy. (N. Holland, 1975). Conf. proc. Review in J10, 212.

Day, D. E. (Ed.): Glass surfaces. (N. Holland, 1976).

Dupuy, C. H. S. \& Cachard, A. (Eds.): Physics of NONMETALLIC THIN Fllms. (Plenum, 1976). Lectures of a NATO summer school. Review in A33, 350.

Ertl, G. \& Küppers, J.: Low ENERGY ELECTRONS AND SURFACE CHEMISTRY. (Verlag Chemie, 1974).

Heinz, K. et al:: STRUCTURAl STUdies OF SURFACES. (Springer, 1981).

Höhler, G. (Ed.): Structural studies of surfaces. (Springer, 1982).

Hölzl, J. et al:: Solid surfaCe PHysics. (Springer, 1979). Review in A35, 1088.

Ibach, H. (Ed.): ELECTRON SPECTROSCOPY FOR SURFACE ANALYSIS. (Springer, 1977).

International Atomic Energy Agency (Ed.): SURFACE SCIENCE, Vols. 1 and 2. (IAEA, 1975). Review in A33, 348. Lectures presented at an international course in Trieste, 1974.

Kane, P. F. \& Larrabee, G. B. (Eds.): Characterisation OF SOLID SURFACES. (Plenum, 1974).

King, D. A. \& Woodruff, D. P. (Eds.): The CHEMICAL PHYSICS OF SOLID SURFACES AND HETEROGENFOUS CATALYSIS, Vol, 1. (Elsevier, 1981). A further three Vols. are to come.

Kressel, H. (Ed.): Characterisation OF EPITAXIAL FILMS. (Elsevier, 1976). Review in J10, 211.

Lantanision, R. M. \& Courtel, R. J. (Eds.): AdvanCES IN THE MECHANICS AND PHYSICS OF SURFACES, Vol. 1. (HarwoOd, 1981).

McColl, J. L. \& French, P. M. (Eds.): Inter Pretative TECHNIQUES FOR MICROSTRUCTURAL ANALYSIS. (PlenUm, 1977). Symp. proc. Review in J10, 510.

Meyer, O. et al. (Eds.): ION BEAM SURFACE LAYER ANALYSIS, Vol. 1. (Plenum, 1976).

Neumann, G. \& Neumann, G. M.: Surface SElf-Diffusion of METALS. (Diffusion Information Centre, Switzerland, 1971). Review in J5, 443.

Ondar, J.: Physics AND ChEMISTRY OF SURFACEs. (Blackie, 1975).

Oostrom, A. G. L. van \& Sparnaay, M. J. (Eds.): THE SOLID-VACUUM INTERFACE, 4. (N. Holland, 1976).

Pendry, J. B.: LEED: THE THEORY AND ITS APPLICATION. (Academic Press, 1974). Review in J8, 403.

Prutton, M.: Surface PHysics. (Clarendon, 1975). Review in J9, 372.

Reed, S. J. B.: EleCtron-PROBE MICROANALYSIS. (CUP, 1975). Review in A32, 175.
Rhodin, T. N. \& Ertl, G. (Eds.): The naturE OF THE SURFACE CHEMICAL BOND. (N. Holland, 1979). Review in A36, 1093.

Roberts, M. W. \& Thomas, J. M. (Eds.): CHEMICAL PHysics OF SOLIDS AND THEIR SURFACES, Vols. 4, 5, 6, 7, and 8 . (Prior to Vol. 7, the title of this series was Surface AND DEFECT PROPERTIES OF SOLIDS). (The Chemical Society, London, 1975, 1976,1977, 1978, and 1980, respectively). Reviews in A33, 925; A35, 479; A35, 831; A36, 157; and (Vol. 8) A38, 173.

Seifert, H.: Strukturgelenkte GrenzFläChenVorgänge (Vieweg, 1971).

Sinha, S. K. (Ed.): ORDERING IN Two dimensions. (N. Holland, 1981). Conf. proc.

Somorjai, G. A.: Chemistry in two dimensions. (Cornell 1981).

Somorjai, G. A.: The STRuCture AND Chemistry of SOlid SURFACES. (Wiley, 1969).

Somorjai, G. A. \& Van Hove, M. A.: AdSORBED MONOLAYERS ON SOLID SURFACES. This is a chapter in STRUCTURE AND BONDING, Vol. 38. (Springer, 1979).

Tomashpolsky, Yu. Ya. \& Platonov, G. L.: Ferroelectric FILMS OF METALLIC COMPLEX OxIDES. (in Russian). (Soviet Metallurgy, 1978). Review, in English, in J13, 636.

Van Hove, M. A. \& Tong, S. Y.: SurfaCE CRYSTALlOGRAPHY BY LEED. (Springer, 1979). Review in J12, 641.

Woodruff, D. P.: THE SOLID-LIQUID INTERFACE. (CUP, 1980). This is a soft-cover reprint of the book of 1973 .

Note: Two new journals, both from 1981: SURFACE SCIENCE REPORTS ( $N$. Holland) and Solids AND Surfaces (Springer), the latter being the newly designated Part A of the journal APPLIED PHYSICS.

\section{Symmetry}

Abbott, E. A.: Flatland: a Romance of Many dimensions. (Blackwell, 1978). 'A most delightful book'.

Altmann, S.: INDUCED REPRESENTATIONS IN CRYSTALS AND MOLECULES. (Academic Press, 1977). This is not a book for beginners. Review in A36, 834.

Belov, N. V. el al.: THE SPACE groups atLAS OF THE CUBIC SYSTEM. (Nauka, 1980). In a formal sense, this is an addendum to the INTERNATIONAL TABLES of the IUCr.

Bernal, I., Hamilton, W. C. \& Ricci, J. S.: Symmetry: A STEREOSCOPIC GUIDE FOR CHEMISTS. (Freeman, 1972). This is limited to plane groups and point groups; with one or two exceptions, the examples and stereo-diagrams are very helpful. Review in B29, 924.

Boardman, A. D. et al:: SYMMETRY AND ITS APPLICATIONS IN SCIENCE. (McGraw-Hill, 1973).

Borsdorf, R. et al:: EINFÜHRUNG IN DIE MOLEKülsYMMETRIE. (Geest \& Portig, Leipzig, 1973).

Bourgoin, J.: ARABIC geOMETRICAL PATTERNS AND DESIGN. (Dover, 1973).

Bradley, C. J. \& Cracknell, A. P.: ThE MAthematical THEORY OF SYMMETRY IN SOLIDS. (OUP, 1972).

Brown, H. et al:: CrystallographIC GROUPS OF 4-DIMENSIONAL SPACE. (Wiley, 1978). Review in A36, 331.

Buerger, M. J.: INTRODUCTION TO CRYSTAL GEOMETRY. (McGraw-Hill, 1971).

Burns, G. \& Glazer, A. M.: SPACE GRoups For SOldD STATE SCIENTISTS. (Academic Press, 1978). Review in J12, 428. 
Burzlaff, H. \& Zimmermann, H.: Symmetrielehre. (Thieme, Stuttgart, 1977). One of the best texts on the subject (in German).

Butler, P. H.: PoINT GRoup SyMmeTry APPliCATIONS: METHODS AND TABLES. (Plenum, 1981). This book is addressed to group theory mathematicians rather than to crystallographers.

Clarke, P. T.: STANDARD STEREOGRaMS FOR MATERIaLS SCIENTISTS. (AN ATLAS OF STEREOGRAPHIC PROJECTIONS). (HMSO, London, 1976). This is primarily for the interpretation of electron diffraction patterns; but the review did not think it particularly useful: J10, 509 .

Davenport, A. T. \& Booth, A. R.: Stereggraphic projecTIONS. (Butterworth, 1970). Review in J4, 405.

Dmitriev, 1. S.: Symmetrie IN der Wel.t der Moleküle. (VEB Deutscher Verlag f. Grundstoffindustrie, 1979).

Donaldson, J. D. \& Ross, S. D.: SYMmetry AND STEREOCHEMISTRY. (Blackie, 1972).

Dorain, P. B.: Symmetrie Und anorganische StrukturCHEMIE. (Vieweg, 1972).

Elliott, J. P. \& Dawber, P. G.: SYMmeTRY IN Physics, Vols. 1 and 2. (Macmillan, 1979).

Fedorov, E. S.: SYMMETRY OF CRYSTALS. (American Crystallographic Association, 1971). This has been translated from the Russian by David and Katherine Harker.

Fisher, W., Burzlaff, H., Hellner, E. \& Donnay, J. D. H.: SPACE GROUPS AND LATTICE COMPLEXES. (National Bureau of Standards, USA, 1971).

Flurry, R. L.: SyMmetry GROUPS: THEORY AND APPLICATIONS. (Prentice Hall, 1980).

Gruber, B. \& Millman, R. S.: Symmetries IN SCIENCE. (Plenum, 1980).

Haussühl, S.: Kristallgeometrie. (Verlag Chemie, 1977).

Holden, A.: Shapes, SPACE AND SYMMETRY. (Columbia Univ. Press, 1973).

Hollas, J. M.: Die Symmetrie von Molekülen. (de Gruyter, 1975). This is the translation of the English version originally published by Chapman \& Hall (1972).

Janssen, T.: CRYSTAllograPhiC GROUPS. (N. Holland, 1973).

Kennon, N. F.: Patterns in CRystals. (Wiley, 1978). A rather unclear presentation, of an unusual style. Review in A36, 500 .

Klemm, M.: Symmetrien von Ornamenten Und KristalLEN. (Springer, 1982).

Koptsik, V. A. (Ed. by Belov, N. V.): SHUBNIKOV GroupS ['BLACK-AND-WHITE' GROUPS]: A REFERENCE MONOGRAPH ON THE SYMMETRY AND PHYSICAL PROPERTIES OF CRYSTAL Structures. (in Russian). (Moscow Univ. Press, 1966). A few copies are now available from The Executive Secretary, IUCr, 5 Abbey Square, Chester CH1 2HU, England.

Locher, J. L. et al.: Die Welten des M. C. Escher. (Moos Verlag, München, 1971).

Lockwood, E. H. \& Macmillan, R. H.: GeOMETRIC SYMmETRY. (CUP, 1978).

Loeb, A. L.: Colour and symmetry. (Wiley, 1971).

Loeb, A. L.: SPACE STRUCTURes: THEIR harmony AND COUNTER POINT. (Addison Wesley, 1976). A wide-ranging, quasi-philosophical book. Review in A33, 862.

MacGillavry, C. H.: Symmetry aspects of M. C. Escher's PERIODIC DRAWINGS, 2nd ed. (Reidel, 1976). Available N. America as FANTASY AND SYMMETRY (Harry Abrams).
Mamedov, Kh. S. et al:: Traditional ornamentation. (in Azerbaizhani). (Azerneshr, Baku, 1981).

Mamedov, Kh. S. et al:: Crystallographic ORNAMENTS. (in Russian). (Azerneshr, Baku, 1981).

Miller, W.: SYMmeTrY GROUPS AND THEIR APPLiCATIONS. (Academic Press, 1972).

Pearce, P.: Structure in nature is a STrategy for Design. (MIT Press, 1978). This book is more about the design of shapes, even houses, than about structure in nature. Review in A35, 510.

Pearl, R. M.: Atlas of CRystal sterfograms. (Colorado Springs, 1976).

Phillips, F. C.: Introduction to CRystallography, 4th ed. (Longman, 1971). A classic in morphological crystallography.

Rigault, G.: Simmetrie E CRISTAlli. (Editrice Loescher, Torino, 1979).

Rosen, J.: Symmetry discovered. (CUP, 1975). Symmetry in nature, life and science.

Shubnikov, A. V. \& Koptsik, V. A.: SYMMETRY IN SCIENCE AND ART. (Plenum, 1974). Reminiscent of the celebrated book by Norbert Wiener, but two or three times larger, this book is fascinating both in generality and depth.

Schumann, H.: KRISTAllgeOMETRIE. (VEB Deutscher Verlag f. Grundstoffindustrie, 1980).

Schwarzenberger, R. L. E.: N-DIMENSIONAL CRYSTALLOGRAPHY. (Pitman, 1980). Review in A37, 271.

Shafranorskii, I. I.: LECTURES ON CRYSTAL MORPHOLOGY. (Amerind, New Delhi, 1973).

Wells, A. F.: Three-dimensional NeTS AND POLYHEDRA. (Wiley, 1977). Review in B34, 2958.

Wooster, W. A.: TENSORS AND GROUP THEORY FOR THE PROPERTIES OF CR YSTALS. (OUP, 1973).

Zamorzaev, A. M.: THEORY OF SIMPLE AND MANIFOLD SYMMETRY. (in Russian). (Shtiinca, Kishinev, 1976).

Zorkii, P. M. \& Afonina, N. N.: Symmetry of molecules AND CRYSIALS. (in Russian). (Izd-vo Mosk. Univ-ta, 1979).

\section{Tabulations/Data/Bibliography}

Battle, G. C. et al. (Eds.): INTERNATIONAL DIRECTORY OF SOLID STATE MATERIALS PRODUCTION AND RESEARCH. (Research Materials Information Center, Oak Ridge, USA; 1975).

Bednowitz, A. L. (Ed.): WORLD DIRECTORY OF CRYSTALLOGRA PHERS, 6th ed. (IUCr/Reidel, 1981). This lists approx 8000 crystallographers, in 70 countries. Copies are obtainable from Reidel, Polycrystal Book Service, or national sub-editors.

Brown, I. D. et al:: BOND INDEX to THE DETERMINATION OF INORGANIC STRUCTURES (BIDICS). Vols. appear annually (Vol. 12, in 1980, covers 1977). Entries are ordered according to bond type (e.g. $\mathrm{Fe}-\mathrm{N})$ and bond length. Obtainable from the Institute of Materials Research, McMaster Univ., Hamilton, Ont., Canada L8S 4M1.

Conolly, T. F.: Ferroelectrics literature indeX. (Plenum, 1974).

Demus, D. et al.: Flüssige Kristalle in Tabellen. (VEB Deutscher Verlag f. Grundstoffindustrie, 1974).

Donnay, J. D. H. \& Ondik, H. M.: CRYSTAL daTA DETERMINATIVE TABLES, 3rd ed. Vols. 1 and 2 (1973) are essentially organic and inorganic respectively and list crystal data 
through 1966; Vols. 3 and 4 (1979), again organic and inorganic, bring the coverage up to 1974 and 1969 respectively. This compilation, totalling $\sim 45000$ entries, gives unit-cell and space-group data, plus literature reference. Produced by the International Center for Diffraction Data, Swarthmore, PA 19081, USA. Reviews of Vols. 1 and 2 in J6, 423.

Duax, W. L. \& Norton, D. A.: A tlas of Steroid structure, Vol. 1. (Plenum, 1975). Review in B33, 3273.

Hansen, J. et al.: TABles for teXture analysis of CUBIC CRYSTALS. (Springer, 1978).

Ibers, J. A. \& Hamilton, W. C. (Eds.): InTERnational TABLES FOR X-RAY CRYSTALlography, Vol. IV (REviSED aND SUPPLEMENTARY TABLES). (Kynoch Press, 1975). This and Vol. II of this definitive and centrally important compilation are now available from Reidel, Dordrecht, The Netherlands. Vols. I and III are out of print but a new totally revised and extended edition of these tables, Vol. A, SPACE-Group SYMmeTry, edited by Th. Hahn is now almost complete and will be available shortly from Reidel.

International Center for Diffraction Data: THE POWDER DIFFRACTION FILE. In book form: Sets 1-20 (organic) and 1-20 (inorganic) are currently available. (The data is alternatively available on cards, or on microfiche, or on magnetic tape.) Obtainable from the ICDD; the address is given under Donnay, above.

IUCr Commission on Crystallographic Apparatus: INDEX of CRYSTALLOGRA PHIC SUPPLIES, 3rd ed. (1972) and SUPPLEMENT (1978). Edited by Rudman, R. Obtainable from Reidel, Dordrecht, The Netherlands.

IUCr Commission on International Tables: SPACE Group AND LATTICE COMPLEXES. (National Bureau of Standards, USA, 1973). See Fisher in 28, Symmetry.

Keesee, A. M. et al. (Compilers): Crystal Growth BiblogRAPHY. (Plenum, 1979). Review in J13, 402.

Kennard, O., Allen, F. H. \& Watson, D. G.: Molecular STRUCTURES AND DIMENSIONS: GUIDE TO THE LITERATURE, 1935-1976. (1977). This large $(20 \times 30 \mathrm{~cm})$ volume, which collects four decades of crystal structures ( $\sim 16000$ items) into one set of comprehensive indexes, is a companion volume to the set of bibliographic reference books (Vols. $1-13$, so far) which are listed below. Obtainable from Reidel, Dordrecht, The Netherlands and Polycrystal Book Service, Chicago, USA. Review in B34, 3847.

Kennard, O., Watson, D. G. et al.: Molecular STructures AND DIMENSIONS, Vol. 1A: INTERATOMIC DISTANCES, 1960-65. (1973). This $20 \times 30 \mathrm{~cm}$ book covers only six years but gives considerable molecular detail, with many stereodiagrams; it is the first of a series complementary to the purely bibliographic one above. Obtainable from Reidel and Polycrystal (see above). Review in B30, 1887.

Kennard, O., Watson, D. G. et al. (Eds.): MOlecular STRUCTURES AND DIMENSIONS, Vols. 1, 2 (1970) ... Vol. 13 (1982). Fresh volumes appear annually. Currently, some 28000 compounds (i.e. full crystal structures) are listed, and this number is increasing at the rate of 3000 p.a. Compounds included are organic or organometallic only, with the exclusion of polymers. Obtainable from Reidel, Dordrecht, The Netherlands.

Landholt-Bornstein (By various editors): NUMERICAL DATA AND FUNCTIONAL RELATIONSHIPS IN SCIENCE AND TECHNOLOGY: NEW SERIES, GROUP III. Various parts of various
Vols. are published from time to time: e.g. Vol. 11 (1979) on certain physical properties; Vol. 8 (1973) on epitaxy data (Review in A31, 272); Vol. 7, in varjous parts, giving crystal structure data of inorganic compounds (Reviews in A31, 271 and 272). (Springer).

Larose, A. \& Vanderwal, J.: SCATTERING OF THERMAL NEUTRONS: A BIBLIOGRAPHY, 1932-1974. (Plenum, 1974).

Meier, W. M. \& Olson, D. H.: ATlas Of ZeOlite STRuCture TYPES. (Distributed by Polycrystal, 1978). This booklet depicts 38 selected zeolite structures in good stereopictures, fully backed by explanatory notes and bibliography.

Mighell, A. D., Ondik, H. M. el al:: CRystal data SPACE GROUP TABLES. (American Chemical Society and American Institute of Physics, 1977). These tables ( 17000 materials), based on the 3rd ed. of CRYSTAL DATA (see Donnay, above), are the successor to Nowacki's SySTEMATIC TABLES of 1967.

Mughabghab, S. F. et al: Neutron cross sections, Vol. 1, Parts A and B. (Academic Press, 1981). A voluminous compilation of data and references, this is the up-dated version of Mughabghab \& Garber's book of 1973. Vol. 2, giving neutron cross-section curves, is in preparation.

Nowacki, W.: Bibliography OF MathematiCal CRYSTALloGRAPHY. (to 1980, approx). For details of this, and the availability of copies from the IUCr, see A38, 558 or $\mathrm{J} 15,470$.

Oles, A. et al. (Eds.): MAGNETIC STRUCTURES DETERMINED BY NEUTRON DIFFraCtION. (Orpan-Export, Warsaw, 1976).

Prince, A.: Multicomponent alloy CONSTITUTION BIBLIOGRAPHY, 1955-73. (The Metals Society, London SW1Y 5DB, 1975). Review in J12, 318.

Renouprez, A. J.: DIFfusions deS RAYONS X AUX PETITS ANGLES: BIBLJOGRAPHY. (Oosthoek, 1970). Now available from Reidel, Dordrecht, The Netherlands.

Rudman, R.: INDEX OF CRYSTALLOGRAPHIC SUPPLIES, 3 rd ed. (Oosthoek, 1972). There is also a small SuPpLEMENT, dated 1978. Copies are obtainable from Reidel, Dordrecht, The Netherlands or from Polycrystal Book Service, Chicago, USA.

Saggerson, E. P.: IDEnTIFICATION TABLES for Minerals IN THIN SECTIONS. (Longman, 1975).

Smithells, C. J. \& Brandes, E. A.: Metals reference bOOK, Sth ed. (Butterworth, 1976).

Sutton, L. E. \& Truter, M. R. (Eds.): Molecular STructure BY DIFFRACTION METHODS, Vol. 6. (The Chemical Society, London, 1978). Ch. 4 of this book, written for the chemist, is a superb guide to the literature of crystal structure data.

Swanson, H. E. et al: STANDARd X-RAY DIFFRACTION POWDER PATTERNS, Section 11. (US Dept of Commerce, 1974). Review in $\mathrm{J7}, 637$.

Toropov, N. A. et al: Handbook of PhaSE diagrams of SILICATE SYSTEMS, Vols. 1 and 2. (Nauka, 1970).

Touloukian, Y. S. \& Ho, C. Y.: MASTER INDEX to MATERIals AND PROPER TIES. (Plenum, 1979). This is the index-volume of the 13-volume series by these authors, with thermophysical properties of over 6000 materials.

Trotter, J. (Ed.): STRuCtURE REPORTS. Vols. are published approximately annually; thus, Vol. $44 \mathrm{~A}$ and $\mathrm{B}$ (inorganic and organic, respectively), covering the year 1978, were published in 1980. The publisher is Reidel. Review of the most recent issues in A35, 346 (also B34, 3847). The editorship of this series is now passing to $\mathbf{G}$. Ferguson. 
Umanskij, M. M.: X-RAY Structure analysis: a BiblioGRAPHY, 1960-1975. (in Russian). (Leningrad Scientific Publ. Co., 1978). This compilation includes very few textbooks later than 1970; however, it lists many papers and articles, including many published in 1970-1975. Further comment in A35, 510.

Watson, D. G.: Crystallography: chapter 1 of the Codata Directory of Data SOURCES for SCIENCE AND TeCh-
NOLOGY. (Codata, 51 Boulevard de Montmorency, 75016, Paris, 1977). This is a most systematic and detailed document, listing laboratories, and other bodies, worldwide, which are compiling data-banks, bibliographies, etc. on proteinis, liquid crystals, alloys, minerals, etc., etc. Ch. 1 of this Directory (also called CoData Bulletin No. 24) is obtainable separately from the Paris address given above.
Abbott, E. A.

Abrahams, S. C.

Achenbach, J. D.

Adamczyk, A.

Adams, D. M.

Afonina, N. N.

Agarwal, B. K.

Agranovich, V. M.

Ahmed, F. R.

Albany, J. H.

Alcacer, L.

Aleksandrov, L. N.

Aleshin, V. G.

Alexander, L. E.

Allen, F. $\mathrm{H}$.

Allen, G.

Alper, A. M.

Altmann, $\mathrm{S}$.

Amelinckx, $\mathrm{S}$.

Am. Soc. Metals

Amigó, J. M.

Amorós, J. L.

Anderson, J. C

André, J.-M.

Andrews, K. W.

Angress, J. F.

Animalu, A. O. E.

Arem, J. E.

Arkhipenko, D. K.

Armstrong, R. D.

Arndt, U. W.

Arnold, $\mathrm{H}$

Arsen'ev, P. A.

Ash, E. A.

Ashcroft, N. W.

Assoc. Univ. Radiation

Protection Off. (UK)

Aubert, G.

Auluck, F. C.

Authier, A.

Azaroff, L. V.

Backhaus, K.-O.

Bacon, G. E.

Balaban, $M$.

Balian, R.

Balkanski, M.

Bambauer, H. U.

\section{Author Index}

Numerals given refer to section numbers

Bancroft, P. $\quad 17$

Bank, $\mathrm{H}$.

Baracki, A.

Barber, M. S

Bardsley, W.

Bariand, $P$.

Barišič, S.

Barnes, A. J.

Barrer, R. M.

Barrett, C. S.

Barrow, R. F.

Bartolo, B. D.

Bassani, G. F.

Bassett, D. C.

Bata, L.

Battey, M. H.

Battista, O.A.

Battle, G. C.

Bautsch, H.-J.

Bazarov, J. P.

Beck, H.

Becker, P.

Bednowitz, A. L.

Bedyńska, T.

Beeforth, T. H.

Behrisch, R.

Belk, J. A.

Belov, N. V.

Beneking, $\mathrm{H}$.

Bernal, I.

Bernal, J. D.

Bernasconi, J.

Bernshtejn, M. L.

Bernstein, $\mathrm{H}$.

Berry, B. S.

Bertaut, E. F.

Bertin, E. P.

Bethge, $\mathrm{H}$.

Beyer, $\mathrm{H}$.

4, 5 Bhide, V. G.

4, 9 Bijvoet, J. M.

Blakely, J. M.

18 Blakemore, J. S.

20, 25, $26 \quad$ Blinc, R.

18, 24 Blom, G. M.

Bloss, F. D.

Blumstein, A.

Blundell, T. L.

17,21
Blythe, A. R.

23

17

Boardman, A. D.

Bobeck, A. H.

Bogdanow, R. W.

28

18

1, 26

17

Bohm, J.

Bojarski, Z.

Bok, J.

Bokii, G. B.

Bold, T.

Bolewski, A.

Bollmann, W.

Bonatti, S.

Bond, W. L.

Bonse, U.

Booth, A. R.

Booth, G.

Bootsma, G. A.

Borchardt-Ott, W.

Borisova, $Z$.

Born, E.

Borsdorf, R.

Bourdon, J.

Bourgoin, J.

Bowen, D. K

Bowkett, K. M.

Bradley, C. J.

Bragg, W. L.

Brand, J. C. D.

Brandes, E. A.

Brauns, R.

Bravais, A.

Brederoo, P.

Bretton, A.

Brice, J. C.

Brindley, G. W.

Brodin, M. S.

Brodsky, M. H.

Brostow, W.

Brown, D. B.

Brown, $\mathrm{G}$.

Brown, G. H.

Brown, $\mathrm{H}$.

Brown, I. D.

Brown, J. G.

Brown, M. A.

Brown, P. J.

Bruce, A. D.

Brüesch, P.
18

26

1,7

$9,18,26$

12

25

9

17

3

17

18

2,20

28

11

27

7,26

12

3

28

1,27

12,28

3,6

28

8

19

29

17

8

2,11

1

17

2

1,26

25

17

10

28

29

7

26

7,25

22 
Brümmer, $\mathrm{O}$.

Brundle, C. R.

Bube, R. H.

Buckingham, A. D.

Buckingham, J.

Buerger, M. J.

Bugakov, V. Z

Bulak, L. N.

Bullen, G. J.

Burfoot, J. C.

Burgers, W. G.

Burkhanov, G. S.

Burke, E. A. J.

Burke, J. J.

Burns, G.

Burns, R. G.

Burstein, E.

Burton, B.

Burton, J. J.

Burzlaff, $\mathrm{H}$.

Busch, G.

Butler, P. H.

Cachard, A.

Caglioti, G.

Cairns-Smith, A. G.

Califano, S.

Callaway, $\mathbf{J}$.

Caplin, A. D

Caroe, G. M.

Carroll, J. E.

Carter, G.

Cartmell, E.

Casasent, D.

Celotti, G.

Céolin, $\mathrm{R}$.

Chadderton, L. T.

Chadwick, G. A.

Chakraverty, A. S.

Chanda, M.

Chandra, S.

Chandrasekhar, S.

Chaudhari, P.

Chem. Soc. Japan

Chen, C.-W.

Chernov, A. A.

Chesney, D. N.

Chesney, M. O.

Chojnacki, J.

Christian, J. W.

Chudoba, K. F.

Ciardelli, F.

CIBA

Clark, G. M.

Clarke, M. J.

Clarke, P. T.

Close, K. J.

Cochran, W.

Cohen, J. B.

Coleman, R. V.

Coles, B. R.

Collins, T. C.
Colombo, U.

Conolly, T. F.

Cotterill, P.

Coulomb, P.

Courtel, R. J.

7, 26, 28 Coutts, T.

Cowley, J. M.

Cowley, R. A.

19, 26 Cox, K. G.

Cracknell, A. P.

Crangle, J.

Cross, L. E.

Crow, J. E.

Cullen, G. W.

Cullis, A. G.

Cullity, B. D.

Curien, $\mathrm{H}$.

Cyvin, S. J.

Dachs, $\mathrm{H}$.

Dalven, R.

Damask, A. C.

Davenport, A. T.

Davidge, R. W.

Davies, G. J.

Davis, E. A.

Dawber, P. G.

Dawson, B.

Day, D. E.

Dearnaley, G.

De Batist, $R$.

Decius, J. C.

Deer, W. A.

Delepine, C.

Della Torre, E.

Demus, D.

1, 2, 18 Dent Glasser, L.S.

Deren், J.

Devreese, J. T.

Diamond, $\mathbf{R}$.

Dienes, G. J.

11, 18 Dmitriev, I. S.

Dobler, M.

Dobson, P. J.

Dodson, $G$.

Doherty, R. D.

Domb, C.

Donaldson, J. D.

Doniach, S.

Donnay, J. D. H.

Donohue, $\mathbf{J}$.

Donovan, B.

Dorain, P. B.

Dorner, B.

Dreyer, W.

19,25

Duax, W. L.

12,26

Ducros, P.

7, 11 Dugdale, J. S.

2 Dunitz, J. D.

2, 12 Dupuy, C. H. S.

18

Durski, Z.
12

$12,18,29$

9
18

9,18

27

12

$2,4,5$

22

17

2, 28

2

22

2

$1,12,27$

12

$7,9,11,26$

26

2,19

20

12

9

28

11

11

2

28

4

27

2, 3

3

2

17

26

18

10,29

7,26

25

2,14

15

9

28

19

5

19,24

9

2,22

28

18

28,29

25

2

$25,26,28$

2, 20

11,17

19,29

26

2

$7,19,25$

27
Eastman, L. F.

12

Eberhart, J.-P.

Edington, J. W.

17

Egert, E.

Eitel, W.

Elliott, J. P.

Elliott, R. J.

Elwell, D.

Emons, H.-H.

Enderby, J. E.

Engels, F.

Englman, R.

Epifanov, G.

Epstein, A. J.

Ertl, G.

Eschenfelder, A. H.

Evans, C. C.

Evans, R. C.

Ewald, P. P.

Eyring, L.

6

26

11

28

2

1,18

21

18

26

18

2

14

27

18

2, 18

25
8

3,18

Fair, H. D.

Faktor, M. M.

Farge, Y.

Fava, R. A.

Fedorov, E. S.

Feldmann, R.

Feneau-Dupont, J.

Ferguson, $\mathbf{G}$.

Fermi, G.

Ferry, D. K.

Field, J. E.

Figielski, T.

Finkel, V. A.

Finniston, H. M.

Fisher, W.

Fitzsimons, D. W.

Fletcher, G. C.

Flurry, R. L.

Flynn, C. P.

Fonash, S. J.

Font Altaba, M.

Fontana, M. P.

Forsyth, J. B.

Fradin, F. Y.

Frank-Kamenetskij, V. A.

Franks, F.

Franzini, M

Fraser, D. A.

Freeman, A. J.

French, A. D.

French, P. M.

Freyhardt, H. C.

Fridkin, V. M.

Fujita, E.

Fumi, F. G.

Furrer, A.

Gabis, V.

Gait, R. I.

Galasso, F. S.

Gałdecki, Z.

25

1

33
28

28

24

$7,25,26$

7,29

24

12

18

3

, 11

28

24

2

18

17

3

7,25

11

9, 17

25

17

12

2 
Gamarnik, M. J.

Garber, D.

Gard, J. A.

Gardner, K. H.

Garner, C. D.

Garrett, I.

Garrido, J.

Gautschi, G. H.

Gay, P.

Geballe, T. H.

Gedcke, D.

Geguzin, J. E.

Gehlen, P. C.

Geil, P. H.

Geller, S.

Gennes, P. G. de

Geus, J. W.

Ghatak, A. K.

Giacovazzo, C.

Gibson, A. F.

Gilinskaya, E. A.

Gimarc, B. M.

Ginzburg, V. L.

Girault, J.

Gittus, J.

Giusti, P.

Gladyshevskii, E. J.

Glass, A. M.

Glatter, O.

Glauert, A. M.

Glazer, A. M.

Gleiter, $\mathrm{H}$.

Glocker, R.

Glusker, J. P.

Goldsmid, H. J.

Goldstein, J.

Golovin, S. A.

Gonser, U.

Goodby, J. W.

Goodman, C. H. L.

Goodman, P.

Gool, W. van

Gorczycz, S.

Gorelik, S.

Goringe, M. J.

Gorjunowa, N. A.

Goshchitskii, B. N.

Gottstein, G.

Götz, J.

Gould, R. W.

Grabmaier, J.

Grabmaier, J. G.

Gramaccioli, C. M.

Grant, W. A.

Gray, G. W.

Graziosi, G.

Green, M. S.

Greenslade, D. J.

Greenwood, N. N.

Griffen, D. T.

Groves, G. W.

Gruber, B.
18 Grundy, P. J.

20, 29 Gruverman, I. J.

Gschneider, K. A.

Gübelin, E. J.

Guinier, A.

Guldberg, J.

Guntherodt, H. J.

Guy, A. G.

Guzik, Z.

2,18

9 Habermehl, G.

2, 3 Haessner, F.

3 Hägg, G.

23 Hall, $C$.

13 Hall, C. R.

10 Hall, H. E.

27 Hallimond, A. F.

Hamakawa, Y.

Hamilton, W. C.

Hannay, N. B.

Hansen, J.

Harburn, G.

Hardy, J. R.

Hargittai, I.

Harker, D.

Harker, K.

Harrison, W. A.

Harsch, G.

Hart-Davis, A.

Hartman, P.

11, 22, 26, 28 Hartshorne, N. H.

Hasiguti, R. R.

Hatfield, W. E.

7, 8, 19, 24, $26 \quad$ Hatz, $\mathbf{R}$.

Haug, A.

Hauptman, H. A.

Haussühl, S.

Hawkes, P. W.

Hawkins, D. T.

Hayes, W.

5, 8 Head, A. K.

Health \& Safety Exec.

Hearle, J. W. S.

Heimann, R. B.

Heinz, K.

Helfrich, W.

Hellner, E.

Hellwege, K. H.

Hemmerich, $\mathbf{P}$.

Henderson, $\mathbf{B}$.

$1,11,12$ Henisch, H. K.

Heppke, G.

Herman, F.

Herrmann, R.

Hexter, R. M.

Heydenreich, J.

2, 22 Heymann, $P$.

19, 26 Heywang, $H$.

Hilsum, C.

Hintze, C.

Hinz, W.

Hirsch, P. B.
Hirshfeld, F. L.

4, 19

Hirth, J. P.

Hittmair, $\mathrm{O}$.

Ho, C. Y.

11,18

Hobbs, P. B.

11,29

Hodgkin, D. C.

2

Höhler, $\mathrm{G}$.

Holden, A. 28

Hollas, J. M. 28

Holt, S. L. 25

Hölzl, J. 27

Honeycombe, R. W. K. 9

Hoppe, W. $\quad 4,5,6,16,18,19$

Hornbogen, E.

6,11

Horton, G. K.

2

Hosemann, R. 18

Hoshino, S. 20

$\begin{array}{rlr}15,28,29 & \text { Howie, R. A. } & 17 \\ 12,25 & \text { HSE (UK) } & 18\end{array}$

29 Hudson, M. 7, 26

26 Hughes, A. E.

2 Hukins, D. W. L. 4, 26

4 Hull, D. 11,25

28 Hulliger, F. $\quad 12$

2, 25 Huppmann, W. J. 11

26 Hurlburt, C. S.

2, 26 Hwang, W. 11, 12

$\begin{aligned} 1 & \text { IAEA } 3,11,20,27\end{aligned}$

12 Ibach, $\mathrm{H}$. 27

14 Ibers, J. A. 19, 25, 29

10 Ikornikova, N. J.

2 Int. Center Diff. Data 29

16 IUCr Comm. Apparatus 29

7, 28 IUCr Comm. Int. Tables 29

IUCr Comm. Cryst. Teaching 26

Ivanovov, L. I.

Ivernova, V. I. $\quad 2$

Izyumov, Y. A. $\quad 20$

Jain, S. C.

Jančić, S. J.

Janssen, $T$.

Jeffery, J. W.

Jeleńkowski, J.

Jenkins, R.

Jensen, L. H.

Jeu, W. H. de

Johan, $\mathrm{Z}$.

Johari, $\mathrm{O}$.

John, V. B.

Johnson, J. F.

Johnson, L. N.

Jones, G. A.

Jones, $\mathrm{H}$.

Jones, $\mathrm{W}$.

Jong, E. J. de

Jost, K.-H.

Joy, D. C.

Julg, A.

18
9
28
7
26
9

$7,16,26$

10

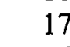

17
6

22

10

24

2

2
9

7,26

12,18

26 
Juretschke, H. J.

Kabaieva, V. M.

Kachanov, L. M.

Kahan, Th.

Kakudo, M.

Kaldis, E.

Kallard, T.

Kalokerinos, A.

Kaluski, Z.

Kambe, $K$.

Kaminskii, A. A.

Kane, P. F.

Kao, K.-C.

Karo, A. M.

Kasai, N.

Kato, N.

Katsnel'son, A. A.

Kauczor, E.

Kaufmann, E. N.

Kaufman, L.

Kazmerski, L. L.

Keesee, A. M.

Kelker, $\mathrm{H}$.

Kell, J. C.

Keller, E.

Keller, H. J.

Keller, S. P.

Keller, W.

Kelly, A.

Kelly, B. T.

Kennard, $\mathrm{O}$.

Kennon, N. F.

Kepert, D. L.

Kheiker, D. M.

Khetrapal, C. L.

Kihlborg, L.

Kimura, $\mathrm{H}$.

King, D. A

Kirzhnits, D. A.

Kitagawa, T.

Kitaigorodskii, A. I.

Kittel, C.

Kleber, I.

Kleber, W.

Klein, M. L.

Kléman, $M$.

Klemm, M.

Klug, H. P.

Klyne, W.

Kofstad, P.

Kolkert, W. J.

Komjak, N. I.

Komov, I. L.

Konakov, P. K.

Koptsik, V. $\dot{A}$.

Kornder, F.

Kornilov, N. I.

Kosevich, V. M.

Kostorz, G.

Kosturkiewicz, Z.

Kothari, L. S.
2

$$
\begin{aligned}
& \text { Kozlova, O. G. } \\
& \text { Kratky, O. } \\
& \text { Krebs, H. } \\
& \text { Kressel, H. }
\end{aligned}
$$

Kovács, I.

$7,23,26$

$1,11,12$

Krischner, $\mathrm{H}$

Krishnan, R. S.

Krishtal, M. A.

Krivoglaz, M. A.

Kröger, F. A.

Kubiak, R.

Kubisz, J.

Kuntsevič, I. M.

Kunz, C.

Küppers, J.

Kushta, G. P.

Kuz'min, E. A.

Kuznetsov, T. A.

Labes, M. M.

Lachowitz, $\mathrm{H}$.

Ladd, M. F. C.

Ladik, J.

Ladurner, J.

Lajzerowicz-Bonneteau, $\mathbf{J}$.

Lakhtin, Yu.

2,14

Landholt-Bornstein

Lang, S. B.

Lannoo, M.

3,11

Lantanision, R. M.

Larose, A.

Larrabee, G. B.

Larson, M. A.

Laudise, R. A.

Lawn, B. R.

Lazarenko, E. K.

Lee, $P$.

9, 11 Lefever, R. A.

Lefkowitz, I.

Legendre, B.

Lehmann, C.

Lekhnitsky, S.

Lemmlein, G. G.

Lenz, D.

Leteurtre, J.

Leuschner, D.

Levin, A. A.

Lévy, F.

Lide, D. R.

Liebau, F.

Lieber, W.

Liebert, L.

Lieth, R. M. A

Lindner, H. J.

Lines, M. E.

Lippmann, $\mathbf{F}$.

Lipson, H. $4,5,7,8,9,16,18,22$,

Litvinskaja, G. P.

Lobachev, A. N.

Locher, J. L.

Lockwood, E. H.

3
1,26

18

25

12,27

2,11

,

2, 3

$1,2,18,22$

26

15

18

27

26

16

12

10

18

$7,16,25$

2
17

26

9,11

29

18

12

27

20,29

27

18

1

18

11

1

18,23

22

3

2

1

2

18

26

12

11,25

19

17

7

10

11,25

26

12

17

25

3,6

2
Loeb, A. L.

Loretto, M. H.

28

Lothe, J.

Lovesey, S. W.

3,6

Lovett, D. R.

2,20

2,12

2,11

Luckhurst, G. R.

Ludwig, W.

Luger, $\mathrm{P}$.

10

7,26

McCarthy, G. J. $\quad 9,18$

McColl, J. L. 27

McConnell, D. 17, 18

MacCrone, R. K. 11

McCrone, W. C. 21

MacGillavry, C. H. 28

MacKenzie, W. S. 17

McKie, C

$7,25,26$

McKie, D. 7, 25, 26

McLachlan, D.

McMillan, F. M.

Macmillan, R. H.

McMurdie, H. F.

McPherson, A.

Maddin, R.

Madelung, $\mathrm{O}$.

Mahan, G. D.

Maleev, M. N.

Malinovskii, T. I.

Mamedov, Kh. S.

Mannami, $M$.

Manning, J. R.

Maradudin, A. A.

March, N. H.

Marfunin, A. S.

Maris, H. J.

Marmasse, $\mathrm{C}$.

Marshall, R. C.

Marshall, W.

Martin, J. W.

Mason, $\mathbf{R}$.

Massalski, T. B.

Mathieu, J. P.

Matkovich, V. I.

Mátrai, M.

Matthews, J. W.

Matveeva, N. A.

Megaw, H. D.

Meier, G.

8
23

28

9

24

9,11

2

13

1

25

28

7

2

2

7. 18

Meier, W. M.

Melankholin, N. M.

Melson, G. A.

Mermin, N. D.

Metzger, R. M.

Meyer, $\mathbf{K}$.

Meyer, $\mathbf{O}$.

Michel, $\mathrm{K}$

Mighell, A. D.

Milburn, G. H. W.

Miller, J. S.

Miller, R. L. 
Miller, W.

Millman, R. S.

Mirkin, L. I.

Miravitlles, L.

Misell, D. L.

Mitra, S.

Mitsui, T.

Moffatt, W. G.

Molière, K.

Mongiorgi, R.

Moore, T. M.

Morgan, A. R.

Morse, S. A.

Mortier, W. J.

Moss, T. S.

Mott, N.

Mould, P. R.

Mrowec, S.

Mughabghab, S. F.

Mühlbauer, A.

Muir, L. E.

Müller, K. A.

Muller, $\mathrm{O}$.

Mullin, J. B.

Mullin, J. W.

Mulvey, T.

Mumpton, F. A.

Murphy, W. F.

Musgrave, M. J. P.

Nabarro, F. R. N.

Nag, B. R.

Nagakura, $S$.

Nancollas, G. H.

Narasimhamurty, T. S.

Narayan, J.

Náráy-Szabo, G.

Nassau, K.

Navrotsky, A.

Nechvolod, N. K.

Nedoma, $\mathrm{J}$.

Neidle, $S$.

Neilson, G. W.

Nemoshkalenko, V. V.

Neumann, G.

Neumann, G. M.

Newman, R. C.

Newnham, R. E.

Nicholas, A.

Nickel, E.

Nishiyama, Z.

Nishizawa, J.

Nitsche, R.

Nixon, W. C.

North, A. C. T.

Norton, D. A.

Nowacki, W.

Nowick, A. S.

Nyvlt, J.

Obłakowski, J.

O'Dell, T. H.
Ogawa, T.

Ohara, M.

O'Keeffe, M.

Olejnik, S.

Oles, A.

Olson, D. H.

Omar, M. A.

Ondar, J.

Ondik, H. M.

Oostrom, A. G. L. van

Ormont, B. F.

Orville-Thomas, W. J.

Ovsienko, D. E.

Ozerov, R. P.

Palatnik, L. S.

Palmer, R. A.

Pamplin, B. R.

20, 29 Parfianovich, I. A.

Parker, R. L.

Parrinello, $M$.

Parsonage, N. G.

Parsons, D. F.

Parthasarathy, S.

Parthé, E.

Pastori, P. G.

Pattabhi, V.

Paufler, $P$.

Paul, G.

Paul, M. A.

Paul, W.

Pawłowski, K.

Pearce, $P$.

Pearce, S.

Pearl, R. M.

Pearson, W. B.

Pellegrini, C.

Pendry, J. B.

Penkala, $\Upsilon$.

Penzina, E. E.

Perutz, $M$.

Petzow, G.

Phillips, D. C.

Phillips, F. C.

Phillips, J. C.

Phillips, W. R.

Picot, P.

Pietronero, $\mathrm{L}$.

Pinsker, Z. G.

Pistorius, C. W. F. T.

Platenko, J. A.

Platonov, G. L.

Plyusnina, I. I.

Poirier, J. P.

Pooley, D.

Porter, R.

19,29

15,29

Porter, R. S.

Poulet, $\mathrm{H}$.

Povarennykh, A. S.

Predvoditelov, A. A.

Preppernau, U.

Press, W.

\begin{tabular}{|c|c|c|}
\hline 2 & Preuss, E. & 18 \\
\hline 1 & Priestley, E. B. & 10 \\
\hline 3,25 & Prince, A. & 29 \\
\hline 2,9 & Prince, E. & 15 \\
\hline 20,29 & Prutton, M. & 27 \\
\hline 17,29 & Pryor, A. W. & 2 \\
\hline 2 & Purtscheller, F. & 17 \\
\hline 27 & & \\
\hline 29 & Queisser, H.-J. & \\
\hline 27 & Quéré, V. & 18 \\
\hline 12 & Quian, T. F. J. & \\
\hline 4,19 & & \\
\hline 3 & Raaz, F. & \\
\hline 20 & Rabenau, A. & $\begin{array}{r}25 \\
2\end{array}$ \\
\hline & Rabii, S. & \\
\hline 6 & Raghavan, V. & 11 \\
\hline 7,16 & Rao, C. N. R. & 2,22 \\
\hline 1,12 & Rao, E. C. S. & 11 \\
\hline 3 & Rao, K. J. & 2,22 \\
\hline 1,17 & Ramachandran, G. N. & 15 \\
\hline 2 & Ramaseshan, S. & 4,15 \\
\hline 3 & Ramdohr, P. & 17 \\
\hline 18 & Randolph, A. D. & 18 \\
\hline 15 & Ransom, J. E. & 17 \\
\hline 25 & Rashba, E. & \\
\hline 2 & Ratajczak, H. & 15 \\
\hline 24 & Rauch, H. & 20 \\
\hline$, 22,26$ & Rauluszkiewicz, J. & 12 \\
\hline 3 & Ravi, K. V. & 1 \\
\hline 19 & Read, P. G. & 1 \\
\hline 12 & Rebane, K. K. & \\
\hline 9 & Reed, S. J. B. & 2 \\
\hline 18,28 & Reid, R. C. & \\
\hline 18 & Renouprez, A. J. & 2 \\
\hline 28 & Reynolds, C. & \\
\hline 7,9 & Rhodin, T. N. & 2 \\
\hline 18 & Ricci, J. S. & \\
\hline 5,27 & Richards, F. M. & \\
\hline 26 & Richardson, J. H. & \\
\hline 3 & Richter, L. & \\
\hline 24 & Ridley, B. K. & \\
\hline
\end{tabular}

$7,26,28$

$\begin{array}{rlr}8,24,26 & \text { Riste, T. } & 2,22 \\ 28 & \text { Roberts, I. F. } & 25,26\end{array}$

Roberts, M. W. 27

$\begin{array}{rlr}17,21 & \text { Roberts, W. L. } & 17 \\ 17 & \text { Robertson, J. M. } & 7,19,25\end{array}$

Robson, P. N. 12

Rooijmans, C. J. M. $\quad 1,11,25$

Rosen, I. C. 28

Rosenberg, H. M. 2

Rosenberger, $\mathrm{F}$.

$11,12,27$

Rösler, H.-J.

Ross, S. D.

Rossmann, M. G

Roth, W. 13

Rousseau, R. W. 1

Roy, R. 25

Roy. Soc. London 24

Rudman, R. $\quad 18,29$

Rykart, R.

Rymer, T. B.
8

4

18

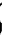

20


Sackmann, E.

Saeva, F. D.

Saggerson, E. P.

Saito, Y.

Salamon, M. B.

Salli, I. V.

Samsonov, G. V.

Samuels, R. J.

Sand, L. B.

Sands, D. E.

Sarma, R. H.

Sasada, Y.

Savitskii, E. M.

Sayre, D.

Schade, H.

Schatt, W.

Scheel, H. J.

Scheer, L.

Schenk, H.

Schieber, M.

Schlenker, B. R.

Schlenker, $\mathrm{M}$.

Schmalzried, $\mathrm{H}$.

Schmid, H.

Schmidt, R.

Schneer, C. J.

Schneider, H. G.

Schneider, $\mathrm{T}$.

Schröcke, H.

Schubert, K.

Schülter, M.

Schultz, J. M.

Schultze, G. E. R.

Schumann, H.

Schuster, P.

Schwartz, L. H.

Schwarzenberger, R. L. E.

Seddon, K. R.

Seidel, C. W.

Seifert, $\mathrm{H}$.

Seim, R.

Seitz, F.

Seltzer, M. S.

Selzer, P. M.

Senczyk. D.

Senechal, M

Seraphin, B. O.

Shafranovskii, I. I. 1, $1,17,28$

Shapiro, C. M.

Shaskol'skaya, M. P.

Shay, J. L.

Sheftal, N. N.

Shelley, D.

Shenoy, G. K.

Sherwood, D.

Sherwood, J. N.

Sherwood, P. M. A.

Shubnikov, A. V.

Shuvalov, L. A.

Shvarts, K. K.

Sidorov, S. K.

Silinsh, E. A.
Sim, G. A.

Simmons, G.

17, 29 Sinha, S. K.

25, 26 Sirota, D.

Sirota, N. N.

Sirotin, $\mathrm{Yu}$.

Skobel'tsyn, D. V.

Skrzat, Z.

Slater, J. C.

7, 10, 26 Slesareva, N. V.

24 Smallman, R. E.

7, 26 Smith, D. A.

Smith, D. K.

19,24

Smith, G. F. H.

Smith, J. V.

Smith, P. A.

Smithells, C. J.

Smoluchowski, R.

Somorjai, G. A.

Sonin, A. S.

Sørensen, O. T.

Sorin, L. A.

Sowerby, D. B.

Sparnaay, M. J.

Sparrow, J. T.

8, 18 Speakman, J. C.

Spence, J. C. H.

Sprackling, M. T.

Sprockel, G. J.

18,25 Squire, J.

2, 11 Squires, G. L.

$4,11,23,26 \quad$ Srinivasan, $R$.

$2,9,11$ Srivastava, O. N.

7, 9, 21, 28 Stanley, H. E.

19,25

7,11

Startsev, V. I.

Stark, J. P.

Staveley, L. A. K.

Steadman, R.

Steeds, J. W.

Steeple, H.

Stegemeyer, $\mathrm{H}$.

Stephanik, $\mathrm{H}$.

Stevens, J. G.

Stiddard, M. H. B.

Stoiber, R. E.

Stolz, H.

Stoneham, A. M.

Stout, G. H.

Strechnikov, V. N.

$2,7,11,26$

Street, R. A.

Strens, R. G. J.

Strübel, G.

17, 21 Strugalski, Z.

11, 18 Strunz, H.

7, 24 Stuart, A.

Sturge, M. D.

Stüwe, H. P.

Subbarao, E. C.

7,26 Subramanian, E.

Suchet, J. P.

Suematsu, Y.

Sugano, $\mathrm{T}$.
Sutton, L. E.

Suzuki, H.

19,29

Svechnikov, V. N.

Swalin, R. A.

2,25

Swanson, H. E.

2,7

Switzer, G. S.

Symons, M. C. R.

Sze, $\mathrm{S}$.

Szigeti, G.

Takeuchi, Y.

3,6

1,18

Tau, T. Y.

Tanner, B. K.

Tarján, I.

17, 26 Taylor, C. A.

Taylor, G.

Taylor, G. W.

Teo, B. K.

Teodosin, C.

Thim, H. W.

Thomas, $\mathbf{H}$.

Thomas, J. M.

Thomas, L. A.

Tichý, J.

Timmerhaus, K. D

19,26

Todd, C. J.

Tollenaere, J. P.

2, 11

Tomashpoisky, Yu. Ya.

Tong, S. Y.

Toropov, N. A

Tosatti, E.

$7,15,24$

Touloukian, Y. S.

Townsend, P. D.

2, 22 Townsend, R. P.

Trefilov, V. I.

Tröger, W. E.

Troickij, O. A.

Trotter, J.

Trueblood, K. N.

Truter, M. R.

Tryde, $P$.

Tuchkevich, V. M.

Turner, E.

Turrell, G.

Tyler, J. K.

2,3

$18,21,26$

18,23

18

$11,12,27$

27

26,29

11,29

17,21

7,26

19,29

2

Ubbelohde, A. R.

18

$7,16,26$

Udowski, H.-E.

Ueda, $R$.

Umanskij, M. M.

Uytenbogaardt, W.

7,29

Vainshtein, B. K.

7,26

Vanderwal, J.

20,29

Van Hove, M. A.

Van Meersche, $M$.

$7,25,26$

Vashista, P. D.

Vasilavskaia, A. S.

Vavrinecz, $G$.

18

Venables, J. A.

2, 6

Venkatamaran, G.

Venkatesan, $\mathrm{K}$. 
Verma, A. R.

Vértes, A.

Vibrans, G.

Vigdorovič, V. N.

Villars, F. M. H.

Vinogradov, A. P.

Vinokurov, V. M.

Vladimirov, V. I.

Vlasov, A. G.

Vlasova, M. V.

Vogel, W.

Vonsovsky, S. V.

Vries, J. L. de

Vynar, O. N.

Wagner, R.

Wahlstrom, E. E.

Walker, J. J.

Walker, R. F.

Wallace, D. C.

Walton, A.

Wang, C. C.

Wang, F. F. Y.

Wang, $\mathrm{H}$.

Warlimont, J. H.

Warlimont, $\mathrm{H}$.

Watson, D. G.

Watson, J. D.

Watts, R. K.

Weber, H. W.

Weibel, $\mathrm{M}$.

Weigel, D.

Weiner, K.-L.

Weiss, $\mathrm{H}$.
Weiss, V.

Weissmantel, C.

Wells, A. F.

Wenk, H. R.

Wernick, J. H.

Wertheim, G. K.

Wertz, J. E.

2, 3, $26 \quad$ Wesołowski, K.

White, R. M.

Whitehouse, J. E.

11, 18 Whittaker, E. J. W.

18 Wiener, N.

9 Wieting, T.J.

18 Wilcox, W. R.

Wilke, K.-T.

Wilkes, P.

Williams, A.

Williams, $F$

Williams, R. J. P.

Willis, B. T. M.

$18,19,25$ Wilson, A. J. C.

12 Wilson, B. L. H.

11,12 Windle, A.

Windsor, C. G.

Winick, $\mathrm{H}$.

Winsor, P. A.

19, 29 Wohlfarth, E. P.

Wolfe, C. M.

Wölfel, E. R.

11, 18 Wood, E. A.

17

7,26

Wood, J.

Wood, W. A

Woodhead-Galloway, J.

12 Woodruff, D. P.

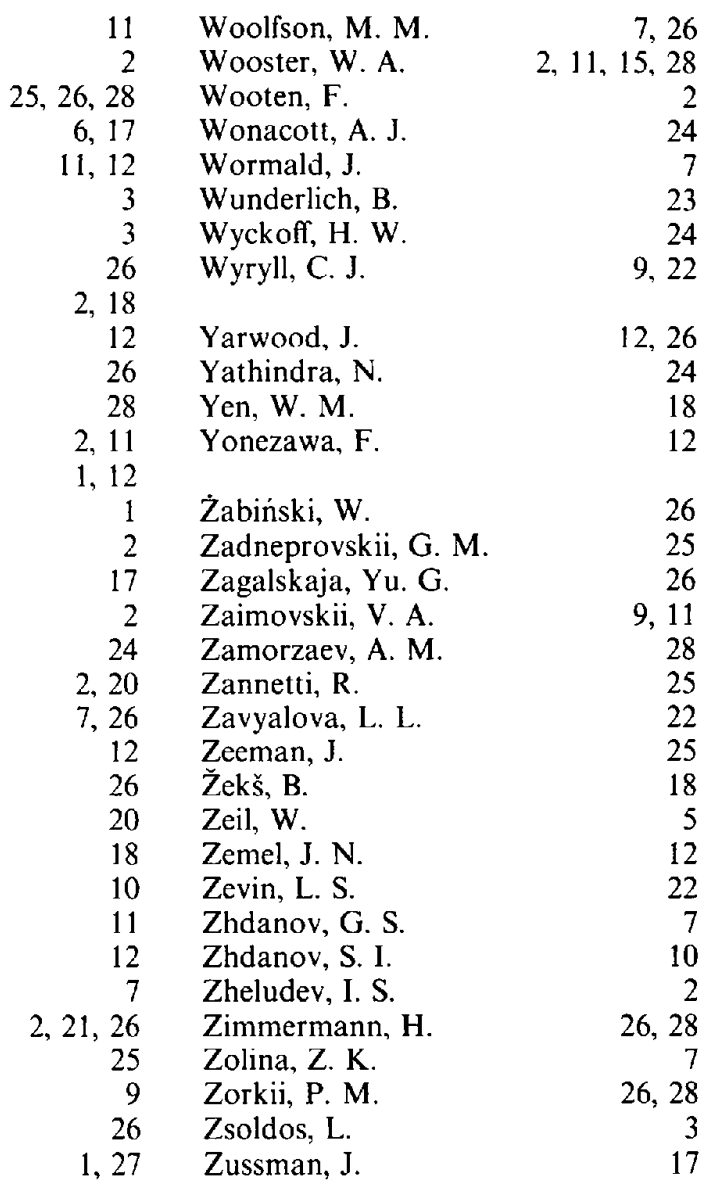

